Portland State University

PDXScholar

\title{
Erasing the Space Between Japanese and American: Progressivism, Nationalism, and Japanese American Resettlement in Portland, Oregon, 1945-1948
}

Robert Alan Hegwood

Portland State University

Follow this and additional works at: https://pdxscholar.library.pdx.edu/open_access_etds Let us know how access to this document benefits you.

\section{Recommended Citation}

Hegwood, Robert Alan, "Erasing the Space Between Japanese and American: Progressivism, Nationalism, and Japanese American Resettlement in Portland, Oregon, 1945-1948" (2011). Dissertations and Theses. Paper 151.

https://doi.org/10.15760/etd.151

This Thesis is brought to you for free and open access. It has been accepted for inclusion in Dissertations and Theses by an authorized administrator of PDXScholar. Please contact us if we can make this document more accessible: pdxscholar@pdx.edu. 
Erasing the Space Between Japanese and American:

Progressivism, Nationalism, and Japanese American Resettlement

in Portland, Oregon, 1945-1948

by

Robert Alan Hegwood

A thesis submitted in partial fulfillment of the

requirements for the degree of

\section{Master of Arts}

in

History

Thesis Committee:

Kenneth J. Ruoff, Chair

Katrine Barber

David A. Johnson

Hillary Jenks

Portland State University

(C)2011 


\section{ABSTRACT}

This study examines the return of Japanese Americans to Portland, Oregon, following their mass incarceration by the United States Federal government between 1942 and 1945. This essay examines the motivations of both returning Japanese Americans and various groups within the white community with equal focus in the hopes of writing a history that provides agency to both groups. The return of Japanese Americans to Portland was an event with broader implications than a mere chapter in the history of Japanese Americans.

The rise of the Japanese Exclusion League and other groups interested in preventing the return of Japanese Americans to Oregon had their roots partly in the Oregon progressive coalition of the 1930s known as the Oregon Commonwealth Federation (OCF). Unified behind the cause of public ownership of electricity distribution, racially exclusive progressives such as Oregon Governor Walter M. Pierce and civil rights progressives such as American Civil Liberties Union lawyer Gus J. Solomon sought to protect Oregon's producer class of farmers and workers from exploitation by Portland business interests. After the dissolution of the OCF in 1940 and the attack on Pearl Harbor, the two progressive factions took opposite sides on the issues of the rights of Japanese Americans.

In 1945, anti-Japanese organizers across the state, including Pierce, American Legion officials, and Portland politicians called for the permanent exclusion of Japanese Americans. The racist rhetoric of these organizers drew the ire of the Portland Council of Churches, civic leaders, and War Relocation Authority officials, 
who formed the Portland Citizens Committee to Aid Relocation, the main white group to help returners find housing and employment. Their arguments for tolerance depended heavily on the story of Japanese American military service during World War II.

Responding to the shape of debates within the white community, returning Japanese Americans community leaders, especially Toshi Kuge and George Azumano of the Portland Japanese American Citizen's League (JACL), used the rhetoric of military service to demonstrate their Americanness after World War II. The rhetoric of valorous military service provided the ideological center of both remerging Japanese American leadership organizations and connections between the Nikkei community and white civic leaders.

After the reestablishment of Japanese American community organizations in Portland, Issei leaders lead a successful fundraising campaign to support a legal challenge to overturn the Oregon Alien Land Law and fund the Portland JACL. Subsequently, between 1946 and 1948, the Portland JACL served as liaisons between the Japanese American community and the white Portlanders interested in overturning laws that challenged Issei social and economic rights. Despite their efforts, Japanese Americans in the early postwar period, along with other Portland minority groups, faced significant discrimination in housing options, employment, and even blood supply. Their experience demonstrates both the power and limitations of arguments for racial tolerance in the early postwar period. 


\section{Dedication}

For my father, the late Alan T. Hegwood, who fostered my love of history and taught me that community service can be a way of life. 
Acknowledgements

A great many people in my life put up with, supported me, and offered much needed guidance throughout this project. First of all, I would like to thank my wife Amy, who patiently listened to my rambling explanations, suffered extreme boredom during our vacations when I took the afternoon in the archives, and most importantly provided the love and support that helped me develop confidence as a writer and historian.

I would also like to thank my advisor, Kenneth J. Ruoff, for taking on a student studying issues outside of his field, providing valuable advice for developing my research, and making sure that I kept my eye on the next step in my career. I am grateful as well to Hillary Jenks for sharing her extensive knowledge of the broader context of Asian American history as well as insightful criticisms of early drafts of this work. Thanks also to Katrine Barber and David A. Johnson of the Portland State University History department for all their help with my thesis project, especially in filling in the many gaps in my argument.

This project would not have been possible at all, though, had the Portland chapter of the Japanese American Citizen's League (JACL) had not been willing to allow a complete stranger full access to their chapter's archives. My heartfelt thanks go to the JACL board and to Co-president Jim Kennedy especially. Their archives are currently being organized under the able care of archivist Cristine Paschild, who also deserves my thanks, at the Portland State University Library Special Collections Department. My thanks go also to Oregon Nikkei Legacy Center's Exhibit Director Nicole Nathan for all of her help with my research. 
Finally, thanks to Robert Findlay and Kat Cleland, who were my constant companions and co-conspirators during my studies here at Portland State University. 
Table of Contents
Abstract
Dedication $\quad$ iii
Acknowledgements
Chapter 1: Introduction 1
Chapter 2: $\quad$ Progressivism and Class Conflict in the 1930s 14
Chapter 3: "Despite Race, Color, or Creed" 49
Chapter 4: $\quad$ Experiments in Acceptance 86
Chapter 5: $\quad$ Successes, Failures, and Regular Minority Status 108
$\begin{array}{ll}\text { Chapter 6: } & \text { Conclusion } \\ & 138\end{array}$
$\begin{array}{lr}\text { References } & 146\end{array}$ 
Chapter 1: Introduction

Demographically, Portland has a distinct place in the historiography of the Japanese American experience. In 1940, just 4,071 Japanese Americans lived in Oregon (1,617 Issei and 2,454 Nisei), of which 1,680 lived in Portland. ${ }^{1}$ Conversely, California was home to nearly 94,000 Japanese Americans in $1942 .^{2}$ Subsequently, the majority of histories written about Japanese Americans before World War II, the wartime incarceration of the 120,000 Japanese Americans living on the West Coast, and the resettlement era between 1945 and 1952 focus on the experience of Californian individuals of Japanese descent. For instance, Dorothy Swaine Thomas' authoritative examination of the return of Japanese Americans to the West Coast contains no statistics on Oregon Nikkei. ${ }^{3}$

On those occasions when Oregon does comes up in scholarship on Japanese American resettlement, authors point to anti-Japanese racism, mainly in rural areas, to show that it was widespread up and down the West Coast. ${ }^{4}$ Population statistics seem to justify this academic focus. However, the small size of the Portland Japanese

\footnotetext{
${ }^{1}$ Barbara Yasui, “The Nikkei in Oregon, 1843-1940," Oregon Historical Quarterly 76 (September 1975), p. 253. Hito Okada, President Portland Japanese American Citizen's League, Statement Before House Defense Migration Committee, 26 February 1942, Hito Okada File, PDX JACL Collection.

${ }^{2}$ War Agency Liquidation Unit, People in Motion: The Postwar Adjustment of the Evacuated Japanese Americans, (Washington D.C.: U.S. Government Printing Office, 1947), p. 82.

${ }^{3}$ Dorothy Swaine Thomas, The Salvage: Japanese American Evacuation and Resettlement, (Berkeley: UC Berkeley Press, 1952). People in Motion gives a similar report, focusing on factors that effected Japanese Americans in postwar business and housing readjustment, but makes no substantive examination of conditions in Oregon.

${ }^{4}$ For instance, People In Motion, p. 69. Audrie Girdner and Anne Loftis, The Great Betrayal: The Evacuation of the Japanese Americans During World War II, (London: MacMillan, 1969), p. 360. Eiichiro Azuma, Between Two Empires: Race, History, and Transnationalism in Japanese America, (Oxford: Oxford UP, 2005), pp. 58, 74, 79-80, 127.
} 
American community is a major part of what makes it an ideal case study of how Japanese Americans in the postwar era carved out a social and economic space for themselves in an overwhelmingly white community.

The story of the return of Japanese American evacuees to Portland, Oregon, is more than just one of coping with economic hardship and racial discrimination. The return was also a time of negotiated social space and identity. While busy finding work and housing in Portland between 1945 and 1948, Japanese Americans also sought to secure the full rights and privileges of American citizenship for themselves in legal codes and in the public eye. An understanding of the changing attitudes of the white majority, especially progressives, is paramount to interpreting the strategies of acceptance employed by self-proclaimed Japanese American community leaders.

This study examines Japanese American resettlement in Portland, Oregon, in two respects. The first focuses on white progressives in pre-World War II Portland and the very public debates over the rights of Japanese Americans during the Pacific War. The second examines methods the Portland Japanese American Citizen's League (JACL) employed to establish Japanese American claims to the full rights of American citizenship, their relationship to the white community, and the environment of anti-Japanese discrimination in postwar Portland. Transnational, national, and local conflicts and identity construction intersect in the story of the return of Japanese Americans to Portland. ${ }^{5}$

\footnotetext{
${ }^{5}$ As in Gary Y. Okihiro's work, this thesis attempts to sketch out transnational, national, and local dimensions of identity by placing Asian American history in a more central place, rather than treating their experience as peripheral to larger movements. Okihiro uses an emphasis on Asian Americans to recenter American history as a whole. Here the focus is far less ambitious, attempting to refocus and
} 
Chapter One focuses on how the roots of progressivism in Oregon are partly transnational in origin. Progressivism in Oregon was both democratic and opposed to Asian immigration. To understand the linkage, one must problematize the term progressivism. In an attempt to historicize the story of progressivism in America, historians have erected a dichotomy between more "authentic" progressives who fought for economic and poltical rights despite race, religion, or creed and their populist counterparts who were often known for their nativist sentiment. A quandary for historians emerges from this dichotomy when attempting to make sense of figures like Oregon Governor Walter M. Pierce, who was a progressive proponent of democracy, but only for whites. ${ }^{6}$

A transnational focus helps make sense of this historical dilemma. In Drawing the Global Colour Line, Marylin Lake and Henry Reynolds argued that an international community of whiteness developed around the turn of the century that "defined their identity and rights in racial terms: the right of Anglo-Saxons to selfgovernment and the commitment of white workers to high wages and conditions, against those they saw as undermining their newfound status, whether they be aristocrats or "coolies.", In a way perhaps shocking to the contemporary perspective,

reinterpret the history of Portland, Oregon using a focus on Japanese Americans. See: Gary Y. Okihiro, Common Ground: Reimagining American History, (Princeton, NJ: Princeton UP, 2001), p. 17.

${ }^{6}$ Recently, Oregon historian Robert R. McCoy conceptualized Pierce's seemingly contradictory stances as evidence of the coexistence dual political impulses in the early twentieth century. On one hand, Pierce "maintained his belief in direct democracy, moral capitalism, and the defense of civil liberties throughout his career." On the other hand, he supported the nativist and racist attempts to racially purify Oregon. McCoy portrayed Pierce as a paradoxical embodiment of these reactionary and progressive impulse. See Robert R. McCoy, “The Paradox of Oregon's Progressive Politics: The Political Career of Walter Marcus Pierce,” Oregon Historical Quarterly 110.3 (Fall 2009), pp. 391-392.

${ }^{7}$ Marylin Lake and Henry Reynolds, Drawing the Global Colour Line: White Men's Countries and the International Challenge of Racial Equality, (Cambridge: Cambridge UP, 2008), p. 7. 
these whites were at once advocates of progressive democratic reform like women's rights and workers' rights, but sought to create a homogeneous, racially white society. In self-identifying white settler colonies in the majority of British Commonwealth countries and in the American West Coast states, Chinese and Japanese immigrants faced discrimination and wholesale exclusion. Racism and progressivism came from that same impulse to create a more perfect democratic society, but only for whites.

Oregon's exclusionary and progressive movements both fit this model, which looks like a tortured version of progressivism from the modern perspective. Oregon progressives before World War II saw the cause of democratic reform as a fight between the ordinary man and monied interests. For progressive leaders like Pierce and leaders of the Oregon Grange, seeking the full benefits of American citizenship for the white worker meant opposing the interests of Portland financiers and conservatives and their desire to introduce non-white workers. In the case of Oregon, those non-white workers were largely Asians. This transnational political movement will be referred to here as racially exclusive progressivism. ${ }^{8}$

In the 1930s, farm and labor groups in Oregon formed a broad progressive alliance known as the Oregon Commonwealth Federation (OCF) in support of New Deal programs. ${ }^{9}$ Although the OCF proclaimed an ideal of equality despite race,

\footnotetext{
${ }^{8}$ This term is quite similar to Alexander Saxton's "racially exclusive democracy" concept, which he used to explain that, "If there was an American orientation to newcomers, it was not towards giving equal opportunity to all, but towards inviting entry by white Europeans and excluding others." By the twentieth century, in Oregon, progressives interested in bettering the economic situation of working class, white Americans, embraced racial exclusion. Conversely, conservatives and businesses interests in Oregon opposed racial exclusion. Alexander Saxton, The Rise and Fall of the White Republic: Class Politics and Mass Culture in Nineteenth-Century America, (London: Verso, 1990), p. 10.

${ }^{9}$ Oregon Commonwealth Federation pamphlet, "And Now-the Truth About the Oregon

Commonwealth Federation," Pierce Collection, University of Oregon Archives, Collection 68, Box 20, Folder 1 .
} 
religion, or creed, they mainly focused on ensuring that the abundant electricity produced by the 1930s era construction of hydroelectric dams on the Columbia River benefited Oregon's working class. When their efforts failed in a series of ballot measures around 1940, the OCF collapsed. The collapse of this progressive coalition left Oregon's progressives dispirited and disorganized. ${ }^{10}$ Progressives like lawyer Gus J. Solomon, who became an advocate on behalf of returning Japanese Americans, were silent as the Army rounded up Japanese Americans and placed them in incarceration camps in 1942. Other former members of the OCF, like Pierce and Oregon Grange officials, actively pursued the exclusion of Japanese Americans following Pearl Harbor.

Chapter 2 examines the shift in power between pro- and anti-Japanese groups in Portland. Interpretations of Oregon progressivism have rendered previous locallevel examinations of the Japanese American return problematic, especially in their interpretation of anti-Japanese movements. Labeling Oregon's anti-Japanese movement before, during, and after the Pacific War as a reactionary rural movement represents an unconscious attempt to divorce racially exclusive progressivism from postwar civil rights progressivism.

However, Portland was as much a center of public anti-Japanese activity as anywhere else in Oregon before and during World War II, until the press turned against the movement in late 1944. Although Portland business interests argued against anti-Japanese measures consistently until World War II out of fear of losing

\footnotetext{
${ }^{10}$ Harry H. Stein, Gus J. Solomon: Liberal Politics, Jews, and the Federal Courts, (Portland, OR: Oregon Historical Society Press, 2006), 71.
} 
the lucrative shipping trade with Japan, ${ }^{11}$ they did little to aid Japanese Americans. Portland's business leaders made their attitudes toward Japanese Americans plain in the wake of Pearl Harbor. Free from the necessity of maintaining good relations with Japan, the Chamber of Commerce aligned Portland City Council revoked Japanese business licenses and called for the internment of Japanese Americans. ${ }^{12}$

Although confrontational public displays of anti-Japanese behavior in Portland subsided by mid-1945, anti-Japanese discrimination did not cease. During the Pacific War, an alliance of pro-Japanese groups sprung up in Portland in opposition to calls for permanent Japanese exclusion. Especially after the Hood River controversy in late 1944 and early 1945, Portland progressives and church groups sought to quell antiJapanese sentiment as a way to demonstrate Portland's fair-mindedness. Due to their opposition of perceived racist fascism and out of guilt for their failure to stand up for Nikkei civil rights in 1942, progressive Gus J. Solomon, former Governor Charles Sprague, and others engaged in a series of public battles with anti-Japanese organizers over the loyalty and legitimacy of Japanese American claims to the full rights of American citizenship. Groups like the Portland Council of Churches were chiefly interested in eliminating the spectacle of anti-Japanese discrimination. ${ }^{13}$ The importance of the narrative of Nisei military service to the pro-Japanese argument can hardly be overstated.

\footnotetext{
${ }^{11}$ Arthur H. Bone, Oregon Cattleman/Governor, Congressman: Memoirs and Times of Walter M. Pierce, (Portland, OR: Oregon Historical Society Press, 1981), p. 191.

${ }^{12}$ Eisenberg, p. 544.

${ }^{13}$ For an in depth study of anti-Japanese rhetoric in the media as spectacle see: Emily Roxworthy, The Spectacle of Japanese American Trauma: Racial Performivity and World War II, (Honolulu: University of Hawaii Press, 2008).
} 
In 1945, the Portland Citizen's Committee to Aid Relocation, an ad-hoc committee of Portland civic, religious, and progressive leaders formed in February 1942, made public anti-Japanese rallies in Portland impossible. They then spoke out against anti-Japanese organizers, like Pierce and the Japanese Exclusion League, in rural meetings, creating an illusion that opponents of the Japanese American return to Oregon were backwoods racists. Emerging postwar civil rights progressives sought to define themselves in opposition to this rural, reactionary other. Thus racially exclusive progressivism was reimagined with rural origins. In the majority of scholarship on Japanese Americans in Oregon, the rural towns of Hood River and Gresham emerge as centers of anti-Japanese activism. Alternately, Portland was portrayed as a place uniquely friendly to returning Japanese Americans because of the work of church groups and civic leaders to combat "race baiting.","

The debate over the return of Japanese Americans in Oregon formed along the lines of Gary Gerstle's conception of civic versus racial nationalism. Racially exclusive progressives of the anti-Japanese alignment harbored a conception of America as "held together by common blood and skin color and by an inherent fitness for self-government." Civic nationalists, that is, War Relocation Administration officials, civic leaders, progressives, and church leaders, instead espoused a "democratic universalism" based on concepts of equality and inalienable rights to

\footnotetext{
${ }^{14}$ For Two examples see Beatrice Stevens, Free and Equal: The Japanese Americans in Oregon, (Portland, OR, 1945), and Marvin Gavin Pursinger, Oregon's Japanese in World War II: A History of Compulsory Relocation, Dissertation, University of Southern California, 1961.
} 
liberty. ${ }^{15}$ The movement to intern Japanese Americans was a spasm of racial nationalism, as expedited by the Pearl Harbor Incident, or as Eiichiro Azuma described the movement, "an amalgamation of nationalism and racism which culminated in a complete polarization between things Japanese and things American in each warring state." 16 Alternately, the public reaction against anti-Japanese racism in 1945 was a surge of civic nationalism.

Chapter Three examines Japanese American attempts to establish their claims to the legal and social benefits of American citizenship in the postwar era. As Tetsuden Kashima observed, the decade after wartime incarceration was a time of crisis, not a period of smooth transition into a model minority status. ${ }^{17}$ In Portland, this crisis took the form of continuing discrimination by the Portland City Council and other Portland officials who maintained earlier perceptions of them as the Japanese “other" along wartime lines. ${ }^{18}$ Although Daiichi Takeoka, Ted Hachiya and other Japanese American community leaders waged successful campaigns against legal barriers to the economic livelihood of Japanese Americans in Oregon, Portland realtors continued to bar them from living in white neighborhoods. Japanese Americans also continued to face discrimination in hiring, and vandals continued to desecrate the Portland Japanese cemetery.

\footnotetext{
${ }^{15}$ Gary Gerstle, American Crucible: Race and Nation in the Twentieth Century, (Princeton: Princeton UP, 2001), p. 4.

${ }^{16}$ Eiichiro Azuma, Between Two Empires: Race, History, and Transnationalism in Japanese America, (Oxford: Oxford UP, 2005), p. 209.

${ }^{17}$ Tetsuden Kashima, "Japanese American Internees Return, 1945 to 1955: Readjustment and Social Amnesia," Phylon, Vol 41, No. 2, (2 ${ }^{\text {nd }}$ Qtr., 1980), p. 108.

${ }^{18}$ As John W. Dower has explained, the Pacific War was quite nearly a race war between Japan and the United States, at least in terms of the two countries' propaganda. See, John W. Dower, War Without Mercy: Race and Power in the Pacific War, (New York: Pantheon, 1986).
} 
Japanese Americans returning to Portland employed several strategies to gain acceptance. According to the papers of the Portland Japanese American Citizen's League (JACL), the chief strategy employed by Portland Issei and Nisei was a connection to the $442^{\text {nd }}$ Army Regimental Combat Team's narrative of valorous service during World War II. In an environment of continuing discrimination, the Portland JACL and Japanese Ancestral Society publicly connected to the $442^{\text {nd, }}$ s story to legitimize claims of loyalty and to support arguments that they deserved the full benefits of American citizenship, in campaigns such as the 1947 court challenge to the 1945 updating of the Oregon Alien Land Law.

Portland JACL leaders Toshi Kuge and George Azumano used this tactic, referred to here as the Nisei Patriotism argument, to avoid a more direct confrontation with the American public over their civil rights while attempting to distance themselves from their Japanese identity. The Nisei Patriotism argument was an attempt to engage civic nationalists without inflaming racial nationalists. On a symbolic level, JACL leaders used this argument to portray Nisei combat troops in the guise of a patriotic, white American soldier. During World War II, anti-Japanese arguments in the press often idealized soldiers and military leaders such as Douglas MacArthur as the chief line of defense against a monstrous racially-monolithic Japanese other. ${ }^{19}$ Both civic leaders, such as E. B. Macnaughton, and many U. S. soldiers themselves resented portrayals of American military forces as "missionaries

\footnotetext{
${ }^{19}$ Roxworthy, p. 109.
} 
for Jap hating." ${ }^{20}$ Both JACL leaders and War Relocation Authority officials, the administrative authorities in charge of Japanese internment camps, reclaimed the image of the American soldier as fighting for democracy despite race, religion, or creed through descriptions of Japanese Americans fighting the forces of fascism. ${ }^{21}$

Chapter 4 describes the successes and limitations of the Portland JACL as a community group and political movement between 1947 and 1948. Postwar national JACL policy directives, as implemented in Portland, sought to rely on white civil rights progressives as public advocates for Japanese American civil rights. The JACL attempted to regularize this process through local-level and national AntiDiscrimination Committees. These committees created Caucasian advisory boards, essentially groups of white civic leaders that supported them during the early return period, that could be counted on to write to their congressman on behalf of laws favoring Japanese Americans. The JACL literally sought to make whites the authors of full citizenship for Japanese Americans. ${ }^{22}$ This JACL tactic allowed civic nationalists to argue for the civil rights of Japanese Americans without exorcising concepts of cultural and racial difference, thus laying the ground work for the model minority conception of Japanese American identity. ${ }^{23}$

\footnotetext{
${ }^{20}$ Eleanor N. Forden. “Stands by Local Japanese," Oregon Journal, 12 March 1945 and "Service Men Tolerant," Oregonian, undated March 1945, Mizuta Scrapbook, George Mizuta, Microfilm 154, Oregon Historical Society Research Library.

${ }^{21}$ Examples of this argument are abundant in newspapers written by the Nisei in incarceration camps such as the Minidoka Irrigator and Heart Mountain Sentinel. For an example dealing with Oregon, see: Kimi Tambara, “An Appeal to Courage,” Minidoka Irrigator, 24 March 1945, p. 4. The WRA also produced numerous public information pamphlets like "Nisei in the War Against Japan" and others. ${ }^{22}$ There is an interesting correlation here between Japan's postwar constitution, written by members of U.S. Occupation staffers, and postwar JACL dependence on white allies in legislative campaigns that may be fruitful for further explanation.

${ }^{23}$ The Model Minority conception of Asian American history sought to explain the success of Asian Americans in the American, capitalist economic system through cultural differences, such as a tradition
} 
Throughout the internment period, the national JACL had sought to enforce submission to military authority, at times denouncing Japanese Americans bold enough to challenge curfew orders, and at other times failing to support court cases testing anti-Japanese statutes. ${ }^{24}$ Because public perceptions of loyalty were the currency of campaigns for legal redress, the national JACL wanted firm control of Japanese American requests for recognition of their constitutional rights. After the war, JACL leaders in Portland were given a narrow path on which to challenge racial discrimination, limiting their ability to make common cause with other minorities.

The JACL emphasis on the Nisei patriotism argument dovetailed with the needs of the white community, but alienated large portions of the Japanese American community, especially, when they returned home to find that embracing the American national identity did not prevent continuing discrimination in employment and housing. ${ }^{25}$ Furthermore, many Japanese Americans, such as the Voice of the Nisei movement, active during internment and the National Council for Japanese American Redress, active in the 1970 s, continued to view the JACL as collaborators in the Nikkei incarceration. ${ }^{26}$ This alienation survives in numerous Portland JACL accounts of widespread disinterest in chapter activities. Only a fraction of the Portland Nisei

of Confucianism. This conception allowed scholars to continue seeing Asians as the "other" while maintaining a belief that American society had reached a stage of racial equality. Essentially cultural difference replaced taboo concepts of racial difference. Chih-Chieh Chou, "Critique on the Notion of Model Minority: An Alternative Racism to Asian American?" Asian Ethnicity, Vol. 9, No. 3, October 2008, p. 219.

${ }^{24}$ Stephanie Bangarth, Voices Raised in Protest: Defending North American Citizens of Japanese Ancestry, 1942-1949, (Vancouver, UBC Press, 2008), 156-174.

${ }^{25}$ Caroline Chung Simpson, An Absent Presence: Japanese Americans in Postwar American Culture, 1945-1960, (Durham, NC: Duke UP, 2001), 73.

${ }^{26}$ Brian Masaru Hayashi, Democratizing the Enemy: The Japanese American Internment,(Princeton, NJ: Princeton UP, 2004), p. 186. Alice Yang Murray, Historical Memories of Japanese American Internment and the Struggle for Redress, (Stanford: Stanford UP, 2008), p. 2. 
community joined the JACL in the early post-internment era. Of that fraction, few were willing to participate in leadership roles. Therefore, only a handful of Portland Japanese Americans shouldered the burden of implementing the JACL program in Portland.

Activities and causes that garnered the most support and participation on the part of the Portland Japanese American community were those that dealt with local economic and social problems. In 1946, Portland Issei leaders sought legal acceptance through support of the Oregon Alien Land Law Test Case Committee. ${ }^{27}$ At the height of the debate over Japanese American return in 1945, the legislature had passed a measure strengthening the 1923 Alien Land Law along the lines of the California model. ${ }^{28}$ Unlike Japanese Americans in California, landowners in Oregon had not previously faced an effort by the state to seize Issei farms with deeds under their children's names. ${ }^{29}$ Despite the lack of a direct threat, the Portland-based Community Affairs Council, a joint Issei-Nisei community group, formed the test case committee to avoid future loss of property.

The Alien Land Law Test Case Committee enjoyed broad-based financial support, especially among Issei, because their program would aid all Japanese Americans. Such economic efforts more fully represented the desires of the Japanese American community than did the JACL, who rankled many because of perceptions that the organization collaborated in internment and that it was only interested in

\footnotetext{
${ }^{27}$ Eiichiro Azuma, “A History of Oregon's Issei, 1880-1952,” Oregon Historical Quarterly, Winter 1993-1994, 356.

${ }^{28}$ Amy K. Buck, "Alien Land Laws: The Curtailing of Japanese Agricultural Pursuits in Oregon," Masters Thesis, Portland State University, 1999, p. 73.

${ }^{29}$ Charlotte Brooks, Alien Neighbors, Foreign Friends: Asian Americans, housing, and the Transformation of Urban California, (Chicago: University of Chicago Press, 2004), p. 181.
} 
aiding the Issei in a bid to position themselves as leaders of the Japanese American community.

Despite the distinct challenges facing the Portland JACL, it served as the main organizational contact between the Japanese American community and the white community. Because of this contact, the JACL was able to garner larger Japanese American community participation in economic issues such as during efforts to document personal losses as part of 1948 Evacuation claims legislation and to aid victims of the 1948 Vanport flood. Portland JACL leaders were the chief agents working with the emerging civic nationalist consensus in Portland in the postwar era. 
Chapter 2: Progressivism and Class Conflict in the 1930s

Oregon as a whole and Portland in particular has existed since its founding in the midst of local, national, and international discussions about progressivism. In the nineteenth century, citizens of British Commonwealth countries, along with those in California and other West Coast American states, sought to create more democratic, but also homogeneously white, societies because they believed whiteness was a prerequisite for democratic civilization.

Transnational conversations on Asian immigration by British writers like Charles Pearson, 'trust-busting” U.S. President Theodore Roosevelt, and Oregon Governor Walter M. Pierce tied reforms to aid the white working and middle classes to arguments for nonwhite exclusion, forming an ideological movement, termed here as racially exclusive progressivism, by the turn of the century. This impulse found its form partially through exclusion laws, such as California's 1913 Alien Land Law and Oregon's 1923 Alien Land Law, which were designed to shore up white economic status in the face of perceived racial threats. The Democratic Parties of California and Oregon embraced the same impulse, eventually fueling calls for Japanese internment in 1942. Because of Oregon's history of racially exclusive progressivism preceding World War II, anti-Asian sentiment was often a major force in Portland and wider Oregon politics. Understanding Pierce's role in various anti-Japanese movements, during his years as Oregon State Senator in 1902-1906, as Oregon Governor from 
1923 to 1927, and U. S. Representative from 1932 to 1942, helps explain how pre-

1930 Oregon progressivism fits into this racially exclusive progressive model.

The majority of scholarship dealing with anti-Japanese movements in Oregon has ignored progressivism's role in Japanese exclusion. Oregon historians instead tend to focus on rural organizations like the Grange, the Hood River American Legion, or the Gresham-based Japanese Exclusion League. Meanwhile, calls for exclusion by Portland's progressive leaders enter at the margins, if at all. In both popular histories, like the story of the Hood River Yasui Family told in Stubborn Twig and in more academic histories such as Linda Tamura's Hood River Issei, anti-Japanese activism in Oregon is portrayed with solely rural origins. ${ }^{30}$

Likewise, scholarship on Oregon progressivism deals with racially exclusive progressivism through bifurcation. Pierce provides a useful example in this regard as well. Discussions of Pierce often juxtapose his advocacy of the Oregon System of referendum and initiative near the turn of the century and his full-fledged support for the New Deal against his ideological commitment to eugenics and Japanese exclusion. The contradiction is a product of historiography. In the 1970s, historians tried to make sense of the progressives by dividing them into to groups, "urban liberals" and "old stock, patrician farmers," leading to the conclusion that one group represented

\footnotetext{
${ }^{30}$ Lauren Kessler, Stubborn Twig: Three Generations in the Life of a Japanese American Family, (Corvallis, OR: Oregon State University Press, 2005). Linda Tamura, The Hood River Issei: An Oral History of Japanese Settlers in Oregon's Hood River Valley, (Urbana, IL: University of Illinois Press, 1993). See also: Marvin G. Pursinger, "Oregon's Japanese in World War II: A History of Compulsory Education," Dissertation, University of Southern California, 1979. Amy K. Buck, "Alien Land Laws," Master's Thesis, Portland State University, 1999. Anne Francis Galiskey, "Repressive Populsim and the Internment of Japanese Americans of the Pacific Northwest," Master's Thesis, Portland State University, 2003.
} 
"genuine progressivism" and the other a "false progressivism." ${ }^{31}$ Following this trend, a recent study of Pierce describes his ideology as deeply contradictory and goes so far as to divide his history into two conflicting legacies: one section focuses on Pierce's democratic reforms, the other section focus purely on his discrimination. ${ }^{32}$ Pierce's ideology was not schizophrenic; it merely has previously unrecognized transnational ideological origins.

The Portland City Council was also distinctive in its belligerence towards the Nikkei after the Pearl Harbor incident, being the only city on the West Coast to revoke Issei municipal business licenses. Furthermore, Portland was notable for the lack of white public outcry against the policy of internment at a series of Congressional hearings held in February of 1942. Known as the Tolan Committee hearings, these hearings intended to poll public sentiment about President Franklin D. Roosevelt's Executive Order 9066, the directive responsible for the internment of West Coast Nikkei during World War II. ${ }^{33}$ Historical understandings of Portland as a place of civil rights progressivism before Japanese American incarceration thus cannot be borne out by the historical record. That view both disinherits the legacy of racially exclusive progressivism in Portland, and paints rural Oregon as the source of reactionary racial politics.

\footnotetext{
${ }^{31}$ Daniel T. Rodgers, "In Search of Progressivism," Reviews in American History 10, (1982), pp 151, 122.

${ }^{32}$ Robert M. McCoy, “The Paradox of Oregon's Progressive Politics: The Political Career of Walter Marcus Pierce," Oregon Historical Quarterly, Vol. 110, No. 3 (2009), pp. 390-419.

${ }^{33}$ Eisenberg maintains this lack of dissent stemmed from both Portland's lack of a major public university and the lack of contact between the Nikkei and white communities. Ellen Eisenberg, "'As Truly American as Your Son': Voicing Opposition to Internment in Three West Coast Cities," Oregon Historical Quarterly, Winter 2003, 564.
} 
Civil rights progressives in 1930s Oregon, such as the lawyer and later federal judge Gus J. Solomon and labor activist Monroe Sweetland, failed to speak out against Japanese incarceration because of their close ties to Pierce and other racially exclusive progressives. Both groups worked together during the 1930s through the Oregon Commonwealth Federation (OCF), which brought together labor, farm, and civil rights progressives to support New Deal policies, especially the construction of hydroelectric dams on the Columbia River. In the 1930s, public power absorbed the majority of the combined energy of Oregon progressives.

The subsequent collapse of the OCF in 1940, due to the failure of a series of public power ballot initiatives, imploded the meager networks of civil rights progressive advocacy. ${ }^{34}$ This collapse left the Nikkei without white allies in the face of hostility from the Portland City Council, anti-Japanese progressives advocating for exclusion, and business leaders who saw internment as a financial opportunity. This study seeks to include transnational, national, and local-level focuses to understand the belligerence of the 1942 Portland anti-Japanese political alignment while exploring the silence of white advocates for the constitutional rights for Japanese Americans.

\section{Transnational Origins}

In 1850 s Victoria, Australia, there was a gold rush in which "hundreds of thousands of people arrived from all over the world." ${ }^{, 35}$ By 1854, 10,000 of these immigrants were Chinese farmers and traders from Canton seeking their fortunes abroad. According to historians Marilyn Lake and Henry Reynolds, "European miners

\footnotetext{
${ }^{34}$ Harry H. Stein, Gus J. Solomon: Liberal Politics, Jews, and the Federal Courts, (Portland: OHS Press, 2006), p. 71.

${ }^{35}$ Marylin Lake and Henry Reynolds, Drawing the Global Colour Line: White Men's Countries and the International Challenge of Racial Equality (Cambridge: Cambridge UP 2008), 17.
} 
criticized the Chinese because of their alien customs, clannishness, lack of women, labour competition, and fast increasing numbers. ${ }^{36}$ In response to the idea of being overrun by a possible deluge of Chinese immigrants, the people of Victoria called upon parliament to pass the Immigration Restriction Act of 1855. This act defined the Chinese in racial terms, placed a tax on incoming Chinese, and limited their immigration to one Chinese per every ten tons of cargo shipped to the colony. Labor unions and other colonists argued for Chinese exclusion based on a belief that "the ideal colonist was European, civilized, and a family man." ${ }^{37}$

The intent for this and subsequent immigration restriction was homegrown, but the legal model of exclusion used by the Victorian parliament originated in California. In 1850 , responding to fears that individuals unable to obtain citizenship were also reaping benefits of the post-1848 gold rush, the new California legislature passed a head tax of twenty dollars on all "foreign" miners, including French and Australian miners. The law was intended to remove Mexican and Chinese miners from claims in the state. In 1852, the Foreign Miners Law was revamped charging only $\$ 3$, but required all Chinese men to pay the tax before they could mine their claim. Enforced by an army of independent tax collectors, the 1850 and 1852 Foreign Miners Laws led to the expulsion of tens of thousands of Mexicans and Chinese. ${ }^{38}$ Head tax laws were only the first of many laws Australia based on the Californian example.

\footnotetext{
${ }^{36}$ Lake and Reynolds, 18-19.

${ }^{37}$ Lake and Reynolds, 20.

${ }^{38}$ Jean Pfaelzer, Encyclopedia of U. S. Labor and Working-Class History, Vol. 1, Eric Arnesen Ed., (New York: Routledge, 2007), pp. 468-469. The Foreign Miner Tax in California was especially insidious in its practice. The 1852 tax depended on independent tax collectors empowered to sell the possessions of Chinese miners. Half of the tax money went to county treasuries, half to state treasuries, and a fee went to the tax collector. This created a financial incentive for the state, counties, and
} 
Ideological support for exclusion measures in both states was similar as well.

In California and Victoria, some advocates for the working class believed that the "white worker was the bearer of civilization." ${ }^{39}$ White laborers in the post-bellum period moving to California defined themselves in opposition to the nearly fifty thousand Chinese laborers who represented one quarter of the labor force in the 1870 s. White laborers occupied nearly all jobs of skill and prestige and sought further benefits from their white employers like the eight-hour day and safer working conditions. When unions struck to obtain these benefits, labor contractors from the Six Companies of San Francisco often sent in Chinese laborers to replace them, reinforcing the belief among white laborers that "their Asiatic fellow workers...were too docile, too slave-like, to be able to ever to stand on their own feet in a free society. ${ }^{, 40}$ Chinese laborers were, in their view, unworthy as possible citizens and a threat to their fight for better wages and conditions. This is just one example of the intersection between progressivism and fears of a racial other.

In the 1880s, Victorian liberal legislator Charles Pearson framed these fears around a number. Arguing in support of an exclusion bill, Pearson stressed that the Chinese presented a profound threat to white civilization because the "natural increase" of their 400 million citizens would swamp the small populations of the white settler colonies surrounding the Pacific. ${ }^{41}$ Increasingly, the white working class of both states

individuals to fleece Chinese miners of what little profits their mining ventures brought them. Pfaelzer notes that Chinese miners provided between one fourth to one half of State tax revenue in the $1850 \mathrm{~s}$, roughly $\$ 58$ million.

${ }^{39}$ Lake and Reynolds, 32.

${ }^{40}$ Alexander Saxton, The Indispensable Enemy: Labor and the Anti-Chinese Movement in California,(Berkeley: University of California Press, 1995), pp. 7-10.

${ }^{41}$ Lake and Reynolds, 36. 
claimed that the capacity for self-government was the preserve of the Anglo-Saxon race. This racially exclusive progressivism was highly transportable among territories and states with British heritage, including Oregon.

Unlike the belief of some Oregon legal scholars, racism in Oregon was not "particular to its time and place." ${ }^{42}$ Rather, it was heavily influenced by a transnational, racially exclusive progressivism. Debates around the first Oregon constitution shows that exclusion of nonwhite groups had broad-based support. In 1857, the Oregon territorial legislature formed a constitutional convention. Key figures on the commission such as Chief Justice George Henry William "urged his colleagues to 'consecrate Oregon to the use of the white man, and exclude the Negro, Chinaman, and every race of that character." ${ }^{, 43}$ William was overruled on the Chinese issue, likely because key figures were interested in them as a source of cheap labor, but other measures of exclusion made their way on to the ballot in November of 1857. Oregon voters chose not only to ban slavery $(7,727$ to 2,645$)$ but also to bar free blacks and "mulattoes" from entering Oregon $(8,640$ to 1,081$) .{ }^{44}$ In 1860, the Oregon legislature followed a more explicit California-Australia model by increasing the tax against Chinese miners in Oregon. ${ }^{45}$

Opposition to slavery in Oregon stemmed from a desire to make Oregon an ideal place for white settlers. Banning slavery, as proposed by the Free Soil party in Oregon territory, was much more about keeping African Americans out of the territory

\footnotetext{
${ }^{42}$ Cheryl A. Brooks, "Politics of Forgetting: How Oregon Forgot to Ratify the Fourteenth Amendment," Journal of Oregon Humanities Fall/Winter 2006, 46.

${ }^{43}$ Brooks, 47.

${ }^{44}$ Brooks, 47.

${ }^{45}$ Brooks, 48 .
} 
than it was about the moral opposition to slavery. Free Soilers claimed that, "Slavery degraded white labor. It reduced white farmers, mechanics, artisans, and workingmen - indeed, everyone except the slave owner - to the debased status of the slave."46 The anti-slavery consensus was highly successful in keeping African Americans out of Oregon until World War II demands for labor sparked the first large influx of black migrants. ${ }^{47}$

Chinese were the only "visible minority" in Oregon until the 1880s, at roughly ten thousand members. Portland had a particularly high percentage, as high as twenty to twenty five percent in the mid-1880s, when white workers in Portland took to the street to demand the eviction of the Chinese from Portland. ${ }^{48}$ Like Australian miners and California laborers, white workers in Oregon "considered themselves robbed" of their livelihood by the Chinese. ${ }^{49}$ The complaints of Oregonians echoed a chorus of calls around the Pacific for the exclusion of the Asians in the interest of the preservation of the white race.

\footnotetext{
${ }^{46}$ David A. Johnson, Founding the Far West: California, Oregon, and Nevada, 1840-1890, (Berkeley: University of California Press, 1992), p. 64.

${ }^{47}$ The African American population in Portland, for instance, was fewer than 2,000 in 1940, but grew to over 23,000 by 1945 because of demand for labor in the Kaiser Shipyards. Rudy Pearson, "A Menace to the Neighborhood: Housing and African Americans in Portland, 1941-1945," Oregon Historical Quarterly, Vol. 102, No. 2, (Summer 2001), pp. 161, 163. 48 Johnson, p. 277.

${ }^{49}$ Lake and Reynolds, 34. Unlike the California experience, white workers in Oregon were largely nonviolent in their protests against Asian laborers. One of the few examples was the forced removal of twenty-seven Issei, four Filipinos, and one Korean laborer from Toledo, Oregon in 1925. In an attempt to improve the efficiency of more labor-intensive portions of their mill there, the Pacific Spruce Corporation hired the immigrant laborers. The Japanese laborers provoked a fierce backlash among Toledo residents who feared that the Japanese would "reap the benefits" of the efforts of early settlers in the Toledo area. Shortly after, a mob of fifty townsmen, both Scandanavian immigrants and native Oregonians, rounded up the Asian workers and drove them out of town enforced by threat of violence. See, Ted W. Cox, The Toledo Incident of 1925: Three Days That Made History in Toledo, Oregon, (Old World Publications: Corvallis, Oregon, 2005).
} 


\section{Racially Exclusive Progressivism at the National Level}

Around the turn of the century President Theodore Roosevelt's political ideas and practices illustrated this larger definition of progressivism. Roosevelt stood for a variety of progressive causes, ranging from support for diminishing concentrations of wealth to supporting the creation of national parks, but he also supported the transpacific conversation about the protection of white men's countries. These theories led white race proponents to think of Asians in international or transnational racial categories. In this framework, Anglo-Saxons and other transatlantic whites represented races fit for democracy.

Roosevelt became enamored of the idea of Anglo-Saxon civilization theories in his college years, leading him to maintain beliefs in the progress and superiority of white civilization. In 1894, he read a book that gave him a great cause for concern about the future of that civilization. ${ }^{50}$ Australian Charles Pearson's book National Life and Character confronted Roosevelt with a number of realities about racial demographics. Pearson argued that "black and yellow" races would eclipse white civilization because whites had both a much smaller population and a lower birth rate. ${ }^{51}$ Part of this ideology was based on a theory that white men were only suited to inhabit temperate regions. This led Roosevelt to applaud Australia and North American "commonwealths [for] their democratic insistence on race purity," which

\footnotetext{
${ }^{50}$ Lake and Reynolds, 95.

${ }^{51}$ Lake and Reynolds, 74.
} 
secured for the white race vast sections of the temperate zones surrounding the Pacific. $^{52}$

The anxiety that Pearson's book engendered was also a factor in Roosevelt's turn towards jingoism in the 1890s. His growing penchant for militarism was particularly represented in his response both to Japan's victory in the 1905 RussoJapanese war and his response to the Pacific Coast race riots of 1907. According to historian Erika Lee, white men's countries around the Pacific Rim responded to Japanese military prowess by embracing a cooperative and coordinated policy of shoring up the "White Pacific." 53 In San Francisco in 1907, as an offshoot of previous anti-Chinese campaigning, anti-Japanese groups took to the streets after being emboldened by a school board order to segregate Japanese students. ${ }^{54}$ At one point a mob turned violent, damaging a number of Japanese businesses. Similar riots occurred that year in Bellingham, Washington and Vancouver, Canada. ${ }^{55}$

These events only served to heighten concerns in the United States, Canada, and Australia about the "Asiatic issue." popular sentiment of the time. It warned, "The brown stream of Japanese would become a raging torrent." ${ }^{, 57}$ In order to shore up perceptions of a "White Pacific," in the wake of Japan's victory and popular protest against immigration, Roosevelt called for a "unity of action." He wanted all white men's countries of the pacific slope to halt

\footnotetext{
${ }_{53}^{52}$ Lake and Reynolds, 100, 102.

${ }^{53}$ Erika Lee, "The 'Yellow Peril' and Asian Exclusion in the Americas," The Pacific Historical Review Vol. 76, Issue 4, p. 550.

${ }^{54}$ Lee, p. 551. Lake and Reynolds, p. 170.

${ }_{56}^{55}$ Lee, p. 552.

${ }^{56}$ Lee, p. 553.

${ }^{57}$ Lake and Reynolds, p. 172.
} 
immigration from Asian countries to "the countries where the English-speaking peoples now form and will form the population of the future." ${ }^{58}$ In 1907, Roosevelt ordered a U.S. naval procession dubbed the "great white fleet" to tour the Pacific in support of the effort.

Another result of San Francisco's anti-Japanese agitation was a renewed embrace of Asian exclusion by progressive politicians like William Jennings Bryan and California Senator James D. Phelan. In an attempt to win the votes of Californians, the Democratic Party added an anti-Japanese plank to its party platform. Phelan in particular was known for his embrace of transnational yellow peril rhetoric. ${ }^{59}$ During Bryan's 1908 campaign for president, Phelan often tried to persuade voters that they should vote for Bryan because "only the Great Commoner [Bryan] could prevent the Pacific slope from being overrun by hordes of Japanese.",60

The California legislature crafted a number of anti-Japanese bills in 1909. Among the measures introduced was a school segregation bill targeting Japanese students and a bill barring Japanese nationals from land ownership designed to halt the movement of Japanese from San Francisco to inland farming communities. Because the school bill would directly contravene the "Gentlemen's Agreement" with Japan, Roosevelt urged the Republican California governor to step in and veto all antiJapanese bills.

\footnotetext{
${ }^{58}$ Lee, p. 554

${ }^{59}$ Phelan had strong ties to the labor movement in San Francisco including to the Building Trades Council's Japanese and Korean Exclusion League. For instance, in 1900 during his term as mayor he was a key speaker at the first convention among labor leaders to exclude Japanese immigrant workers from the Pacific Coast. Alexander Saxton, The Indispensable Enemy: Labor and the Anti-Chinese Movement in California,(Berkeley: University of California Press, 1995), p. 248.

${ }^{60}$ Daniels, 47.
} 
Californian plans to pass the Alien Land law were much more successful under the Woodrow Wilson administration in 1913. In an exchange with Senator Phelan during his presidential campaign provides an indication of Wilson's unwillingness to defend Japanese rights:

In the matter of Chinese and Japanese coolie immigration, I stand for the national policy of exclusion. We cannot make a homogeneous population out of a people who do not blend with the Caucasian race. Their lower standard of living as laborers will crowd out the white agriculturist, and is in other fields, a most serious industrial menace. The success of our free democratic institutions demands of our people education, intelligence, and patriotism and the state should protect them against unjust and impossible competition. Remunerative labor is the basis of contentment. Democracy rests on the equality of the citizen. Oriental coolieism will give us another race problem to solve and surely we have had our lesson. ${ }^{61}$

Despite the diplomatic problems it would cause, Wilson would not stand in the way of California's Alien Land Law of 1913. He decided instead to go on the record embracing the full gamut of anti-Asian rhetoric.

\section{Walter M. Pierce: Champion of the Common (White) Man}

Walter M. Pierce's political stance also fit into the model of racially exclusive progressivism, which illuminates the Oregon story of anti-Japanese agitation. Pierce was a self-identified liberal democrat who got his start in politics as the school superintendent of rural Umatilla County, Oregon in 1886 . He then rose through the state legislature to governor in 1922. From 1896 to 1902, Pierce was, at his core, a racially exclusive progressive reformer. In 1880 and 1886 Pierce supported Sylvester Pannier's campaigns for governor because of his support for anti-corruption measures and the exclusion of Chinese immigrants.

\footnotetext{
${ }^{61}$ Daniels, 55.
} 
From 1896 to 1902, Pierce also supported the measures known now as the Oregon System, spearheaded by William S. Uren, designed to undermine the influence of business in the Oregon state house. ${ }^{62}$ Inherent to this opposition movement was a reaction to the power of large financial interests to buy off legislators and move public resources into the hands of speculators. Pierce was concerned that such corruption disenfranchised those of little means such as farmers. Pierce by this time also supported Asian exclusion shown in his support for Sylvester Pennoyer's campaigns for Oregon governor in 1886 and 1880, which emphasized both reform and opposition to the Chinese. ${ }^{63}$

After Pierce was elected governor in 1922, he immediately went to work trying to alleviate the woes of white Oregon farmers, seeking to underline his image as the people's champion. Pierce sought a progressive taxation scheme that shifted property tax burdens from farmers to urban landholders. He also sought to eliminate unAmerican (a popular euphemism for nonwhites at the time) influences on Oregon. A key component of this push was a set of "Americanism bills" including a Californiastyle Alien Land Law. ${ }^{64}$ Bills seeking to bar alien land ownership had been introduced into the Oregon legislature in both 1911 and 1917 at the behest of the American

\footnotetext{
${ }^{62}$ Bone, 37.

${ }^{63} \mathrm{McCoy}, 407$.

${ }^{64}$ The California Alien Land Law was the product of a labor-progressive alliance in the California legislature following the 1910 election. Saxton argues that the main product of this alliance was an increased belligerence towards the Japanese, expressed through Alien Land Law. The law was easily circumvented but laid an important precedent in legal language targeting Japanese Americans. See Saxton, pp. 256-257.
} 
Legion and the Grange, but had been tabled by request of the State Department due to international negotiations. $^{65}$

The arrival of the Oregon Ku Klux Klan onto the political scene in the early 1920s strengthened the cause of Japanese exclusion. The Klan in Oregon was a product of the larger racially exclusive progressive movement, which was Anti-Asian, opposed to financial corruption in state government, and was not confined to the countryside. ${ }^{66}$ Japanese immigrants in Oregon were essentially caught up in the conflict between middle class Oregonians and Portland business interests.

While Klan proponents advocated for "oriental exclusion," the Oregon Chamber of Commerce opposed the alien land bill because they believed that business would move to Vancouver, British Columbia if the Japanese were no longer welcome in Oregon. W. D. B. Dobson of the Portland Chamber of Commerce "acknowledged that it was important to keep Oregon white and American," but it was necessary for economic recovery from the Post-World War I depression not to block the growth of business. ${ }^{67}$ The Chamber of Commerce's real concern here was the $\$ 69$ million per

\footnotetext{
${ }^{65}$ Bone, 190. Oregonian, 5 March 1922, 16.

${ }^{66}$ Heavy Klan support for Pierce should also be interpreted as heavy support in Portland for Pierce. In 1922, Oregon Grand Dragon Frank Gifford claimed to have 14,000 members, 9,000 of which hailed from Portland. See "Gifford Head of K. K. K.," Oregon Voter, 25 March 1922, p. 6. David A. Horowitz also writes that the Oregon Klan of the 1920s is often described as reactionary and dismissed as rural nativists, but it is more accurate to describe the Klan as a middle-class purity crusade. They supported "100 percent Americans" and opposed so-called hyphenated Americans. Klan members largely identified as producers and 90 percent of them were truly of the middle class or lower placing them well within the perameters of racially exclusive progressivism. See David A. Horowitz, Inside the Klavern: The Secret History of a Klu Klux Klan of the 1920s, (Carbondale, IL: Southern Illinois UP, 1999), pp. 2, 13.

${ }^{67}$ Buck, 42 .
} 
year in trade with Japan. ${ }^{68}$ Farm groups and the American Legion favored the bill, seeing the Japanese land ownership as a further threat.

Similar to the earlier Australian parliament's borrowing from the California model, the Oregon Alien Land Law of 1923 did not explicitly name Japanese immigrants in the bill, but they were certainly the implied targets. In this sense, drafters of the bill followed the model of California's 1913 Alien Land Law. Roger Daniels explains that the phrase "aliens ineligible for citizenship" is the key wording used by California lawmakers to target Japanese immigrants. Because U.S. naturalization law only allowed free whites to be citizens, and African American citizenship had already been provided by the Fourteenth amendment, the only significant racial category left was Asians. ${ }^{69}$ By 1922, the U. S. Supreme Court had spoken on the issue of Japanese citizenship in Ozawa v. US, claiming that it did not matter that Takao Ozawa had assimilated into American culture and had white skin; he was not Caucasian and thus ineligible for citizenship. ${ }^{70}$ Although citizenship for Issei would invalidate the Alien Land Laws, that avenue lay far out of reach.

\section{Oregon Progressivism in the 1930s: The Oregon Commonwealth Federation}

During the 1930s, progressives in Oregon continued to battle against business interests in Oregon, shifting their focus away from Asian exclusion. Instead,

\footnotetext{
${ }^{68}$ Bone, p. 95.

${ }^{69}$ Daniels, 50.

${ }^{70}$ Ozawa's attorneys argued that the Japanese are a free people, "most are white, speaking an Aryan tongue and having Caucasian root stocks, a superior class, [sic] they are assimilable." Ozawa's case thus used the framework of scientific racism to include people of Japanese descent in the category of acceptable whiteness, that is, both white and Caucasian. The Justices disagreed in a decision based on the common-sense notion that "white persons" referred to in the U. S. Immigration act of 1875 included only those deemed by the writers to be white. This group included immigrants from Europe, but excluded minorities that are visibly nonwhite. See: Matthew Jacobsen, Whiteness of a Different Color: European Immigrants and the Alchemy of Race, (Cambridge: Harvard UP, 1998), p. 235.
} 
progressives became consumed by attempts to ensure that the material benefits of the abundant electricity produced by dams on the Columbia River went to average ratepayers, rather than corporations. Oregon conservatives, like Democratic Governor Charles H. Martin and the Portland Chamber of Commerce, instead believed that projects like the Bonneville dam were designed to build up industries such as aluminum production that required cheap and abundant energy. ${ }^{71}$

In the 1930s the progressives of Oregon aligned around New Deal policies meant to renovate the middle class, forming the Oregon Commonwealth Federation (OCF) in 1932. In practice the OCF included local unions, the Oregon State Grange, and civil rights progressives in support of middle and working class issues. In one of their pamphlets, the OCF justified its creation by saying:

For years the well-organized forces of greed and exploitation held sway. We common people, numerically stronger, were helpless because we were divided - and KEPT divided. The justice of our cause was no match for the shrewdness and might of MONEY - at the polls, in the legislative halls, in business. $^{72}$

Each year in the spring and fall the OCF would gather together member organizations to endorse political candidates and issue resolutions.

The key goal for progressives, racially exclusive progressives and civil rights progressives alike, was to require public ownership of electricity distribution. They felt that private utility companies overcharged for electricity and were uninterested in providing rural service. For instance, in 1934, only thirty-one percent of Oregon farms

\footnotetext{
${ }^{71}$ E. Kimbark MacColl, The Growth of a City: Power and Politics in Portland, Oregon, 1915 to 1950, (Portland, OR: The Georgian Press, 1979), p. 444.

${ }^{72}$ Oregon Commonwealth Federation pamphlet, "And Now-the Truth About the Oregon

Commonwealth Federation," Pierce Collection, University of Oregon Archives, Collection 68, Box 20, Folder 1.
} 
had access to electricity because private utilities were largely uninterested in the capital outlays required to spread service. ${ }^{73}$ This severely hampered the property values of farmers and limited their operations, leading them to oppose the monied interests prevalent in Oregon politics and stand shoulder-to-shoulder with labor groups in the fight for public power under the Oregon Commonwealth Federation.

Pierce gained the support of the OCF because he had long been an advocate for public power, calling for expanded service and cheaper electric rates. In a 1938 speech he said: "Throughout my legislative career, I have recognized the principle of public benefit, and have advocated the utilization of water power for the benefit of all people." ${ }^{74}$ During Pierce's term as United States Congressman from 1932 to 1942, he introduced a number of bills in support of fair distribution of power. One of his most ambitious was HR 6387 in 1937, designed to require half of the electricity produced by Columbia River dams to go to public utilities and cooperatives. The Franklin D. Roosevelt administration supported the bill, but Governor Martin and Oregon business interests denounced both Pierce and the bill, claiming it "smacked of socialism and illegal regulation of private property by the government." ${ }^{, 75}$ In this fight Pierce used the traditional progressive rhetoric of creating a system that favored the average man over the "interests" and was successful in passing the bill, which was the first step in

\footnotetext{
${ }^{73}$ Harry H. Stein, Gus J. Solomon: Liberal Politics, Jews, and the Federal Courts, (Portland, OR: Oregon Historical Society Press, 2006), 56.

${ }^{74}$ Walter M. Pierce speech, "The Power Fight" 1938, the Pierce Papers, University of Oregon Archives, collection 68, Box 10, Folder 14. Also cited in McCoy, 403.

${ }^{75}$ McCoy, 405.
} 
creating a public regional power authority along the lines of the Tennessee Valley Authority. ${ }^{76}$

The key Portland leaders of this grass-roots movement were lawyer Gus J. Solomon and Monroe Sweetland, both notable for their social justice advocacy in the postwar period. Solomon, a highly idealistic young Jewish attorney, was one of the few attorneys in the business friendly Portland legal establishment willing to give up other business to support the creation of rural cooperatives. In some cases he even lost money. For instance, starting in 1935, Solomon represented the Northwest Public Power Association for three years in their attempt to set up rural public utility districts netting him only $\$ 840$. This amount averaged about a dollars worth of pay for every hour he worked for them when his office costs averaged three dollars an hour. ${ }^{77}$ Beginning in 1932, Solomon also began offering free legal advice to the Oregon State Grange, leading journalist Richard Neuberger to dub him "Mr. Public Power." Business interests, meanwhile, smeared Solomon as a communist on the radio and in the press. ${ }^{78}$ Sweetland, a young socialist and former student organizer, moved to Portland for a job with the National Labor Relations Board in $1936 .{ }^{79}$ He was considerably more radical than Solomon, advocating the "public ownership of all natural resources, utilities, banks, and monopolies."

Sweetland had long been a member of the socialist party. But by 1938 , like many other socialist progressives, he had come to support Roosevelt's New Deal

\footnotetext{
${ }^{76}$ McCoy, 406.

${ }^{77}$ Stein, 32.

${ }^{78}$ Stein, 32.

${ }^{79}$ William G. Robbins, "The Wartime Correspondence of Monroe Sweetland and Lillie Megrath Sweetland," Oregon Historical Review, Vol 110, No 1, (2010), 64.

${ }^{80}$ Stein, 61.
} 
policies after they came under attack by conservatives on the national level and Governor Martin at home. For Sweetland and Solomon, participation in the OCF allowed them political power to aid downtrodden white Oregonians, but they focused little on aiding minorities like Japanese Americans because it would strain the OCF alliance.

The OCF and other progressive groups faced a showdown in terms of public power in 1940. Buoyed by heavy union backing, the OCF redoubled its efforts to ensure public ownership. The OCF organized a series of ballot measure campaigns to establish Public Utility Districts all over Oregon, making 1940 "the high-water mark for public ownership. ${ }^{, 81}$ Unfortunately, all of these measures were defeated by the opposition campaigns headed up by the private utility companies. This resounding defeat sounded a death knell for the public power argument. Though the PUD issue remained in rural areas because of the preference clause in the Bonneville Power Act, the public power argument was never a galvanizing force in Oregon progressive politics again. Because, as Robert D. Johnston noted, progressive politics in Oregon have always been "fragmented, fluid, and issue focused," to fray and lose political clout. Sweetland and Solomon's avenue to political influence had reached a dead end.

Solomon tried to remain active in progressive causes like the protection of civil rights, but found little support from the broader community. As Harry H. Stein notes, in these two years “Oregon's liberal organizations shrank, functioned poorly, or

\footnotetext{
${ }^{81}$ Stein, 71.

${ }^{82}$ Robert D. Johnston, The Radical Middle Class: Populist Democracy and the Question of Capitalism in Progressive Era Portland, Oregon, (Princeton: Princeton UP, 2003), 116.
} 
disappeared, and no significant replacements appeared until a group was formed to aid returning Japanese Americans in 1944. ${ }^{\prime 83}$ Organizations like the Portland chapter of the American Civil Liberties Union, for instance, had practically disappeared by 1942. Portland was a place practically devoid of civil rights activism on the eve of World War II.

\section{Pearl Harbor as Opportunity}

After Pearl Harbor, in an atmosphere of wartime hysteria, the Nikkei faced a mounting challenge to their civil and economic rights by the Portland City Council. December $7^{\text {th }}$ was traumatic for all Nikkei in Oregon, but particularly the Issei. Citizenship quickly became Japanese Americans' only commodity in proclamations to a Portland public long primed to defend white society from racial others. The run up to the war sapped the strength of groups like the American Civil Liberties Union within Oregon that had called for the fair treatment of ethnic minorities.

The lack of political leadership on the issue may not have been so catastrophic if the Nikkei would have had a legitimate political voice with which to protest the policy of internment. Eiichiro Azuma argued that following Pearl Harbor what resulted was "an amalgamation of nationalism and racism which culminated in a complete polarization between things Japanese and things American in each warring state." ${ }^{84}$ This meant the Nikkei bore a burden of proving their Americanism to the larger public, who largely coded all Japanese as disloyal in racial terms. This polarization especially marginalized the voices of the Issei. Because they were still

\footnotetext{
${ }^{83}$ Stein, 71.

${ }^{84}$ Eiichiro Azuma, Between Two Empires: Race, History, and Transnationalism in Japanese America,(Oxford: Oxford UP, 2005), 209.
} 
citizens of Japan, when the Issei publicly professed their loyalty, the public coded it as "unqualified Americanism" or pro-Japanese propaganda. ${ }^{85}$

Besides the challenge of an increasingly hostile public, the Issei also faced the indignity of watching the Japanese American Citizens League (JACL), an all-Nisei patriotic organization, distance themselves politically from them in 1941. The Nisei sought to prove their "Americaness" by espousing their support for the Roosevelt administration's policy of F.B.I sweeps. In a newspaper interview on December $7^{\text {th }}$, former JACL president Howard Nomura seemed to disown his heritage saying, "at best our position is not good—we look like Japanese and nothing can be done about it." They failed to defend the loyalty of their parents, choosing instead to report any "suspicious activities of Japanese" to the F.B.I. in order to protect the second generation's reputation. They called for fair play saying, "We can only rely on the fairness of Caucasian Americans to help us through. We're hoping they will see our status. ${ }^{.86}$

It must be noted that Portland JACL leaders viewed the Issei as a public relations liability even before Pearl Harbor. In early 1941, the Portland JACL held a series of town meetings where they debated problems of employment, conduct of

\footnotetext{
${ }^{85}$ Azuma, 209.

86 "Nisei Placed in a Tough Spot," Oregonian, 8 December 1941, p. 9. The JACL was not and is not the representative of the political goals of all Nisei, though they often claimed to be. Because this paper deals with public perceptions and ideology, the JACL plays a key role because they were the public face of the Nisei during and after World War II. Other groups emerged later that challenged the JACL for its policy of cooperation with the federal government, such as the Civil Liberties League during internment and the National Council for Japanese American Redress (NCJAR) in the 1970s. The Civil Liberties League is discussed in chapter 3. For info on NCJAR see Alice Yang Murray, Historical Memories of the Japanese American Internment and the Struggle for Redress, (Stanford: Stanford UP, 2008).
} 
various Portland Nisei groups, and increasing tensions between the "hakujin"(white)

community and the Japanese community. Nomura told assembled JACL members:

As you notice in the American paper, the JACL is coming out once in a while with Nisei loyalty as to the United States. We are doing this primarily for one purpose. You, as Japanese, regardless of whether you are Issei, Nisei, or Kibei, are grouped as one race, and whatever the Issei do, the Nisei also will profit or suffer. Now in the newspapers we are trying to say that second generation are as loyal Americans as any other Caucasian race. Rumors have reached the office that some first generation, probably under the influence of liquor, are denouncing the United States; some Kibei have said that they would not bear arms for the United States, but would bear arms for Japan. ${ }^{87}$

Nomura and other JACL leaders concluded the best chance of presenting Nisei as loyal Americans was to distance themselves publicly from the Issei. JACL leaders suggested that Nisei could prove their loyalty in a number of ways: Nisei with dual citizenship could officially renounce their Japanese citizenship; individuals could also cooperate with the FBI investigations that were gathering information on the various Nikkei community organizations by informing on individuals espousing antiAmerican rhetoric. National JACL treasurer Hito Okada concurred claiming, "Loyalty is something you can wear like a badge. ${ }^{, 88}$ Conversely, JACL readily dismissed Nisei uninterested in military or other public service due to their unequal social status in America. When one Nisei asked if it did not make sense to repatriate to Japan to live where they could be treated equally, Okada told him he did "not appreciate his American citizenship" and told him he was welcome to repatriate. ${ }^{89}$

\footnotetext{
87 “JACL Town Meeting” 14 February 1941, Town Meeting Reports, PDX JACL Collection, p. 10. ${ }^{88}$ JACL Town Meeting, p. 10.

${ }^{89}$ The JACL also held a seriously dim view of Nisei Prefectural Associations in Portland. Adopting the opinion of FBI agents, Nomura argued that "a kenjinkai [Issei prefectural association] is an instrument of the Japanese government. Because the Nisei prefectural associations also sought relationships with the Japanese consulate, Nomura compared them to the fascist German-American Bund. It was the
} 
Pearl Harbor provided a perfect opportunity for anti-Japanese progressives like Pierce and the Oregon Grange to break ranks with civil rights minded progressives by speaking out against the Japanese. Public officials in Portland used the occasion to note what they saw as the inevitability of war with Japan. For instance, former mayor and local commander of the American Legion Joseph K. Carson claimed in a statement in the Oregonian: "we have known for some days that this action that has occurred was almost certain to happen...this is an all out war against America, and victory depends on the extent to which every citizen does his or her part." Pierce concurred saying, "I have always believed we would have to fight Japan ultimately. I believe now that this attack on Honolulu and Guam will unify the nation like nothing else possibly could have done. ${ }^{.90}$ Unity, for them, was to be built on the destiny of conflict between the Japanese race and America.

The few voices that spoke up for the Nikkei before internment belonged to church groups like the Portland Chapter of the Young Women's Christian Association (YWCA). The day after Pearl Harbor, Betty Britton, Mildred Bartholomew, and Lazelle Alway of the YWCA sent Oregon governor Charles Sprague a letter praising him for his statement that he believed in the loyalty of the Nisei to the United States. They pledged aid to "these frightened young people" as they face a climate of palpable anti-Japanese sentiment and the economic difficulties of having their parents swept up

opinion of the JACL that if the Nisei were to obtain the public perception of loyalty, all such associations had to be dissolved. JACL Town Meeting, pp. 11, 13.

90 “'Oregon's Citizens Rally at Japanese Challenge to America in Pacific,” Oregonian, 8 Dec 1941, 6. 
by FBI raids. ${ }^{91}$ According to Ellen Eisenberg, a key factor in the advocacy of church and other groups was contact with the Nikkei community. ${ }^{92}$ The Nikkei had little contact with the white community because they were ghettoized in two downtown neighborhoods by groups like the Association of Oregon Apartment House Owners who claimed the commingling of different races could only lead to trouble, and could lower home values. ${ }^{93}$ The YWCA had formed a group called the girl reserves, which included Nisei girls. This was one of the few contacts between the Nikkei and white community before the war.

Soon after the Pearl Harbor incident, the Federal Bureau of Investigation (FBI) conducted raids that removed nearly every Issei community leader in Portland. The FBI abducted all of the board members of the Oregon Japanese Association, religious leaders like the reverend of the Japanese Methodist Church, and key Issei business leaders like Masuo Yasui and Umata Matsuhsima. Fifty-nine Issei, out of about 300 families in Portland, were incarcerated due to varying levels of assumed disloyalty. ${ }^{94}$ The negative effects of such raids were particularly pronounced in Portland because Portland had a high percentage of Issei within the overall Nikkei population, at 43.2 percent, greater than any other West Coast City. ${ }^{95}$

\footnotetext{
${ }^{91}$ Letter to Governor Charles A. Sprague from Portland YWCA, 8 Dec 1941, “Japanese in Oregon”, Correspondence from files of Oregon Governors, Oregon Historical Society, Portland, Oregon, Microfilm \#9, Reel 1.

${ }^{92}$ Eisenberg, 558.

${ }^{93}$ MacColl, 538-540.

${ }^{94}$ Homer Yasui, "Santa Fe Internees," Internment Camps_-Justice Dept., INS—Santa Fe NM, Subject Files, Oregon Nikkei Legacy Center Research Library.

${ }^{95}$ U.S. Congress. House. $77^{\text {th }}$ Congress, $2^{\text {nd }}$ Sess. "Findings and Recommendations on Evacuation of Enemy Aliens and Others from Prohibited Zones" Select Committee Investigating National Defense Migration, Fourth Interim Report, May 1942, House Report No 2124, 93.
} 
Arrests by the FBI spread quickly from 17 Issei on December $7^{\text {th }}$ in Portland, to 3,849 alien enemies in the United States overall by February $16,1942 .{ }^{96} 2,192$ of these were Issei, 1,266 of which were from the West Coast. These arrests clearly targeted Japanese above other groups with much larger total populations in the United States, such as Germans with 1,393 total arrests and Italians with only 264 arrests nationwide. ${ }^{97}$ In the end, the FBI arrested 59 Issei from Oregon. ${ }^{98}$ The only slightly mitigating factor in the F.B.I. sweeps was the fact that U.S. Attorney General Francis Biddle ordered local law enforcement groups to leave the detention of "enemy aliens" to the F.B.I. preventing the spread of what he called in a 1940 speech the transformation of the local cop into the "petty tyrant."

\section{Theft as Official Portland City Council Policy}

Although the general air of anti-Japanese sentiment in Portland following Pearl Harbor was not unique among West Coast cities, actions by the Portland City Council were. While the Portland Police may have been under orders to play only a supporting role in persecution of the Issei, the Portland City Council felt more action against the Japanese was necessary. On 2 January1942, Portland Chief License Inspector Joe Hutchinson brought up the issue of what to do with the liquor license applications submitted by Issei. He was inclined to reject the licenses of all applicants that listed Japan as their birthplace. He first asked the F.B.I., who declined to comment on the

\footnotetext{
${ }^{96}$ War Relocation Authority, "Pearl Harbor and the Witch Hunt," Northwest Area Final Report of the Reports Officer, circa 1946, report number unknown, "Japanese in Oregon", Correspondence from files of Oregon Governors, Oregon Historical Society, Portland, Oregon, Microfilm \#9, Reel 2.

${ }^{97}$ Pierce Papers, Collection 68, Box 29, Folder 1.

${ }^{98}$ Homer Yasui, "Santa Fe Internees," Internment Camps—Justice Dept., INS—Santa Fe NM, Subject Files, Oregon Nikkei Legacy Center Research Library.

${ }^{99}$ Francis Biddle, "Civil Liberties and the War," Address by Biddle before the Junior Bar Conference, Philadelphia, PA, 10 September 1940.
} 
issue, so Hutchison declined to accept any more Issei applications. Hutchison also forced Nisei applicants like George I. Azumano to walk down to the police bureau to be fingerprinted before receiving their license, despite the fact that they had all already passed a criminal background check. ${ }^{100}$

Mayor Earl Riley, who was closely allied with Portland business interests, welcomed the chance to go on the record in opposition to the Japanese: "Let us find out what the policy of the council is to be right now. Let us not confuse Japanese with other aliens." Councilman Fred Peterson responded, "they are on the same basis as the Germans and Italians right now. ${ }^{" 101}$ According to a message from U.S. Attorney General Biddle, legally they were. Under the Federal Alien Registration Act of 1940, all groups should have been treated the same. ${ }^{102}$ Also, as Chief Deputy City Attorney Alexander Brown reminded the councilmen, the Department of Justice had already gone on record stating Japanese nationals should not be denied business licenses. ${ }^{103}$

Riley and his allies on the council were not daunted by such restrictions. He claimed the Japanese were different from Germans and Italians because they were not eligible for citizenship. He considered Issei alone to be alien enemies. Commissioner William Bowes concurred, proposing a motion to revoke all of the licenses belonging to Issei on the grounds that being from Japan they were still "more or less loyal" to Japan and likely to be recruited as spies. Riley's testimony that night described the Issei's marginalized position as an opportunity:

\footnotetext{
${ }^{100}$ Portland City Council Minutes, 2 January, 1942, Order of Business Number 13.

${ }^{101}$ Portland City Council Minutes, 2 January, 1942, Order of Business Number 13.

${ }_{103}^{102}$ Department of Justice, Press Release, 11 Dec 1941, Pierce Papers, Collection 68, Box 29, Folder 1.

${ }^{103}$ Portland City Council Minutes, 2 January 1942.
} 
What does the council want to do? What is the reaction of our people? I see some of them have changed their names. The goods are bought and paid for and they use American names. If not sold and used it [the goods in Japanese stores] is going to require other American money to pay for it. It is wasted. That is the attitude of the government. If we refuse to license any of them, I am speaking of the Japanese only now, and the merchandise has been freed by the government, they will have to dispose of them at sacrifice, which doesn't mean anything as far as the government or the City is concerned, to somebody that can sell it at an American store, if they can sell it. ${ }^{104}$

What Riley's suggestion amounted to was the robbing of Portland Issei, so that their merchandise could benefit white, American businessmen. Riley was not only drawing a line of naturalization that excluded Issei from civil rights, but also from access to economic resources that he saw as rightfully belonging to white Americans.

According to estimates based on a postwar survey by the Portland JACL, the average Oregon Nikkei family lost $\$ 9361$ (about $\$ 124,000$ in 2010 dollars) due to their incarceration. ${ }^{105}$ In the end, the Portland City Council revoked the business licenses of 54 Issei businessmen. ${ }^{106}$

The press also legitimized calls for Japanese exclusion in 1942. However, the degree to which anti-Japanese hysteria was a product of a campaign by the press to demonize the Japanese, or an organic outgrowth, is unclear. According to War Relocation Authority reports, towards the end of January 1942 a convention of California newspapers met and determined that they would stand together to call for the exclusion of the Japanese from the West Coast. This decision also swayed key

\footnotetext{
${ }^{104}$ Council Minutes, 2 January 1942.

${ }^{105}$ Kimi Tambara, Chairman Portland Anti-Discrimination Committee, letter to Oregon Congressional Representative John W. Owynne, 21 May 1947, Anti-Discrimination Committee, PDX JACL Collection. ${ }^{106}$ War Relocation Authority, "Pearl Harbor and the Witch Hunt," 10.
} 
Portland newspapermen like Oregon Journal editor Marshall Dana to advocate for exclusion and speak publicly in favor of internment. ${ }^{107}$

The increased public outcry led Biddle on 29 January 1942 to call for the evacuation of the Japanese from industrial areas on the West Coast thought of as vulnerable to sabotage. ${ }^{108}$ His public statement and a flood of correspondence from groups like the American Legion and the Grange led the West Coast Congressional delegation, including Pierce, to meet on 2 February in the office of California Senator Hiram Johnson, a long-time leader in the California progressive movement, to formulate a plan of action regarding the Japanese living on the West Coast. ${ }^{109}$ On 13 February 1942, the impromptu commission issued a statement to President Roosevelt calling for the following:

The immediate evacuation of all persons of Japanese lineage and all others, aliens and citizens alike whose presence shall be deemed dangerous or inimical to the defense of the United States... we make these recommendations in order that no citizen, located in a strategic area, may cloak his disloyal or subversive activity under the mantle of his citizenship alone. ${ }^{10}$

Individual members of the commission, like Pierce, had long been opposed to the Japanese, but this statement signaled a new level of belligerence.

A series of congratulatory letters between West Coast congressmen suggests that their anti-Japanese sentiment needed little reinforcement by constituents. On February $14^{\text {th }}$, Pierce wrote Republican Congressman Homer D. Angell to

\footnotetext{
${ }^{107}$ War Relocation Authority, "Pearl Harbor and the Witch Hunt," 11.

${ }^{108}$ U.S. Congress. House. $77^{\text {th }}$ Congress, $2^{\text {nd }}$ Sess. "Preliminary Report and Recommendations on Problems of Evacuation of Citizens and Aliens from Military Areas" Select Committee Investigating National Defense Migration, March 19, 1942, House Report No 1911, 2.

${ }^{109}$ The degree to which Senator Johnson was a progressive along the lines of Representative Pierce lies somewhat beyond the scope of this study, but his anti-Japanese stance seems suggestive of a correlation. House Report No 1911, 2.

${ }^{110}$ House Report No 1911, 3-4.
} 
congratulate him on the stand he took against the Nisei during the commission's deliberations. In response, Angell thanked him and again urged the importance of internment to prevent "a repetition of Pearl Harbor... we cannot stand on ceremony and allow Japs professing to be citizens and maintaining dual citizenship to hide behind our Constitution and stab us in the back while we sit idly by twiddling our thumbs." 111 These letters signal an alliance based on wartime concerns and antiJapanese sentiment, or as Azuma termed the sentiment, "super-American nationalism" that functioned in tandem with racism. ${ }^{112}$ This alliance conspicuously excluded civil rights minded progressives of the OCF, such as Solomon.

The West Coast congressmen's statement urging internment signaled an official turn of the U.S. legislative branch against the Nikkei. Roosevelt must have found this message persuasive because he signed Executive Order 9066 calling for the internment of all Nikkei six days later, on February $19^{\text {th }}$. This also happened to be the same day the Portland City Council passed a resolution calling for removal of the Nikkei "irrespective of their citizenship... for the duration of the war," a stand that Pierce praised. ${ }^{113}$ In terms of Azuma's division between all things American and Japanese, the Nikkei were in the judgment of all three branches of the federal government marginalized as one-dimensionally Japanese: a dangerous, disloyal group in need of exclusion.

\footnotetext{
${ }^{111}$ Letter from Homer D Angell to Walter M. Pierce, February 16, 1942, Pierce Papers, Collection 68, Box 17, Folder 15.

${ }^{112}$ Azuma, 209.

${ }^{113}$ Letter from Portland city auditor Will E. Gibson to Walter M. Pierce sent with Portland City Council, Resolution no. 22127, February $19^{\text {th }}, 1942$, Pierce Papers, 68-17-15.
} 
Before Army officials implemented internment orders in May 1942, the growing consensus for Japanese exclusion in wartime caused trepidation amongst groups sympathetic towards Japanese Americans. The effect of political pressure for exclusion in Portland was evident in the statements of Governor Charles Sprague and testimony at the Tolan Committee hearings. Sprague, like Sweetland and Solomon, is notable for his relative silence on Nikkei civil rights until after internment. ${ }^{114}$ In response to a letter from Portland high school teacher Clarence E. Oliver who called for the protection of the Nikkei, Sprague claimed he saw the Issei mainly as farmers interested in continuing work and the Nisei of the JACL had sent expressions of loyalty he found to be sincere. ${ }^{115}$ Also, in a letter to Mike Masaoka, the national director of the JACL on 19 January 1942, Sprague vowed "to do my utmost to protect loyal Japanese Americans from molestation."116

Other correspondence indicates that Sprague was not, however, willing to translate his friendliness towards the Nikkei into condemnation of anti-Japanese rhetoric. For instance, on January $19^{\text {th }}$, in response to a letter from Anna M. Hunsaker calling for the complete removal of all Japanese from America, written the day before Pearl Harbor, he claimed it would be against the Constitution to interfere with Japanese Americans, but called for alertness for acts of disloyalty. ${ }^{117}$

\footnotetext{
${ }^{114}$ Sprague's role in aiding returning Japanese will be further discussed in Chapter 3. He later developed a friendly relationship with Japanese Consul Masayuki Harigai in 1953 and received an imperial decoration from the emperor of Japan in 1969. McKay, 355.

${ }^{115}$ Letter from Charles Spargue to Clarence E. Oliver, 8 January 1942, Sprague Papers, 76A-68. Also cited in McKay,348.

${ }^{116}$ Letter from Charles Sprague to Mike Masaoka, 19 January 1942, “Japanese in Oregon”, Correspondence from files of Oregon Governors, Oregon Historical Society, Portland, Oregon, Microfilm \#9, Reel 1.

${ }^{117}$ Letter from Charles Sprague to Anna M. Hunsaker, ibid.
} 
Sprague failed, furthermore, to condemn Hunsaker for her overt racist rhetoric or proclaim the loyalty of the Nisei as he did in letters to individuals friendly to the Japanese. By mid February, due to increased anti-Japanese sentiment in correspondence to him and in the press, and the anti-Japanese political action of the Coast Congressional Delegation, Sprague felt it necessary to write a telegram to U.S. Attorney General Biddle:

I am convinced that our people on this coast demand more thorough action for protection against possible alien activity particularly by Japanese residing on coast. I do not believe measures now being taken are adequate and urge further and prompt action to remove this menace and recommend internment. We want no repetition of the Honolulu experience here. Recommend your agents confer with military and police authorities to plan positive protection for Americans, with decent treatment of Japanese."118

The statement was also published in the Oregonian. ${ }^{119}$ One reason for Sprague's statement was a new challenge to his re-election by conservative Republican Earl Snell. Reading the political winds, Sprague chose not to advocate for the Nikkei civil rights question in his second gubernatorial campaign, a choice he would later come to deeply regret. ${ }^{120}$

Following Executive Order 9066, Roosevelt charged a U. S. House committee investigating migration caused by war industries, with polling West Coast communities before the internment order went into effect. Congressman John H. Tolan headed the committee; the hearings beginning on 21 February in San Francisco and

\footnotetext{
118 The "Honolulu experience" referred to here is the bombing of Pearl Harbor. Charles A. Sprague, telegram to United States Attorney General Francis Biddle, Feb 17, 1942, Oregon Historical Society Archives, Portland, Oregon. Gov. Selected Files of Governors Relating to Japanese in Oregon, Microfilm No. 9, Reel 1.

119 Oregonian, 18 Feb 1942, 1.

${ }^{120}$ McKay, 352.
} 
arriving in Portland on 26 February were generally referred to as the Tolan hearings. ${ }^{121}$ The Tolan Committee hearings served legitimize of Executive Order 9066. While the Committee called for decent treatment of the Japanese and protection of their property, Tolan claimed, "This is secondary to the safety of the nation.",122 Although elsewhere the Tolan Committee supported progressive issues such as labor rights, the committee did not consider the civil rights of Japanese important enough to interfere with national security efforts.

Leaders in the 1945 debate over the return of Japanese Americans were notably absent at the Portland Tolan hearing. McKay notes that the Tolan hearings in Portland would have been an ideal venue for Sprague to come out in support of Japanese Americans as he eventually did strongly in $1944 .{ }^{123}$ For Pierce, it could have been an ideal venue for him to espouse his call for Japanese exclusion, a cause he was avidly involved in by 1944 . He was in Oregon at the time, but according to his wife Cornelia, it was because his only son had died. ${ }^{124}$ Solomon was one of the few Portland leaders of the defunct OCF who wanted to stand up for Japanese Americans. His problem was a lack of allies. Solomon spoke out at a Portland meeting of the American Jewish Congress with the argument that Jews would be next if they did not speak out against the internment of the Japanese Americans, but he found no support because his Jewish audience did not want to appear unpatriotic. ${ }^{125}$

\footnotetext{
${ }^{121}$ House Report no 1911, 4.

122 Oregonian, 28 Feb 1942, 4.

${ }^{123}$ McKay, 354.

${ }^{124}$ Letter from Cornelia Marvin Pierce to Edwin C. Matthias, Pierce Papers 68-17-15.

${ }^{125}$ Stein, 76. Stein also notes that Jews on the West Coast succeeded in part due to allegiance to the white majority, an allegiance that they did not want to tarnish by supporting the Nikkei.
} 
The only figure to speak out publicly against the policy of internment of the Nikkei was a former missionary to Japan, Azalea Emma Peet, daughter of Portland's infamous purity crusader Lola Baldwin. She spoke not as a representative of any particular organization, but as an individual. ${ }^{126}$ She claimed the Nikkei were law abiding and upstanding members of the community, making no distinctions between Japanese with or without citizenship. Because of her extensive contact with Nikkei, she was willing to stand alone in opposition to Roosevelt administration policy, antiJapanese progressives such as Pierce and the Oregon Grange, Portland businessmen leaders, the Portland City Council, the governor, and patriotic groups like the American Legion.

The Tolan Hearings were a missed opportunity for civil rights progressives Sweetland and Solomon, YWCA leaders, and Sprague to protest Nikkei incarceration. Japanese American testimony was severely marginalized, leaving them with little power to protest their internment in the face of prevalent racial nationalism. The public power issue in the prewar progressive alliance is key to understanding why, as Eisenberg notes, only an unaffiliated missionary stood up for Portland Nikkei. In the 1930s two strands of progressives--racially exclusive progressives, such as Pierce, representing the old guard and civil rights progressives, such as Sweetland and Solomon, representing the new guard--with widely divergent views on civil rights for the Nikkei, came together in the Oregon Commonwealth Federation to fight for the public distribution of electricity and Roosevelt's New Deal policies. OCF progressives such as Sweetland and Solomon served as organizers of a progressive block of voters

\footnotetext{
${ }^{126}$ Eisenberg, 542.
} 
until a series of ballot measure defeats in 1940 spelled the end of the statewide public power movement in Oregon. Without the driving force of public power, progressive groups largely went dormant or extinct by 1942.

After Pearl Harbor, due to both public hysteria and his long-term anti-Japanese agenda, Pierce broke ranks with civil rights progressives. He joined with the West Coast congressional delegation in recommending internment of all West Coast Nikkei for the duration of the war. Roosevelt then gave racial exclusion his stamp of approval on 19 February 1942 when he published executive order 9066. Internment in one sense was a heightening of the persecution of Issei as alien enemies by the F.B.I at the behest of Roosevelt's attorney general Francis Biddle. The role of alien enemies had been under serious debate in U.S. Congress since at least 1938, and the frame for the debate had long been the accepted difference between citizens and non-citizens. This division was key because it affected the views of even pro-Nikkei leaders like Sprague, who acquiesced to federal authorities who targeted the Issei above other alien groups, but spoke to the loyalty of the Nisei until internment seemed inevitable. The designation of alien enemy also allowed the Portland City Council to single out the Issei when Mayor Riley called for revoking Issei business licenses.

By the February 1942 Tolan hearings in Portland, Roosevelt administration policy largely aligned with calls from racially exclusive progressives like Pierce and the Oregon Grange. Due both to a lack of institutional support and palpable antiJapanese sentiment in Oregon, potential advocates for Nikkei constitutional rights were marginalized. Solomon, a key supporter of the Japanese by 1944, found no allies in his calls for prevention of internment. The lack of progressive civil rights advocacy 
for the Nikkei due to the absence of the organizing force of the public power debate was a main reason why no groups and only Peet spoke out against internment in Portland. 


\section{Chapter 3: "Despite Race, Color, or Creed"}

On 9 January 1944, more than eight months before the end of the Pacific War, Ted Hachiya was one of the first Japanese Americans to return to Portland. For Hachiya, coming back to his family business, a hotel in downtown Portland, involved more than a reevaluation of accounts and tenants. Returning to Portland meant renegotiating an identity acceptable to the majority white community. The Japanese community had vanished from Portland in 1942 and it was not certain if their return, in practice, would be allowed, despite U.S. Supreme Court and Army decisions in December to bring internment to a close. ${ }^{127}$

Not long after his return, Hachiya spoke to a reporter from the local newspaper, the Oregonian. Hachiya said the return of Japanese Americans to the West Coast would be difficult, especially for those without homes or businesses to which to return. However, he largely portrayed relocation in a positive light. He claimed that wartime relocation programs had been beneficial to the Nisei because the "opportunity" had offered training in new trades and a chance to travel around the United States. Continuing with his affirmative story of the Japanese American incarceration, Hachiya

\footnotetext{
${ }^{127}$ Secretary of the Interior Harold Ickes, the Presidential cabinet member in charge of the internment camps, called on President Franklin D. Roosevelt as early as 26 May 1944 to release Japanese Americans from War Relocation Authority camps, but was rebuffed for fear of a political backlash during Roosevelt's 1944 run for reelection. By October 1944, it became increasingly clear that that the U.S. Supreme Court cases like Exparte Endo would overturn Executive order 9066, Roosevelt's order authorizing Japanese incarceration. The day defore the decision came down on 18 December 1944, General Henry Pratt issued Public Proclamation No. 21, signaling the end of Japanese incarceration. Specific orders of exclusion were lifted on 2 January 1945, beginning the slow process of West Coast resettlement. See Greg Robinson, A Tragedy of American Democracy: Japanese Confinement in North America, (New York: Columbia UP, 2009), pp. 251-252.
} 
shared an anecdote about his return to Portland that reflects Nisei strategies for acceptance during the return period.

On the way to Portland on a bus I met several servicemen...I told them I was an American-born Japanese and they were most friendly with me. At one small town between Pendleton and Hood River, a soldier and I got out when the bus stopped and a fellow came up to me [sic] if I was a Jap. I told him I was an American of Japanese ancestry. The soldier took my side and asked the fellow what difference it made. The soldier said I was an American just the same as he was. ${ }^{128}$

Hachiya used the testimony of American soldiers to legitimize his claim to fullfledged American citizenship. For Hachiya, and other returning Japanese Americans, association with the Army, in large part through the story of the Nisei $442^{\text {nd }}$

Regimental Army Combat Team, became a gateway to establishing acceptance within the larger community.

In the return period, Japanese Americans embraced the Nisei patriotism argument because Portland had changed in their absence. During the war, class politics between progressives and business interests gave way to a fierce public debate over the boundaries of American citizenship. More specifically, two alignments emerged in wartime Portland over whether to aid returning Japanese Americans, or to exclude them entirely. These two groups correspond ideologically to Gary Gerstle's conception of racial versus civic nationalism. Gerstle argued that American history during the twentieth century was defined by a conflict between civic nationalism, defined as democratic universalism embracing rights of equality and liberty despite

128 “Relocation Benefits Told,” Oregonian, 15 January 1945, 5. 
heritage, and a racial nationalism that saw Americans as "held together by common blood and skin color and by an inherent fitness for self-government.",129

During World War II, racially exclusive progressives, like Congressman Walter M. Pierce, turned away from issues of class conflict in order to create a broader coalition supporting Japanese exclusion, fronted publicly by the American Legion and the Japanese Exclusion League. These anti-Japanese groups embraced a racial definition of citizenship that excluded Japanese Americans and attempted to publicly brand Japanese Americans as a racial, financial, and physical danger to the United States. When compared to the earlier racially exclusive progressivism, Japanese exclusion during World War II was no longer legitimized by attempts to improve the status of working class white Americans, but rather by the need to exclude Japanese understood as a racially monolithic group who were inherently subversive to the American way of life.

By 1943, however, prominent civic leaders, church councils, and news editors in Portland began to abandon their silence because of increasing anti-Japanese rhetoric, congressional memorials, and threats of violence. The choice by the YWCA, the Portland Council of Churches, and other civic leaders to protest anti-Japanese Oregon House memorials 8 and 9 in 1943, vandalism of the Japanese Cemetery in Portland, and attempts by the Hood River American Legion to brand Nisei soldiers as unAmerican in 1944, caused a resurgence of civic nationalism in Portland that lasted well into the postwar period. By 1945, this pro-Japanese alignment, a loose coalition

\footnotetext{
${ }^{129}$ Gary Gerstle, American Crucible: Race and Nation in the Twentieth Century, (Princeton: Princeton UP, 2001), pp. 4-5.
} 
of civic nationalists, formed the Portland Citizen's Committee to Aid Relocation, which worked in tandem with War Relocation Authority (WRA) to quell anti-Japanese activism in Portland and the surrounding areas. They were successful because they echoed the press' embrace of the Nisei Patriotism argument, which juxtaposed Nisei sacrifices to save white American soldiers in Europe with the reactionary racist antiJapanese organizers of the American Legion.

Therefore, returnees sought the aid of church groups, friendly newspapermen and lawyers, and civilian and military government officials to counteract anti-Japanese organizing efforts, rather than initiating public confrontations about the unconstitutionality of their wartime incarceration as a method of reestablishing their civil rights. These groups, referred to by Japanese American Citizens League (JACL) members as "white angels," were instrumental in easing Japanese Americans' transition back to Portland. ${ }^{130}$ At times, alliances with these groups involved the deliberate avoidance of more confrontational campaigns for civil rights. In 1945 war tensions were still high and Japanese Americans had yet to return to Portland in large numbers. ${ }^{131}$ Japanese American returnees saw a relatively smooth transition in Portland, compared to anti-Japanese intimidation in Hood River, Oregon, because Portland-based church groups won early battles in the arena of public opinion, establishing public perception of Nisei as loyal Americans.

\footnotetext{
130 "Frank Miyamoto, Interview III, Segment 16," Densho: the Japanese American Legacy Project, online archive, ID\# denshovh-mfrank-03-0016, densho.org.

${ }^{131}$ According to War Relocation Administration official Clyde W. Linville only about 100 Nisei had returned to Oregon in the first three months of return. See "Nisei Choose Other Areas," The Oregonian, 9 March 1945, 7. Also see Beatrice Stevens of the Citizens' Committee to Aid Relocation claimed only ten families of the 2,390 Japanese Americans living in Portland in early 1942 returned to Portland by April of 1945. See Beatrice Stevens, Free and Equal: The Japanese Americans in Oregon, (Portland, OR, 1945).
} 


\section{Anti-Japanese Organizing by the American Legion}

The larger Oregon American Legion organization played a key role in efforts to permanently exclude the Nikkei from Oregon. In the press and through lobbying the Oregon Legislature, the American Legion pursued its ideal of aiding "one hundred percent Americans" at the expense of Japanese Americans Former Portland Mayor Joseph K. Carson Jr. was a chief advocate for the American Legion in Portland. Before the internment of Japanese Americans in May of 1942, Carson spoke before Portland City Council and at the Tolan Committee Hearings in his capacity as Commander of the Oregon Department of the American Legion to call for the removal of all Japanese inland past the Cascade Mountains. ${ }^{132}$

Within the Legion itself, Carson led a campaign amongst other Oregon American Legion leaders to pass resolutions to the U. S Congress proposing the internment of the Nikkei until the end of the war with Japan due to the presence of enemy alien Issei in their community. He gave three reasons for this: internment would make sabotage against the war effort impossible; innocent Japanese would be shielded from vigilante violence; and, if such violence were to happen, it could "be used as a basis for reprisals against our unfortunate nationals who are in the hands of the Japanese." ${ }^{\prime 133}$ This stance on the Japanese, treating them as a racially monolithic group, was not unique, but his lobbying of other posts in Oregon was key to uniting the Oregon Department behind the banner of Japanese exclusion.

\footnotetext{
132 "Leaders Talk of Alien Peril; Oregon Dangers Discussed,"Oregonian, 27 February 1942, 15.

133 "Carson Urges Internment of Japanese," Oregon Legionnaire, March 1942, 3.
} 
Carson's successor, Hugh Bowman, took an even harder line on the issue of the return of the Japanese Americans to Oregon. Speaking at an Oregon Department convention in Portland in 1943, Bowman unequivocally stated his support of removing the Nikkei permanently. He said, "If I were to have my way, all Japs, native born or otherwise, would be disposed of entirely in the quickest way possible. It must be proven to me that there is such a thing as a Jap who is loyal to this country." ${ }^{134}$ His remarks also profoundly racialized of Japanese Americans. For instance, he attributed the birth of the Nisei in America as a plot:

It is my studied opinion that any Jap who was or is native born, was so born for but one reason; to be able to own property for the benefit of the citizens of his or her fatherland and in the end for the final benefit of that fatherland when the showdown which was bound to come, finally did come. ${ }^{135}$

Bowman subscribed to the idea that one's race and sense of nation were both linked and immovable. To him the Japanese, at home and abroad, would stop at nothing to aid their racial brothers in the Japanese Imperial Army.

Under Bowman's leadership, the Oregon Department of the American Legion pursued a legislative and ideological agenda dedicated to a postwar Oregon free of the Nikkei. At its 1943 convention, the Oregon department passed four resolutions introduced by their Americanization committee. ${ }^{136}$ These called for the deportation of "all persons of Japanese ancestry," for the U.S. Congress to limit citizenship to those

\footnotetext{
134 "Minutes of the Twenty-Fifth Department of Oregon American Legion Convention, Portland, OR, August 20-21, 1943" page 16, Mss 1511, Box 2, Folder 16, Oregon Historical Society Research Library. ${ }^{135}$ Legion Convention Minutes.

${ }^{136}$ The echoes between the Oregon Ku Klux Klan of the 1920s and the American Legion's exclusionary rhetoric as well as the way they sought to aid " 100 percent Americans" is not lost on this author. Americanization in both cases functions as a method for excluding Asians and other groups from economic and civil rights as promised in the U.S. Constitution. Because few records survived the demise of the Oregon Klan, a firmer connection between the two groups would be difficult to establish, but high membership in Portland for both groups in the early twentieth century suggests this connection would be a fruitful avenue for further study.
} 
born to U.S. citizen parents, to revoke the citizenship of Japanese Americans because they carried dual citizenship with Japan, and to support any groups that further these aims. These resolutions were designed to prevent what they saw as "further insidious infiltration, through accident of birth, of a race whose purpose is to possess, dominate, and destroy."

The Legion's anti-Japanese agenda was particularly powerful in the Oregon State Legislature thanks to the efforts of the Legion's Judge Advocate and Oregon State Senator from Portland, Thomas R. Mahoney. Mahoney had long represented Oregon Legionnaires in cases to secure preferential fishing rights on the Columbia for American citizens as opposed to foreign nationals like the Issei. ${ }^{138}$ In the 1942 debate over revoking Issei business licenses in Portland, Mahoney supported the City Council's decision because he believed Portlanders should be able to shop without worrying they could be "contributing to the coffers of enemy aliens." Furthermore, he was an outspoken proponent of putting all of Portland's Issei "behind barbed wire," following the Pearl Harbor incident. ${ }^{139}$

In 1943, Mahoney brought the American Legion resolutions to the Oregon Legislature through a pair of controversial memorials, Senate Joint Memorials 8 and 9. According to the Oregon Voter, No. 8 was a memorial petitioning the U.S. Congress

\footnotetext{
${ }^{137}$ Legion Convention Minutes, p. 32. The dual citizenship portion of this argument betrays the Legion's lack of comprehension of the actions of Japanese Americans. The JACL in Portland and elsewhere led a campaign before, during, and after the war to have its few Nisei members that had dual citizenship to renounce it. Surprisingly, these efforts were supported by the Japanese Consulate in San Francisco, who told Portland JACL leaders that they saw the Nisei as a bridge between the two countries. If the Nisei were deemed disloyal due to their dual citizenship, the bridge would have no good footing in America. For more, see "Minutes of the Portland Chapter of the JACL, 1930-1939," Sakai Collection, Oregon Nikkei Legacy Center Research Library, 14 June 1939.

${ }_{138}^{138}$ Portland City Council Minutes, 29 January 1942.

${ }^{139}$ Portland City Council Minutes, 29 January 1942.
} 
to rescind orders allowing "American-born Japs" to serve in the military. No. 9 was a memorial calling on the U.S. Congress to cancel the citizenship of all people of Japanese ancestry and deport them immediately after the war. ${ }^{140}$

Reaction by state senators to these memorials is a telling indicator of the high level of anti-Japanese sentiment in the Oregon legislature in 1943, but also reflects their cautiousness at questioning military authority. Both memorials passed votes to be considered in the legislature, but Oregon senators found the military service memorial, passed 16-14, more controversial than the deportation memorial, passed 21-9. ${ }^{141}$ Some senators argued that the military was fully capable of determining whether or not Nisei were loyal enough to serve. Fewer senators had qualms with answering the Japanese question with deportation.

Compared to representatives of other West Coast states, the Oregon Legislature was both more opposed to the return of Japanese Americans and more willing to question the wisdom of military orders. According to a Gallup pole of the coastal states, while only $31 \%$ of respondents opposed the return of Japanese Americans, 97\% of respondents approved of the Army's actions so far in reference to internment. ${ }^{142}$ Much to Mahoney’s dismay, both measures later died in committee. ${ }^{143}$ Heeding these results, Mahoney pursued anti-Japanese organizing from 1943 on with a much lower public profile.

\footnotetext{
140 “Anti-Jap Measures SJMs 8,9,” Oregon Voter, 6 March 1943, 3.

141 “Anti-Jap Measures SJMs 8,9,” 3.

142 "Return to Coast Opposed by $31 \%$ of Coast Residents, Gallup Pole Survey Reveals," Minidoka Irrigator, 6 January 1943, 4.

143 "Resolutions in the Senate," Oregon House and Senate Journal. 1943, 378-379.
} 
Ideologically, Mahoney and Pierce were close allies. One of Pierce's final acts in Congress was a profoundly anti-Japanese diatribe given in November 1942 titled “Civilization Must Win Another Contest: The Japanese Onslaught.” In this speech, Pierce portrayed all Japanese through the "yellow peril" rhetoric, depicting the aggression of the Japanese as a threat to Western civilization similar to the threats of Hannibal's armies to Rome and Genghis Kahn's horde of marauders to Europe. ${ }^{144} \mathrm{He}$ described the Japanese as "highly trained savage killers" uninterested in peace, whose untrustworthiness was finally proved by the "stab" of Pearl Harbor. ${ }^{145}$ Pierce recognized no difference between the Japanese on the Eastern and Western sides of the Pacific. He described the immigration of the Issei to America as an "invasion" representing a clear threat because of an imagined high Japanese birthrate compared to Caucasians. He said of the Nikkei, "They multiply so much more rapidly and ask so little of life...one way or another they have forced themselves into North America. They believe that the $[s i c]$ world control will ultimately pass into the hands of the yellow races, with Japan leading and making the terms." ${ }^{\text {146 }}$ Pierce's answer to this perceived threat was the deportation of all Japanese following the war.

In February of 1943, Pierce came home and began to give similar speeches all over Oregon, including a speech on 15 May to the Progressive Business Men's Club, a key business association in Portland. ${ }^{147}$ Following Pearl Harbor, the Portland Business

\footnotetext{
${ }^{144}$ Walter M. Pierce, "Civilization Must Win Another Contest: The Japanese Onslaught," Congressional Record, November 19, 1942, 49893-283, p 6830.

${ }^{145}$ Pierce, p. 6831.

${ }^{146}$ Pierce, p. 6831.

${ }^{147}$ Arthur Bone, Oregon Cattleman/Governor, Congressman: Memoirs and Times of Walter Marcus Pierce, (Portland, OR: Oregon Historical Society, 1981), 395 and "Keep Japs Out Pierce Advises," Oregonian, 15 May 1943, 7. For example of one of his speeches, see Pierce, "Some Wartime Problems,"
} 
Men's Club had been one of the few civic business groups in Portland to pass resolutions calling for internment. ${ }^{148}$ Pierce spoke before the Club in 1943 in the hopes that the influential business group would continue their opposition to the presence of Japanese Americans in Oregon, which they by means of resolution in June. ${ }^{149}$ Pierce's appearance at the meeting is an indication that his anti-Japanese sentiment was strong enough for him to put aside his anti-corporate views. Pierce consistently framed his politics around anti-corporate populist rhetoric of the "people" versus the "monopolies," and his appearance showed his desire to form a broader alliance for Japanese exclusion. ${ }^{150}$ Furthermore, his appearance demonstrated the great effect warinspired hatred of the Japanese and the American Legion's anti-Japanese organizing had on Portland businessmen.

This anti-Japanese victory was tainted, however, by the first significant public challenge to anti-Japanese efforts in Portland. E. B MacNaughton, president of First National Bank and later good friend to the Nikkei community, took this opportunity to protest "racial scapegoating" by the club, though he was unsuccessful in preventing the anti-Japanese resolution. ${ }^{151}$

The Portland Chamber of Commerce, on the other hand, needed little prodding to oppose the return of Japanese Americans. Around May 1943, the

\footnotetext{
speech given in Albany, OR 9 February 1943. Walter M. Pierce Papers, Collection 68, University of Oregon Archives, Box 74, Folder 5.

${ }^{148}$ Letter from Henry G. Kreis, Chairman of Civic Projects and Programs Committee, Progressive Business Men's Club to Oregon Governor Charles A. Sprague. 20 February 1942. "Japanese in Oregon", Correspondence from files of Oregon Governors, Oregon Historical Society, Portland, Oregon, Microfilm \#9, Reel 1.

149 "Race Prejudice Expressed in Resolutions, Oregon Voter, 19 June 1943, 3

${ }^{150}$ Robert R. McCoy."The Paradox of Oregon's Progressive Politics," Oregon Historical Quarterly 110 , No. 3. 405.

151 "Race Prejudice Expressed in Resolutions, Oregon Voter, 19 June 1943, 3.
} 
Chamber's executive council sent out questionnaires to other Chambers of Commerce and American Legion posts on the Pacific Coast to make sure Portland's Chamber came out on the right side of the issue of Japanese return. On 3 June, the executive committee learned "it was pretty much the consensus that Japanese should not be allowed to return to this area." ${ }^{, 152}$ Following suit, the executive council voted to adopt the same position. This signaled a departure from the Chamber's previous proJapanese stance. ${ }^{153}$ The Chamber's embrace of Japanese exclusion showed the influence of anti-Japanese rhetoric and organizing, but was not a reflection of the development of a growing, more general anti-Asian prejudice in Portland business circles. Only a month later the executive council voted to support the addition of Chinese people to the 1924 Johnson-Reed act's naturalization quota system that had previously barred them from citizenship. ${ }^{154}$

\section{Desecration and Conflict in the Portland Japanese Cemetery}

Although the American Legion in 1943 sought permanent exclusion of the Nikkei mainly through lobbying efforts, on at least one occasion they also resorted to threats of violence. Sometime during the summer of 1943, vandals tipped over or destroyed about 250 grave markers in the Rose City Japanese Cemetery, then set the

\footnotetext{
152 "Minutes: Executive Committee," Portland Chamber of Commerce, June 3, 1943, Mss 686-2, Folder 6, Oregon Historical Society Research Library.

${ }^{153}$ The Portland Chamber of Commerce had almost always opposed anti-Japanese bills, such as the Oregon Alien Land Law of 1923 because they believed they would give Portland a bad name in Japan, thus the $\$ 69$ million per year trade with Japan. Furthermore, a drop in trade would have also led to friction with the Sailor's Union of the Pacific, who often became restive in times of low trade and called for the exclusion of Asian sailors from American vessels. This meant that a time of low trade would also mean paying higher wages to American sailors. See Bone, p. 95. Also, "Sailor's Union of the Pacific, Japanese and Korean Exclusion League,” Minutes, 10 January 1910, Microfilm 59, Oregon Historical Society Research Library.

154،Minutes: Executive Committee," 15 July 1943, p. 2.
} 
cemetery on fire. ${ }^{155}$ On 14 August 1943, the Oregonian published an article publicizing an effort led by Reverend J. W. Reed, president of a pacifist group called the Portland Fellowship of Reconciliation, to repair damage to the cemetery, perform bonmatsuri rites, and have a pot luck at the site to discuss Portland's racial problem the following day. In the article, Reed asked Portlanders for help in cleaning up the cemetery as a way of showing their solidarity with Japanese Americans. Reed conceived of the event after receiving \$30 from Japanese Americans in Minidoka for the purpose of buying wreaths to be placed on their families' graves. ${ }^{156}$

On Saturday, Reed and others went to the cemetery and found the entrance blocked by a contingent of Legionnaires, Sheriff Martin T. Pratt, and Multnomah County District Attorney James R. Bain, who came together to stop the pacifist group because they considered it "an insult to American war dead." When Pratt threatened to arrest the pacifist group claiming fear of a riot, Reed called off the program for Sunday. ${ }^{157}$ The secretary for the national YMCA, Howard Willits, and other members of the Portland religious community returned the next day despite warnings from Sheriff Pratt. ${ }^{158}$ The police presence on Sunday escalated to twenty officers, local

\footnotetext{
${ }^{155}$ Although, it was widely believed to be the work of juvenile delinquents, Portland police officer George J. Clauss claimed the many of the large stones could not have been broken by youths. Pursinger, p. 334

156 “Aid Requested On Cemetery,” Oregonian, 15 August 1943.

157 "Sheriff Heads Off Riot By Preventing Pacifists From Honoring Jap Dead," Oregonian, 15 August $1943,17$.

${ }^{158}$ Howard Willits was there in part to keep a promise he made to Reverend Terakawa of the Japanese Methodist Church. In April 1942, he met with other members of the Portland Council of Churches to discuss aid to evacuating Japanese Americans. One key point that came up was the need to care for the Japanese cemetery while they were gone. In a letter to JACL leader Hito Okada, Willits accepted responsibility for care of the cemetery and asked him what that would entail. For Willits, cleaning up cemetery vandalism was a personal responsibility. See Howard D. Willits, National Student Secretary, Pacific Northwest YMCA-YWCA, letter to Hito Okada, National Treasurer, JACL, 15 April 1942, Military Evacuation, PDX JACL Collection.
} 
American Legion post commanders, and Portland city Commissioner Fred L. Peterson. Pratt himself opted not to show claiming that the Japanese cemetery was officially closed for the duration of the war. ${ }^{159}$ One source suggests that the Legionnaires themselves were armed, but the Oregonian does not mention this. ${ }^{160}$ However, the article mentions law enforcement on hand were friendly to the Legionnaires, making no attempt to stop their heckling. ${ }^{161}$ Willits managed to barge his way in, but once more Fellowship members showed up, heated arguments escalated to shoving and threats of bloodshed.

The deputy on the scene attempted to diffuse the situation by reiterating Pratt's ban, after which Willits demanded to speak to him. Because the deputy would not allow him to use the police radio, Willits was forced to seek a telephone elsewhere. A farcical scene ensued, with hecklers following Willits for ten blocks to prevent him from using phones in nearby businesses. ${ }^{162}$ Willits and others were ultimately unable to repair the damage to the cemetery or prevent further desecration of the cemetery by vandals in August 1944. ${ }^{163}$ The incident ended without violence or arrest, but served as a serious point of friction between Portland religious groups and the anti-Japanese, American Legion-aligned Portland leadership. This friction was surely heightened by a speech given the following week by American Legion National Commander Roane

\footnotetext{
159 "Sheriff Heads Off Riot By Preventing Pacifists From Honoring Jap Dead," Oregonian, 15 August 1943, 17.

${ }^{160}$ Beatrice Stevens, Free and Equal: The Japanese Americans in Oregon, Portland, 1945.

161 "Sheriff Heads Off Riot By Preventing Pacifists From Honoring Jap Dead," Oregonian, 15 August $1943,17$.

${ }^{162}$ Sheriff Heads Off Riot By Preventing Pacifists From Honoring Jap Dead," Oregonian, 15 August 1943, 17

${ }^{163}$ Pursinger, p. 335.
} 
Waring calling for the complete annihilation of the Japanese, a call that did not make a special exception for Japanese Americans. ${ }^{164}$

\section{The Coalition Against Anti-Return Groups}

No Portland religious, business, or academic group staged significant opposition to Nikkei incarceration in 1942. In 1943, Portland religious groups, such as the Council of Churches and the YWCA, were the first to fill that void publicly in a way that could provide real benefits for Japanese Americans. Through a series of public statements in response to anti-Japanese organizing, members of the Portland community inclined to support Japanese Americans' right to return began to organize, beginning with the previously mentioned Portland cemetery incident.

The Portland chapter of the YWCA was perhaps the first to address publicly the injustice of internment. In early May 1943, Ruth W. Kingman of Berkeley, California, spoke to a group of civic leaders at the YWCA in the hopes of forming a Portland chapter of the Committee on American Principles and Fair Play. Kingman did not call for the release of Japanese Americans, but rather sought to influence public opinion on "the Japanese problem." Whereas anti-Japanese groups saw the "Japanese problem" as the threat people of Japanese descent posed to the livelihood of the white majority, the Fair Play Committee viewed anti-Japanese legislative campaigns as the true "Japanese problem." Kingman claimed:

Legislation to deprive Americans of Japanese descent of any of their legal rights would set a precedent for depriving other racial groups of their rights and would weaken the confidence of our allies, particularly those in Asia and

164 “Crush Japs, Urges Head of Legion,” Oregonian, 19 August 1943, 1. 
Latin America, in the sincerity of our professions to be fighting for the rights of all people. ${ }^{165}$

In short, Kingman was the first to state openly in Portland's press that the incarceration of Japanese Americans undermined American principles and the war effort.

It must be mentioned here that the Portland YWCA's efforts on behalf of Japanese Americans began well before World War II. As historian Mary K. Gayne observed, the Portland YWCA had several Japanese American groups, such as the Japanese Girl's Reserves. These groups were meant to instill Christian values and to integrate Japanese women into larger society as part of "efforts to achieve the interracial goals set by the national YWCA in 1919." "166 Mildred Bartholomew, Department of Religion and Membership Secretary, and Betty Britton, Secretary of the Young Women's Department supervised these efforts in Portland. In 1942, they continued their work during the incarceration period by establishing the clubs in the Minidoka internment camp, ${ }^{167}$ as well as by aiding Nikkei families through the storage of some of their personal possessions. ${ }^{168}$ Barholomew visited Minidoka in October 1942 to meet with War Relocation Officials and JACL leaders, under the auspices of visiting members of the Girls Reserve. ${ }^{169}$

Despite a long-term commitment to Japanese Americans, the Portland YWCA refrained from taking a public stance against anti-Japanese campaigning by Pierce and

165 "Racial Bias To Be Fought," Oregonian, 9 May 1943, Section 3, p 8.

${ }^{166}$ Mary K. Gayne. "Japanese Americans at the Portland YWCA," Journal of Women's History 15, No 3, 197-198.

${ }^{167}$ Minutes: Board of Director's Meeting, Young Women's Christian Association, Portland, OR, May 12, 1942, p 2. Box 9A, Folder 1, Lewis \& Clark College Special Collections and Archives.

168 Gayne, 199.

169 “Portlanders Here for Y-Tea,” Minidoka Irrigator, 10 October 1942, 3. 
the American Legion. Minutes from the YWCA Board of Directors show the board was deeply concerned about Mahoney's anti-Japanese memorials in March of 1943. In response, the board chose to issue a resolution in opposition to these memorials. The resolution was sent to other YWCA branches, but not to the Portland press. ${ }^{170}$ Other Portland church groups were much more vocal in the press. The Portland Council of Churches, the Oregon Christian Youth Council, the Oregon Council of Women, and the Portland Chapter of the International League for Peace and Freedom publicly claimed the Nisei were a "truly American" group because of their "hard work, thrift, purchase of land and education." ${ }^{\prime 11}$ While the precise reason for the YWCA's restraint is unclear, it seems likely that the board was reluctant to speak because they were waiting for word from the national organization.

National YWCA representatives wished to remain neutral on the issue in the interest of preserving their relationship with the War Relocation Authority (WRA), the wartime agency within the Department of the Interior that supervised the internment camps. The YWCA was one of the few groups allowed to operate in the WRA camps along with the Red Cross, the USO, and handful of others. ${ }^{172}$ In the press, the YWCA maintained a low profile so as not to give fuel to American Legion calls to return the camps to Army control, which both groups believed would have dealt more harshly

\footnotetext{
${ }^{170}$ YWCA Minutes, 9 March 1943.

171،"Defeat of Memorials Aim of Church,” Minidoka Irrigator, 20 March 1943, 3.

${ }^{172}$ Relations with Minidoka administrators were so close that the orientation of staff generally included a lecture by an Executive Secretary of the YWCA or its brother group the YMCA. "Pertinent Facts About Relocation Centers and Americans of Japanese Ancestry," War Relocation Authority, 23 Nov 1944. Ikeda Family Collection, Densho Archives. Online denshopd-p72-00041, p.1. See also, Constance Kimmerling. "Report of the Welfare Section," 28 Feb 1945, Minidoka Relocation Center, Introduction, Section A, Japanese American Evacuation and Resettlement Records, 1930-1974. Bancroft Library MSS 67/14.
} 
with Japanese Americans. Thus any organization aiding Japanese Americans in the camps had to mute its advocacy in the press.

There is also evidence that the YWCA's diplomatic approach was strategic in that it allowed them to seek favors for certain Nisei. For instance, two weeks after Bartholemew's visit to Minidoka in October 1942, Frances Maeda became one of the first two internees to be released for employment outside of the exclusion zone. ${ }^{173}$ Maeda had served under Bartholomew's committee at the YWCA in a vital role as liaison with the Japanese Methodist Church. ${ }^{174}$ Such favoritism was more the exception than the rule because such releases engendered significant resentment on the part of Nisei eager to seek opportunities in business and education outside of the internment camps. ${ }^{175}$

By avoiding controversy, the National YWCA was able to seek a broader effort to aid Nisei through the creation of a committee of West Coast college presidents, educators, students, and clergy to arrange transfers to colleges in the East in March and April of 1943. In May 1942, the program of school relocation run by the National Japanese American Student Relocation Council became the first program designed to mitigate the effects of internment on the Nisei. ${ }^{176}$ The program found colleges willing to accept Nisei students and helped support their studies financially.

\footnotetext{
173 “Two Given Indefinite Leaves for Work, First on Record,” Minidoka Irrigator, 24 Oct 1942, p. 1.

${ }^{174}$ Gayne, p. 199.

${ }^{175}$ John Tateishi, And Justice for All: An Oral History of the Japanese American Detention Camps. (Seattle, WA: University of Washington Press, 1999), 74.

176 "From Camp to College: The Story of Japanese American Student Relocation," Philadelphia, PA: National Japanese American Student Relocation Council, 1945. Tambara Collection, 53/77 \#2002.26, Oregon Nikkei Legacy Center Archives.
} 


\section{Other Silences}

The pressure to remain silent in the face of anti-Japanese sentiment could be even stronger for Japanese Americans loudly demanding recognition of their constitutional rights. Portland's most outspoken Nisei challenger to orders of internment was a lawyer, the only Japanese American to have been admitted to the bar before World War II, Minoru Yasui. ${ }^{177}$ Yasui was the son of a prominent Hood River Issei businessman Masuo Yasui, who like Daiichi Takeoka and other influential Issei, had been arrested by the FBI in early 1942 prior to internment orders. When General John L. DeWitt placed a curfew on all people of Japanese descent in zones including Portland, Yasui challenged the order in court based on his conviction that no "military authority has the right to subject any United States citizen to any requirement that does not apply equally to all other citizens." ${ }^{, 178}$ The day the orders went into effect, he walked up to a police officer and insisted on being arrested. In connection with his test case, Yasui was escorted from the Minidoka internment camp to the Multnomah County jail in downtown Portland in November $1942 .{ }^{179}$ Yasui spent nearly a year in solitary confinement awaiting the determination of his appeals, with almost no visitors.

Despite limited contact, Yasui was aware of anti-Japanese organizing in Portland. Writing to the editor of the Minidoka Irrigator, Yasui was the only Oregon Nisei willing to engage Pierce's racially exclusive rhetoric publicly. He called Pierce's spurious public warnings about supposedly high Japanese birth rates merely "an echo

\footnotetext{
${ }^{177}$ Tateishi, p. 65.

${ }^{178}$ Tateishi, p. 70.

${ }^{179}$ Tateishi, p. 77.
} 
of previous cries of yellow peril." Yasui denounced Pierce for his racial definition of Americans writing:

His concluding statements mark him as a race hater, and as an un-American demagogue. The issue ought not to be whether the Pacific Coast should remain "white" or "yellow." The issue ought to be whether the Pacific Coast will remain American or degenerate into a land of "superior whites." I believe Pierce would be willing to destroy Americanism for sake of "white man's" superiority. 180

This statement is the most direct refutation of Oregon racism in the press at the time, even when compared to the Minidoka Irrigator's own coverage of Pierce. ${ }^{181}$

Fearing a backlash, the national Japanese American Citizens League (JACL), which had its own beneficial relationship with the WRA, condemned Yasui's protests as part of its policy of saving civil rights advocacy for the postwar period. In 1943, the National JACL public relations spokesman Mike Masaoka condemned Yasui and other "self-styled martyrs" who sought to test army curfew orders. His statement included ten reasons to condemn Yasui's actions, including the belief that the first duty of all Americans was to obey Army orders, the argument that such test cases would be better pursued after the war, the conclusion that cooperation with evacuation orders did not compromise civil rights, and the insistence that such cases provided a focus point for anti-Japanese editorialists seeking to brand all Japanese as "treacherous and dangerous. $" 182$

\footnotetext{
${ }^{180}$ Minoru Yasui, letter to the editor, Minidoka Irrigator, 1 May 1943, 4.

${ }^{181}$ The Irrigator, which was both sponsored and censored by the (WRA), reported on Pierce's antiJapanese diatribes, but refrained from casting any judgment on them. "Former Governor of Oregon Urges Ousting of Aliens," Minidoka Irrigator, 1 May 1943, 2.

182 "Opposition of National JACL to All Test Cases Explained by Masaoka," Ikeda Collection, Densho Online Archive: denshopd-p72-00039.
} 
Paul Spickard and other historians have noted that JACL aims during the war era included attempts to establish its leadership in the Japanese American community and to foster positive relations with government agencies, an effort that predated Pearl Harbor. ${ }^{183}$ The 1943 JACL memo supports that view: Masaoka avoided confronting anti-Japanese sentiment so as not to endanger a beneficial subordinate role vis-a-vis Army and WRA authorities.

This memo was also part of a larger effort to maintain legitimacy for the JACL among the larger Japanese American community. As Spickard wrote, strikes by Nisei at Poston and other WRA camps condemned JACL leaders for their collaboration with government authorities, leading to a series of beatings of JACL leaders such as National President Saburo Kido. ${ }^{184}$ In the wake of such violence, new groups became more influential in many internment camps. In Minidoka, one such group was the Civil Liberties League (CLL). Nisei interested in challenging military orders, such as Portlander George Tani, formed CLL after Minoru Yasui was taken from Minidoka to stand trial in Multnomah County Court. Their stated purpose was supporting Yasui in any way possible, while spreading word of his civil rights efforts. ${ }^{185}$ Thus, when Masaoka warned in the opposition memo "should we challenge...travel restrictions we might be damned as fifth columnists," he sought to undermine the legitimacy of rival Nisei groups. In response, the Civil Liberties League maintained their support for Yasui, but divided donations between a fund for general activities and the Min Yasui's

\footnotetext{
${ }^{183}$ Paul R. Spickard, “The Nisei Assume Power: The Japanese Citizens League 1941-1942," Pacific Historical Review 25, No 2 (May 1983), 158.

${ }^{184}$ Spickard, 170.

185 “Advertisement for a Civil Liberties League Meeting," Commission on Wartime Relocation and Internment of Civilians Collection, University of Washington Special Collections, Microfilm A7378, Reel 7, Box 7, Frame 244, Item 7743. Accessed via Densho online archive: denshopd-i67-00109.
} 
Case Fund, giving supporters the option to donate money to CLL efforts without directly supporting Yasui. ${ }^{186}$

\section{Civic Leaders Speak Out}

Outside of Minidoka, Yasui found little public support for his case, but was joined in his condemnation of Pierce by two other Oregon figures, Portland banker E. B. MacNaughton and former Governor and newspaper editor Charles Sprague. Their willingness to denounce anti-Japanese sentiment in Portland helped to rally church groups and made them natural spokesmen for the emerging pro-Japanese alliance. As mentioned above, MacNaughton's protest of the Portland Business Men's Club's 1943 anti-Japanese resolution was unsuccessful in preventing the resolution from passing. However, his opposition gained the approval of church groups in Portland such as the committee on International Justice and Good Will of the Council of Churches, which was interested in repealing anti-Asian laws like the Oriental Exclusion Act of $1882 .{ }^{187}$

Sprague, having lost a gubernatorial primary against Earl Snell in 1942, returned to his editorial position at the Oregon Statesman. Between 1943 and 1945, this editorial page became the public voice of the clash between anti-Japanese and proJapanese groups. In 1943, in one of what would become many articles on the right of Nikkei to return to Oregon, Sprague claimed internment was not "creditable to American standards" and that Mahoney's proposed memorial in the Oregon legislature, to deport Japanese Americans whom Sprague considered loyal to the United States,

\footnotetext{
186 “Civil Liberties League,” Civil Liberties League 1942, Box 1, Japanese American Citizens League History Collection, Japanese American National Library Archives.

187 “Exclusion Act Repeal Urged By Portland Groups," Minidoka Irrigator, 31 July 1943, 2.
} 
was an affront to American considerations of fair play. ${ }^{188}$ Soon after, Pierce began writing editorials in response that reveled in the "rabble-rouser" status with which Sprague had labeled him. The resulting battle of articles won sympathy for both sides, ${ }^{189}$ most importantly causing the Portland Council of Churches to see Sprague as an important advocate for the Nikkei community. ${ }^{190}$

\section{The Hood River Effect}

By late fall 1944, Supreme Court cases challenging the constitutionality of the Japanese incarceration appeared more and more destined for victory with the likely result of a lifting of exclusion orders before the end of hostilities with Japan. Frustrated by legislative defeats, and interested in keeping Japanese American farmland, the Hood River American Legion redoubled its efforts to portray Japanese Americans as racially ineligible for citizenship. On 29 November 1944, the Hood River post removed the names of sixteen Nisei soldiers from a plaque honoring Hood River servicemen, a public demonstration of the post's belief that Nisei soldiers fought for reasons other than loyalty to the United States. Post officials claimed Nisei soldiers had dual citizenship with Japan, and thus were loyal to Japan. ${ }^{191}$

To explain the removal, Hood River Post commander Jess Edington produced a ten-page pamphlet, a manifesto for the anti-return movement in Oregon. The pamphlet described Japanese immigrants as covetous of the "Pacific slope with all its wealth." They were part of a conspiracy "to take up the old sure game of infiltration

\footnotetext{
188 “Move To Deport Japanese Rapped by Salem Paper,” Minidoka Irrigator, 20 March 1943, 3.

${ }^{189}$ For an example of an account sympathetic to Pierce, see "The Japanese Peril," Postmaster's Gazette, February 1944, pp. 31, 33.

190 “Exclusion of Japanese Topic of Oregon Paper," Minidoka Irrigator 24 March 1945, 1.

191 Tamura. 216.
} 
by reproduction, looking forward to the time that they will again bid for domination of the Pacific Area." ${ }^{192}$ Using little in the way of evidence, the pamphlet claimed that Japanese diminished property values and that, to avoid the "Japanization" of Hood River Valley, the Oregon 1923 Alien Land Law should be enforced, codicils on all Hood River real estate should ban the sale of property to Japanese, and a corporation should be set up to buy up all remaining Japanese owned property. ${ }^{193}$ Striking out against defenders of Japanese Americans, the pamphlet also blamed the Pearl Harbor incident and U.S. casualties in the Pacific on the "ministerial associations, pacifists, and enemy agents" who defeated the 1920s American Legion effort towards universal military service. ${ }^{194}$

The Hood River post's actions provoked an almost immediate response among civic nationalists in Portland, and brought a storm of negative press on Oregon and the American Legion. Coincidentally, Roger Baldwin, national director of the American Civil Liberties Union, happened to be speaking to the Portland City Club on 1 December, two days after the name removal. ${ }^{195}$ Baldwin had been less than supportive of Japanese American civil liberties skirmishes and was coming to give a speech claiming civil rights had fared much better in World War II than it had in World War I. $^{196}$

Conversation following Baldwin's speech turned to the Hood River removal. Under a withering barrage of questions, Edington announced that Hood River did not

192 “A Statement on the Japanese,” Hood River Post No. 22 American Legion, Department of Oregon. Charlie Davis Collection, Oregon Nikkei Legacy Center Archive, Box 1 Folder 41.

193، A Statement on the Japanese."

194 “A Statement on the Japanese."

195 Portland City Club Bulletin, 1 Dec 1944.

196 “Roger Baldwin Says Rights Not Seriously Infringed,” Minidoka Irrigator, 2 Dec 1944, 1. 
want the return of any Japanese Americans. ${ }^{197}$ Baldwin condemned the post saying, "I should presume that the American Legion, as a great patriotic organization should be the first to accept all veterans - regardless of race. It is a matter of great regret when race prejudice of any sort takes precedence over patriotism. ${ }^{, 198}$ Reverend H. J. Maulbestch, president of the Portland Council of Churches, echoed Baldwin's criticism, warning of "serious consequences in Asia if we permit race prejudice to govern our actions. ${ }^{, 199}$ Shortly after the City Club meeting, Baldwin sent Gus Solomon, the Oregon ACLU representative, a letter urging him to file a case testing the constitutionality of a quadriplegic Nisei veteran returning to Hood River. ${ }^{200}$ The news in Hood River provoked both public condemnation and a renewed legal effort to aid Japanese Americans in Portland.

The City Club meeting also indicated to some American Legion officials that anti-Japanese rhetoric could have political consequences. Mahoney, present as a representative of the Oregon Department of the American Legion, was suddenly backed into a corner. Church groups in Portland had vocally opposed anti-Japanese memorials he introduced in 1943, but saved the majority of their criticism for the memorials themselves, rather than for Mahoney personally. ${ }^{201}$ Forced to make a statement that was certain to be published in Portland newspapers, Mahoney

\footnotetext{
${ }^{197}$ Ibid.

198 "Churches Rap Legion Act," Oregonian, 4 Dec 1944, 1.

199 "Race Feeling Under Attack," Oregonian, 4 December 1944, 11.

${ }^{200}$ Gus Solomon Oral History, Oregon Jewish Museum, Tape 6, Side 1.

201 "Women Oppose Jap Deportation," Oregonian, 5 March 1943, 5.
} 
equivocated. He refused to condemn the Hood River post publicly, but claimed that "such action was up to individual posts," and more removals could follow. ${ }^{202}$

The name removal soon became a nationwide issue leading to an embrace of civic nationalism and demonization of racial exclusion in Portland. Articles in newspapers across the country reported outrage at the Hood River post's honor roll removal, placing increased pressure on the national American Legion to disavow the removal. Secretary of War Henry Stimson called the removal "Not consistent with democratic ideals," reinforcing the notion that Nisei soldiers had proven their loyalty and valor in combat in Italy. ${ }^{203}$ Assistant Director for the WRA and American Legion member Robert D. Cozzens claimed "I know that your disgraceful act cannot be condoned by a vast majority of American Legionnaires...nor by the lost battalion rescued in the war by Nisei...you have betrayed the Legion." 204

Soldiers writing from the front joined Cozzens and Stimson in response to a Stars and Stripes article on the removal. ${ }^{205}$ Many bristled at the possibility of being described as "missionaries for Jap hating." One Captain from Hood River claimed that if the Nisei names were not restored, he wanted his removed. ${ }^{206}$ Oregonian Sgt. J. B. Jones wrote from France "people back home ought to know that if it wasn't for the Nisei, a lot of their sons would be dead now. ${ }^{207}$ Jones refers here to the $442^{\text {nd }}$ combat

\footnotetext{
202 "Churches Rap Legion Act," Oregonian, 4 December 1944, 1.

203 "War Secretary and Other Legionnaires Condemn Blacklisting of Loyal Nisei," Oregonian, 15 December 1944, 1.

204 Ibid.

205 Tamura, 218.

${ }^{206}$ Eleanor N. Forden. “Stands by Local Japanese," Oregon Journal, 12 March 1945 and "Service Men Tolerant," Oregonian, undated, but likely during March, Mizuta Scrapbook, George Mizuta, Oregon Historical Society Research Library, Microfilm 154.

207 “Front Line Soldiers Rap Hood River Legion Act,” Oregonian, 29 January 1945, Section 2, p. 3.
} 
unit's push to save the "lost battalion," in which Nisei soldiers suffered heavy casualties to save a white unit that was trapped behind German lines. ${ }^{208}$ U.S. Marine and University of Oregon History professor Harold J. Noble also told the City Club that, "the Japanese government realizes full well that these Japanese American soldiers of America are their most implacable enemies."209 A number of other American Legion posts also condemned the action; in fact one New York Post offering to put the sixteen removed names up on their honor roll. ${ }^{210}$ Such articles created a dialectic between racial antagonists at home and the valor of Japanese Americans abroad that became a powerful argument for the loyalty of Japanese Americans. The public was willing to accept anti-Japanese sentiment to a point, but questioning the loyalty of American soldiers was beyond the pale.

The confrontation at the City Club and later negative press curtailed some of Mahoney's less-public anti-Japanese organizing. In 1944, Mahoney became involved with the American League of California, a newly formed anti-Japanese organization of produce dealers and flower merchants based in Los Angeles. The League created a Council on Alien Relations, whose articles of incorporation benignly describe itself as a corporation interested in the buying and selling of various forms of property by U.S. citizens "who are interested in aliens." The Council's list of objectives however, shows that it called for standard anti-return aims. For instance, the Council called for preventing the return of Japanese Americans and the deportation of disloyal Japanese Americans "under special treaty arrangements." Mahoney sat on the board of

\footnotetext{
${ }^{208}$ Ibid. The $442^{\text {nd }}$ Combat Unit was the all-Nisei unit created from the Hawaiian National Guard members and volunteers from WRA camps.

${ }^{209}$ Oregon Voter, 23 December 1944, 4.

210 “N. Y. Legion Will Accept 16 Soldiers,” Oregon Journal, 23 December 1944, Mizuta Scrapbook.
} 
governors of that council and had suggested that Pierce serve as well. W.W. Gray, writing for the council, assured Pierce that all activities would "be along dignified lines" so as not to bring condemnation on members. ${ }^{211}$

In November 1944, Mahoney was also involved in the formation of Oregon Anti-Japanese Incorporated in Gresham, a rural suburb of Portland. A grocer named Ralph Hannan, the mayor of Gresham, H. H. Hughes, and attorney C.G. Schneider, founded Oregon Anti-Japanese Incorporated with the purpose of promoting an amendment to the state constitution to bar the return of Japanese Americans to Oregon. ${ }^{212}$ This group had the backing of Mahoney, who formed a sister group in Portland with the intention of making Oregon Anti-Japanese Incorporated a statewide organization. $^{213}$

Oregon Anti-Japanese Inc was distinctive for its incendiary rhetoric. Speaking to an Oregon Journal reporter, an organizer for Oregon Anti-Japanese Incorporated warned of violence towards Japanese Americans in Oregon if they were allowed to return. Telling a tale of narrowly averted violence, Price said a Japanese American, out on permit from Tule Lake, had visited a farm belonging to a World War II veteran. As Price told it, "the infuriated veteran immediately chased after the Japanese" with a knife he had been using to cut cauliflower. ${ }^{214}$ This implicit threat betrayed the meaning behind Oregon Anti-Japanese Inc.'s stated purpose to "get this job [Japanese

\footnotetext{
${ }^{211}$ Letter from W. W. Gray Secretary-Treasurer American League of California to Walter M. Pierce with accompanying articles of incorporation, statement of objectives, 8 January 1945, Pierce Collection, 68-16-8.

212 “Group Organizing Against Japanese,” Oregonian, 28 November 1944.

213 "Protests Rise as Japanese Try to Regain Land,” Oregonian, 30 December 1944.

214 “Gresham Groups Organizes to Oppose Return of Japs,” Oregon Journal, 28 November 1944.
} 
exclusion] done before the boys come back, because if we don't do it, the returning servicemen will.",215

The articles provoked a response by the Oregonian's editorial board. The board called the reasons for organizing Oregon Anti-Japanese Inc. "economic, not patriotic" in that they sought to prevent future competition in agriculture. ${ }^{216}$ Furthermore, they took the group to task for its "unwarranted assumption" that soldiers would attack returning Japanese Americans. Gresham businessmen and farmers, the board said, had no right to speak for soldiers fighting abroad, some alongside Nisei soldiers in Italy and France. ${ }^{217}$ This marked a turning point for the Oregonian editorial board, which had previously racially denigrated all Japanese without distinguishing between citizens of Japan and Japanese Americans. ${ }^{218}$ The Oregonian strengthened their stance two weeks later proclaiming, "the great law abiding majority of Oregon citizens will not tolerate persecution of the Japanese minority. They will not countenance the return of the Ku Klux Klan."219

\section{Portland's Pro-Nisei Alignment}

Once the settlement era began in earnest after 17 December 1944, plans by Portland church groups, civic leaders, and War Relocation Authority officials for the return of Japanese Americans began to take form. On 30 November 1944, the Portland YWCA received a letter from the Chairman of the YWCA's Western Regional

\footnotetext{
215 “Gresham Groups Organizes to Oppose Return of Japs,” Oregon Journal, 28 November 1944.

216 “Our Japanese Problem,” Oregonian, 3 December 1944, p. 18.

217 “Our Japanese Problem,” Oregonian, 3 December 1944, p. 18.

${ }^{218}$ For instance, in "Those Highly Sensitive Japs," the board claimed "what monumental chumps we were to think that a prevailing majority of you [Japanese] were actually civilized." Oregonian, 6 February 1943.

219 “The Challenge," Oregonian, 19 December 1944, 6.
} 
Council, Bartlett B. Heard, urging the Portland chapter to form a local committee to aid the relocation efforts of Japanese Americans to the Portland area, citing the lack of any local association focused on the issue. Heard cited the many YWCA efforts to aid relocation, such as the Student Relocation Council, which helped Japanese Americans find housing, employment, and good will in their new communities. In Heard's opinion, the Japanese Americans' return to Portland deserved the same support as Nisei relocating East of the exclusion zones. ${ }^{220}$ At a meeting on 12 December 1944 , the Portland YWCA Board of Directors decided it was time the Portland chapter declared publicly that it was ready to aid returning Japanese Americans. On 16 January 1945, the Board approved this statement:

The purpose of the YWCA has always been to serve women and girls without regard to race, color, or creed. Many young women and girls of Japanese descent were members of the Portland Association prior to their evacuation, and have continued their affiliation and YWCA activities in the relocation centers. We now affirm the historic attitude of the YWCA toward all persons, and stand ready again to be of service to persons of Japanese ancestry, and to receive them into our Association, whenever the government of our country, with its unique facilities for complete investigation of loyalty, permits their return to this area. ${ }^{221}$

Although the YWCA did not create a specific committee to aid returning Japanese Americans, they finally went on record as supporting them, an act the YWCA had largely refrained from in the internment era.

Local WRA officials Henry Fistere and Clyde W Linnville were much more focused in their efforts to aid Japanese Americans returning to Portland. The Portland

\footnotetext{
${ }^{220}$ Barttlet B. Heard, Letter to all YWCA Associations in the Western Defense Command, Personnel: Correspondence, Contracts, News Articles 1940-50, Box 7, Folder 28, Oregon YWCA Collection, Lewis and Clark College Special Collections.

${ }^{221}$ Minutes, Board of Directors YWCA 12 December 1944 and 16 January 1945, 9B-1, Oregon YWCA Collection.
} 
Citizen's Committee to Aid Relocation was first formed when WRA Northwest Area supervisor Henry Fistere spoke at a meeting in Portland. Fistere, Reed college professor Blair Stewart, and Lorene Rickert formed the group in the hopes of helping returning Japanese Americans find both housing and employment. ${ }^{222}$ Linville, as the Portland representative for the WRA, made it a point to respond to public acts of antiJapanese discrimination whenever they came to his attention.

A number of local lawyers also came to the aid of Japanese Americans through public statements and investigations. Gus Solomon, the Portland representative of the ACLU had urged, although unsuccessfully, that the national organization to support the Minoru Yasui test case in 1942. He had also urged the Portland chapter of the American Jewish Congress to oppose internment in 1942, even though he ended up as the only Jewish leader to stand up for the issue. ${ }^{223}$ Thus when a reporter from the Oregonian called him for a comment in response to the lifting of exclusion orders, Solomon claimed: "I'm glad to see the exclusion order rescinded. We were thinking seriously of filing several suits along the coast to test the constitutionality of the order. I hope the Japanese are brought back gradually and established in communities where they will be well received." ${ }^{224}$ Supporting returning Japanese Americans was a way for Solomon to assuage his personal guilt at not supporting Japanese Americans previously. ${ }^{225}$

\footnotetext{
222 "Evacuess to be Aided by Rose City Group," Minidoka Irrigator, 17 February 1945, 2.

${ }^{223}$ Ellen Eisenberg, The First to Cry Down Injustice?: Western Jews and Japanese Removal During World War II, (Lexington Books: Lanham, MD: Lexington Books, 2008), 79.

224 "Oregonians Eye Issue Debatably," Oregonian, 18 December 1944, 1.

${ }^{225}$ Before the end of 1942, Solomon deeply regretted not standing up for Japanese Americans. As William toll and Ellen Eisenberg note elsewhere, the Jews of the West Coast succeeded partially because of "their allegiance to the white majority." Despite the Nikkei's obvious need for allies, the
} 
This turned out to be a bold statement. In response to the article, Solomon received numerous angry phone calls, some of which threatened to blow up his house. His statement also gained the attention of Betty Sale of the National Conference of Christians and Jews, who had been working with the Portland Council of Churches at the YWCA. She also called Solomon to ask him to start attending meetings planning aid to Japanese Americans. ${ }^{226}$ Solomon soon became a key figure in the group, speaking in churches about the desirability of the return of Japanese Americans, and helping returning Japanese Americans regain their land in Gresham and Hood River.

\section{Exclusionists Face Increasing Pressure}

Anti-Japanese organizing in Portland in the return era faced significant challenges. The Japanese Exclusion League had serious difficulty finding a meeting place in Portland due to the opposition of MacNaughton and church groups. ${ }^{227}$ Reverend Maulbestch of the Portland Council of Churches had signed a public resolution calling for the "constitutional treatment of Japanese Americans." He received a storm of angry phone calls, confirming the presence of a number of Portlanders who believed Japanese Americans did not deserve constitutional rights guaranteed by the Fourteenth Amendment, but Portland leaders willing to publicly condemn Rev. Maulbestch were in short supply. ${ }^{228}$ Other than random editorials, arguments for tolerance towards Japanese Americans went uncontested in the press.

Portland Jewish community was not willing to appear unpatriotic by siding with them. Solomon thought Jews and Japanese Americans faced a similar threat, and that the European example showed that Jews could be the next group shipped off to camps. Stein, p. 76, 78.

${ }^{226}$ Oral History with Gus J. Solomon, transcript, Oregon Jewish Museum Archives, 13.

${ }^{227}$ Letter to Clifford G. Schneider from Walter Pierce, 16 January 1945, Pierce Collection, 68-16-8.

228 “Portland Minister Threatened for Favoring Japanese," Minidoka Irrigator, 9 December 1944, 2. 
Faced with a lack of support in Portland and open opposition from church groups, and an Oregon Anti-Japanese Inc. more interested in defending local claims to property rather than the statewide campaign he had in mind, American Legion attorney Thomas Mahoney withdrew from anti-Japanese organizing. He claimed his Portland group was opposed to racial discrimination and had no "sympathy with the movement. ${ }^{, 229} \mathrm{He}$ also later refused to sponsor a second series of anti-Japanese memorials in $1945 .^{230}$

Correspondence between Pierce and other anti-return organizers shows their increasing marginalization. Richard G. Scott, an organizer for the Japanese Exclusion League (JEL), lamented the silence that followed his letters to Oregon state representatives. I "have had no reply yet [to requests for anti-Japanese legislation in the Oregon statehouse]," Scott observed, "perhaps he has been struck with the same disease of silence that hit Morton Tompkins [head of the Oregon State Grange] and the Legion heads, and Tom Mahoney." Scott especially blamed "easy to dupe" church groups and their "big mission interests in Japan" for the anti-Japanese movement's inability to get a fair airing of grievances in the press. ${ }^{231}$ Later, in writing the California Council on Alien Relations, Pierce told the group Mahoney reversed his opposition to the Japanese and that he was having a hard time finding a state

\footnotetext{
229 "Papers Recalled for 'Race' Group,” Oregonian, 11 January 1945, 7.

${ }^{230}$ Another Portland representative to the Oregon Legislature, Warren Erwin, took his place, introducing

House Joint Memorial 8, calling for a continuance of Japanese incarceration until the end of the Pacific War. Representative Vernon Bull, from Pierce's home district in La Grande, introduced House Joint Memorial 7, which called for the deportation of Japanese Americans with dual citizenship. Oregon House and Senate Journal, 1945, 442.

${ }^{231}$ Letter from Richard G. Scott to Walter Pierce, 4 February 1945, Pierce Papers, 68-16-8.
} 
representative "who would brave the displeasure of the Portland papers by fathering" an anti-Japanese resolution. ${ }^{232}$

C. G. Schneider, attorney for the JEL, wrote Pierce looking for an explanation for Mahoney's change of heart as well as to set up a public JEL meeting in Portland. ${ }^{233}$ Pierce had no explanation about Mahoney, adding that a meeting in Portland was probably out of the question. He claimed to have received a number of "invitations to speak on the Japanese issue," but since November 1943 all had been canceled due to the efforts of business leaders in Portland interested in cheap labor and church groups interested in converts. ${ }^{234}$ Public organization in Portland would be futile because of opposition from the press, church groups, and business leaders like E. B. MacNaughton. By early 1945 in Portland at least, the movement to oppose the return of Japanese Americans lost all possibility of receiving favorable press.

Seeking support outside of Portland, Pierce and JEL officials sponsored a series of public meetings to collect funds for their organization. They held their first public meeting 8 February 1945 in Gresham. The meeting featured Edington of the American Legion, Pierce, and Schneider of the Gresham-based JEL. The speakers continued calls for deportation of all Japanese after the war due to a race-based loyalty to Japan and enforcement of the 1923 Alien Land Law. More than one thousand people from all over Multnomah County, including a large delegation from Portland,

\footnotetext{
${ }^{232}$ Letter to the American League, Council on Alien Relations from Walter Pierce, 26 February 1945, Pierce Papers, 68-16-8.

${ }^{233}$ Letter to Walter Pierce from C. G. Schneider, 16 January 1945, Pierce Papers 68-16-8.

${ }^{234}$ Letter to C. G. Schneider from Walter Pierce, 19 January 1945, Pierce Papers 68-16-8.
} 
attended. Scott asked attendees to join JEL, paying \$10 in initial membership and one dollar per month after. ${ }^{235}$

Most consequentially, Pierce demanded that Governor Snell and the state legislature take action on the issue of evasion of the Alien Land Law. ${ }^{236}$ On 26 February, the same groups brought their argument to legislative hearings, at which only one representative questioned calls for Japanese deportation. ${ }^{237}$ The very next day, Snell introduced an update to the 1923 Oregon Alien Land Law designed to bring it in line with similar measures in California. ${ }^{238}$ Perhaps in memory of the political power of the 1920s Oregon Klan, all state senators and all but two state representatives supported the bill for fear of a political backlash. ${ }^{239}$

The same day the Oregon Alien Land Law of 1945 passed the legislature, Sprague, MacNaughton, Harold Fistere of the WRA, and Norman Coleman of the Portland Citizen's committee spoke to a crowd of five-to-six hundred in Gresham to counteract the growing power of the JEL in rural parts of Multnomah county. Sprague and Fistere both argued that the return of Japanese Americans was completely up to the U.S. Army, and it was their duty to comply. Coleman went further, arguing against

\footnotetext{
${ }^{235}$ Beatrice Stevens, Free and Equal? The Japanese Americans in Oregon, Portland, Oregon, 1945, p. 14.

236 "Pierce Slaps at Japanese: Ex-Governor Says Race Doesn't Fit," 10 February 1945, p. 4.

${ }^{237}$ These hearings regarded Joint house memorial no. 9, which was introduced by Portland representative Warren Erwin and aimed to deport all Japanese Americans with Japanese citizenship. Strangely, Portland church and civic leaders were absent from the hearings. See, "Farmers Ask Japanese Ban," Oregonian, 27 February 1945, p. 9.

${ }^{238}$ Earl Snell, Statement to Legislature, undated, Box 2, Folder 4, Snell Papers, Oregon State Archives. ${ }^{239}$ Oregon House and Senate Journal, 1945, p. 483. The bill was introduced 27 February 1945, then passed quickly after being released from committee on 16 March 1945. Oregon legislators seemed to be heeding an article in the Oregon Voter, which claimed that opponents of returning Japanese Americans were "implacable," assuming the heated rhetoric of the JEL and Hood River American Legion represented a widely held belief among Oregon farmers. See "Anti-Japanese Question in Legislature," Oregon Voter, 16 December 1944, pp. 5-10.
} 
the charge that Japanese labor depressed wages, but MacNaughton truly captured the idealism of the growing civic nationalism in Oregon. He said:

We are at a crossroads...the great evil of the war is not physical but spiritual; not the ruin of cities and killing of bodies but the perversion of all that is best in men's spirit to serve the purposes of destruction, hate, cruelty, avarice, deceit, and revenge...In the confused and dreadfully anxious postwar days ahead of us our state and nation may face other appeals to prejudice. We know that happened in Europe. That can happen here. ${ }^{240}$

MacNaughton's comparison of anti-Japanese activism to fascism represents an important shift in public discourse on racial issues. Whereas the Oregon Voter viewed anti-Japanese racism as a valid viewpoint, MacNaughton made a deliberate comparison between Nazi ideology and the exclusion of Japanese Americans. ${ }^{241}$ Given the racial basis for many of Schneider and Pierce's arguments, such a portrayal was impossible to counter in the press. Subsequently, the JEL quickly lost support in rural areas, despite the fact that Japanese exclusion aided many farmers seeking to hold on to Japanese land leased to them by the Farm Security Administration during internment. $^{242}$

Over the course of the Spring, the Citizen's Committee gained ground in these public meetings, JEL audiences dwindled, and pro-Japanese groups became more bolder in their calls for tolerance. For instance, when students at Sherwood High School discovered that their auditorium was to be used for a JEL meeting, they

\footnotetext{
${ }^{240}$ Multnomah County is the county in which Portland is located. "Expulsion of Japanese Topic of Oregon Paper" Minidoka Irrigator, 24 March 1945, p. 1.

241 "Anti-Japanese Question in Legislature," p. 9.

${ }^{242}$ Portland businessmen were not the only ones to profit from Japanese incarceration. Many farmers obtained leases through the Farm Security Administration in 1942, and supported Japanese exclusion in the hopes of keeping that land. This desire was particularly strengthened by the doubling of farm income over the course of the war and ten-fold increase in farmland prices. Buck, p. 65.
} 
distributed cards disputing JEL claims and denounced speakers' remarks during the meeting. ${ }^{243}$ In June 1945, the Portland Citizen's Committee also used local connections to block a boycott of Japanese American grown produce. ${ }^{244}$

Accounts of gains by the Portland Citizen's committee filtered into Minidoka by way of the Minidoka Irrigator. Editorials in the Irrigator portrayed MacNaughton and Fistere's efforts as similar to the efforts of white soldiers working with Nisei soldiers on the battlefields in Europe. Nisei editors used the Portland Citizen's Committee meetings to spur returning Nisei to erase the public space between their Japanese and American identities. They claimed that, in the "fight for America's principles, we owe it to them [Caucasian allies] to show by our attitude that we are standing with them in the front lines." The alternative was to show bitterness about the loss caused by incarceration, which would undermine solidarity with whites. ${ }^{245}$

Hachiya, an early returnee businessman, embraced connections to the military because those connections were key to the pro-Japanese argument in Oregon at the time. Portland in 1945 had experienced a dramatic shift towards civic nationalism. Japanese Americans interested in carving out a space for the Nikkei community had discovered that an embrace of the U.S. Army as a force fighting for freedom and democracy fostered public acceptance. The connection allowed both Japanese Americans and white Americans in Portland to embrace civic nationalism together.

\footnotetext{
${ }^{243}$ Stevens, p. 38.

${ }^{244}$ Pursinger, P. 405.

245 “An Appeal to Courage,” Minidoka Irrigator, 24 March 1945, p. 4. The term bitterness here is a key term often used in WRA camp newspaper as a euphemism for draft resisters, No-No boys, repatriates, and alternative Nisei civil rights groups. Essentially, this rhetoric allowed the JACL and WRA authorities to monopolize the public connection between civic nationalist groups and the Japanese American community.
} 
This vision of Nikkei-Caucasian solidarity had little to do with the realities that returning Japanese Americans faced, but was nonetheless a powerful argument for Nikkei acceptance in postwar Portland. 
Chapter 4: Experiments in Acceptance

Focusing on the resettlement period allows the historian to step from behind the traumatic veil of internment. It allows a focus not on the abusive agency of Federal authorities in curtailing civil rights but also on Nikkei strategies of gaining acceptance, both through court cases against discriminatory laws and through alliances with the white community. The fact that many Japanese Americans proclaimed their loyalty based on an image of the patriotic service of the $442^{\text {nd }}$ Combat Team of the US Army must not be allowed to overwhelm all other narratives of acceptance. One must be careful when investigating this period not to simplify campaigns to aid the Japanese American community only within the context of civil rights. For a majority of Portland's Japanese Americans, economic concerns took precedence over the more lofty goals of gaining the full rights, privileges, and duties of American citizenship.

The situation in Portland was unique compared to other West Coast Japanese American communities in that key Issei continued community leadership roles after internment. The Issei, who constituted the majority of returnees to Portland in early 1946 (there were 463 Issei and 396 Nisei), ${ }^{246}$ played a key role in overturning legal statutes that challenged their ability to seek a livelihood in Portland. Portland Issei leaders, working with Nisei associates, initiated a test case of the Oregon Alien Land

\footnotetext{
${ }^{246}$ War Relocation Authority, Relocation Program, (Washington D. C., 1946), 104. Also found in: Eiichiro Azuma, “A History of Oregon's Issei, 1880-1952," Oregon Historical Quarterly, Winter 19931994, 356.
} 
Law in 1946, finding significant support in the larger community through a very successful funding raising drive.

During 1946, associated members of the national organization also reorganized the Portland chapter of the Japanese American Citizens League (JACL). Although the Portland chapter was fairly active between 1946-1948, leadership constantly complained of a lack of participation in their activities and a lack of interest in the JACL's civil rights program. Furthermore, fund raising activities by the Portland chapter were often much less successful than Issei ventures. The correspondence between National JACL leaders reveals conflicts over finances and directives that sought to subordinate local efforts to the cause of a national civil rights campaign. The archives of the Portland Chapter JACL and the Oregon Nikkei Legacy Center Archives tell the story of this fledgling chapter and bring to light the choices made by Japanese Americans in the face of continuing economic discrimination.

\section{White Progressives Shift Focus}

In 1946, proponents of civil rights for the Nikkei were ready to declare victory. The same press that had decried the injustice of internment began to describe the decline of public anti-Japanese bigotry as a victory of the spirit of "true Americanism" over intolerance. Writing for the Associated Press, journalist Ann Reed Burns used the state of Caucasian-Nikkei public relations as a barometer of tolerance in Oregon as a whole. She pointed to the restoration of Nisei soldier names to the American Legion's 
public honor role, the disappearance of "no Jap trade" signs, and the lack of violent incidents as proof of the transient nature of anti-Japanese sentiment in Oregon. ${ }^{247}$

In the Saturday Evening Post, William L. Worden attributed former antiJapanese organizations as the product of a few agitators, now sullen in their failure to prevent the return of Japanese Americans to the West Coast. He described them as "unrepentant, and still disgruntled about tactics of the WRA, but...prepared to get along with their Japanese neighbors." ${ }^{248}$ Leading figures of the anti-Japanese movement in Oregon were certainly unapologetic. For instance, until his death in 1954, former governor Walter M. Pierce remained avidly anti-Japanese because of his belief in Anglo-Saxon supremacy. ${ }^{249}$ Like the Oregon Ku Klux Klan of the 1920s, the Japanese Exclusion League was reviled by the press and then forgotten.

Between January 1945 until the summer of 1946, Portland religious leaders, the Citizen's Committee to Aid Relocation, and officials from the War Relocation Authority (WRA), spearheaded relief efforts in employment, housing, and public image issues. The shuttering of the concentration camps in late 1945 led to the winding down of aid work conducted by the War Relocation Authority (WRA). Northwest officials of the WRA, especially Northwest Area director Harold S. Fistere and Oregon relocation officer Clyde W. Linville, worked closely with the Portland Citizen's Committee to Aid Relocation to help relocatees find work and shelter in Portland. The Northwest section of the WRA worked with other federal agencies to

\footnotetext{
${ }^{247}$ Ann Reed Burns, “Japanese Coast Return 'Better Than Expected'," Oregonian, 10 February 1946, p. 14.

${ }^{248}$ William L. Worden, “The Hate That Failed," Saturday Evening Post, 4 May 1946.

249 Arthur H. Bone, Oregon Cattleman/Governor: Memoirs and Times of Walter Marcus Pierce, (Portland, OR: OHS Press, 1981), p. 410.
} 
aid Japanese Americans. In June 1945, the Federal Housing Authority opened federal public housing to Japanese Americans in Portland, Seattle, and several other cities to meet a sever housing shortage. ${ }^{250}$ Furthermore, during the height of the public return debate in early 1945, these WRA officials countered each public anti-Japanese meeting with one urging equal treatment of all citizens. Although Fistere and Linville tried their best to remain out of the public eye, they were passionate advocates for returning Japanese Americans. They were especially helpful in overcoming antiJapanese boycotts in Portland and Hood River. ${ }^{251}$

Linville and Fistere also published a number of pamphlets to aid Japanese Americans returning to the Northwest. ${ }^{252}$ One of these guides took the form of an extended letter to relocatees, in which Linville detailed the various Federal agencies, lawyers, and community organizations available to them. He also expressed confidence that "the situation in Oregon is well in hand and that your various needs are being and will continue to be met." The Portland WRA office was slated to close on 31 May $1946 .^{253}$

Days before the office closed, a group of 200 Issei and Nise, i led by Issei community leader Daiichi Takeoka and Nisei veterans Bill Oda and Charles Shimomura, held a testimonial dinner to thank the WRA, the Portland Citizens Committee to Aid Relocation, and local church groups. At the dinner, Linville

\footnotetext{
${ }^{250}$ Harold S. Fistere, “Analysis of the Final Report,” Northwest Area, WRA, 2 May 1946, Microfilm 9, Reel 2, Oregon Historical Society Research Library.

251 "Relocation Authorities Amazed By Splendid Reception Given Evacuees Returning to Oregon," Pacific Citizen, 16 February 1946, p. 2.

${ }^{252}$ For instance: "Resettlement Bulletin: Northwest Area," Coll 15, 2009.15, Oregon Nikkei Legacy Archives.

${ }^{253}$ Clyde W. Linville, “To all Relocatees,” 31 January 1946, PDX Collection, cover page.
} 
described the continuing racial problems the Nikkei would face in the postwar era. Locally, the Portland City Council's continuing ban on municipal business licenses for Issei posed a bar to reestablishing businesses lost in 1942. Also, Issei were still barred from land ownership in Washington, California, and Oregon. Linville challenged the Issei to overturn the laws, hoping "someone will find occasion to make a real test of them.” Irvin Lechliter, the Seattle Regional Attorney for the WRA, went further, claiming, "[I] would like to see alien land laws in the three western states knocked out entirely" and "the group of aliens in the United States who are progenitors of the $442^{\text {nd }}$ Combat Team certainly are entitled to citizenship." ${ }^{254}$ Thus, this dinner represents a passing of the torch in the effort to secure rights of the Issei to the Oregon Nikkei community with the long-term goal of full citizenship.

White liberals in Portland still had plenty of work to do in the name of racial justice. Speaking to a reporter in 1946, Fannie K. Friedman of the WRA stressed, "as a result of exclusion, many persons of goodwill have become interested for the first time, in racial problems and in helping minority groups." ${ }^{, 255}$ The "White Trade Only" signs prevalent in downtown business windows of the time affected more than just Japanese Americans. The growing African American population in Portland faced many of the same barriers to social and economic equality. The Portland populations of Japanese Americans and African Americans had been roughly similar in the prewar period, roughly 2000 individuals each. ${ }^{256}$ The Japanese population diminished by thirty percent while the African American population grew to approximately 20,000 due to

254 “Nisei Praise WRA Activity: Aid in Evacution Days Recalled," Oregonian, 27 April 1946, p. 7. ${ }^{255}$ Burns.

${ }^{256}$ Rudy Pearson, "A Menace to the Neighborhood: Housing and African Americans in Portland, 19411945," Oregon Historical Quarterly, Vol. 102, No. 2, (Summer 2001), p. 161. 
an influx of workers coming to the Kaiser Shipyards. ${ }^{257}$ Accordingly, civil rights advocacy in Portland shifted largely to African American issues. For instance, key members of the Portland Citizen's Committee to Aid Relocation, such as Lansing E, Kempton and George Thomas, both from the Portland Council of Church's Commission on Race Relations, helped organize a Race Relations Clinic on 20 September 1945 designed to discus problems faced by minorities in housing and employment. ${ }^{258}$ The workshops focused almost exclusively on challenges African American economic and political rights. ${ }^{259}$

The first Nikkei community leadership group to emerge was a joint Issei-Nisei group called the Community Affairs Committee (CAC). This group was an even mixture of pre-war Issei community leaders, such as Daiichi Takeoka, former president of the Japanese Ancestral Society, Iwao Oyama, owner of the Portland paper Oshu Nippo, Ted Hachiya, Nisei hotelier, and Kimi Tambara, former editor of the Minidoka Irrigator. The CAC held regular meetings at the Nichiren Buddhist Church and served as the sole community organization available to help Issei unable to speak English. This group was also the only all-Japanese American group Linville recommended as a source of aid to Japanese Americans returning to the Portland area. ${ }^{260}$ The Nisei on the committee were largely new to community leadership. They

\footnotetext{
${ }^{257}$ The Urban League of Portland, "Second Annual Report-1946," Organizations: Other Womens Organizations, Pamphlets, Brochures, Newsletters, 1940s+, Box 7, Folder 16, Papers of the Young Women's Christian Association, 1901-2001, Lewis and Clark College Special Collections and Archives. 258 "Race Relations Clinic," Box 3, Folder 3, Snell Papers, Oregon State Archives.

${ }^{259}$ Letter to Earl Snell from Elda Russell, Oregon Protective Society, 24 September 1945, Snell papers $3: 3$.

${ }^{260}$ Clyde W. Linville, “To all Relocatees,” 31 January 1946, PDX JACL Collection, p. 1.
} 
assumed the place of previous JACL leaders such as Hito Okada and Minoru Yasui who moved on to National JACL leadership during the internment period.

The CAC provided general aid to returnees, but also sought to eliminate local anti-Japanese statutes that continued to bar their participation in the Oregon economy. Takeoka recognized that the Issei faced significant hurdles to reestablishment in Oregon. The WRA had been unable to address issues such as the Portland City Council's ban on municipal business licenses for Issei and the Oregon Alien Land Law. $^{261}$

Takeoka had long sought to repeal the Oregon Alien Land Law. When the law first appeared in the Oregon Legislature, passing in 1923, he hired white lawyers from Portland to lobby the Oregon Legislature on behalf of the Japanese Association. ${ }^{262}$ Takeoka, a graduate of the University of Oregon Law School in 1912, was well respected in Portland's white legal community. However, he was not admitted to the Oregon Bar because he could not obtain United States citizenship. Because he could not practice law in Oregon, he, like many other educated Issei in Portland, went into business working with Japanese American farmers as a fertilizer salesman. ${ }^{263}$ Through these duties and through his capacity as a member of the Japanese Association, he served as a legal advisor for much of the Oregon Nikkei community. Thus, shortly after the act became law, Takeoka helped Issei all over the state evade the law by

\footnotetext{
${ }^{261}$ Azuma, 356.

${ }^{262}$ Kazuo Ito, Issei: A History of Japanese Immigrants in North America, Trans. Shinichiro Nakamura and Jean S. Gerard, (Japan: Japan Publishing, 1973), pp. 161-162.

${ }^{263}$ Ted W. Cox, The Toledo Incident of 1925: Three Days That Made History in Toledo, Oregon, (Old World Publications: Corvallis, Oregon, 2005) pp. 144-145.
} 
placing land titles in the names of their children. ${ }^{264} \mathrm{Up}$ until the beginning of World War II, he served as the chief Issei advocate for the legal avenues of redress to statutes targeting Japanese Americans in Oregon.

Many historians have noted how Issei community leaders ceded authority to the Nisei during internment. Paul Spickard has written that Issei heads of families in WRA camps saw their role as providers and decision makers undermined. This facilitated a shift in community leadership to the Nisei, through the JACL and other groups, during and after incarceration. ${ }^{265}$ Azuma, however, amends Spickard's general argument, claiming that the legal challenge to the Oregon Alien Land Law was largely an Issei venture in which the Portland JACL played a support role. ${ }^{266}$ Azuma does not make clear, however, that the Portland JACL had yet to re-form in April 1946 when the project was initiated. The effort to overturn the Oregon Alien Land Law was an Issei-led venture, demonstrating a transwar continuity of Issei leadership in the Portland Nikkei community.

Given that Spickard's assessment was true of the West Coast Nikkei Community in general, Portland can be said to have had unusually active Issei. The reason may be the nature of their incarceration. Takeoka, Oyama, Masuo Yasui, and four other Issei were board members of the Japanese Association of Oregon, who received commendations from the Japanese Foreign ministry in 1940 at the $2600^{\text {th }}$

\footnotetext{
${ }^{264}$ Tom Takeoka, Letter to Rebecca Patchett, 9 Nov 2007, Daiichi Takeoka, Figure Files, Oregon Nikkei Legacy Center Research Library, p. 2.

${ }^{265}$ Paul Spickard, "The Nisei Assume Power: The Japanese American Citizen's League, 1941-1942," The Pacific Historical Review, Vol. 52, No. 2 (May 1983), p. 147.

${ }^{266}$ Azuma, 356.
} 
Anniversary Celebrations of the Japanese Empire. ${ }^{267}$ Awardees were named “civilian[s] of merit" and received an ornamental wooden cup for their personal achievements and services rendered to the Japanese government. Presumably, these awards were the reason these Issei were arrested and held by the FBI as dangerous alien enemies during World War II.

Unlike other Issei detained in this manner, cup recipients were generally not allowed to join their families in WRA camps. Oyama's son Albert speculated after reviewing his father's Department of Justice (DOJ) dossier that, because his father had received the wooden cup, he had been held in DOJ camp until as late as January 1946, even though he had been eligible for parole as early as November $1944 .{ }^{268}$ Unlike Issei who were moved to WRA camps, the Issei in DOJ camps did not abdicate leadership to the Nisei. When Takeoka returned to Portland in July $1945,{ }^{269}$ and Oyama returned in January 1946, they quickly resumed leadership roles in the Portland Nikkei community.

In April 1946, the CAC formed the Oregon Alien Land Law Test Case Committee. Chaired by Takeoka, the Test Case Committee initially focused on a fundraising campaign. ${ }^{270}$ According to Portland Nisei Ted Hachiya, who donated $\$ 500$ and led the drive, Issei and Nisei fund-raisers collected $\$ 17,000$ in three to four months

\footnotetext{
267 "Japanese Association of Oregon," Japanese Association of Oregon, Community Organization Files, Oregon Nikkei Legacy Center Research Library.

268 "Japanese Internees in Missoula from the Portland, OR Area," Japanese Association of Oregon, Community Organizations, Oregon Nikkei Legacy Center Research Library.

${ }^{269}$ Tom Takeoka, e-mail to Rebecca Patchett of Oregon Nikkei Legacy Center, Local Figure Files, Takeoka, Daiichi, Oregon Nikkei Legacy Center Research Library, p. 1.

${ }^{270}$ Azuma, 356-357.
} 
from Japanese Americans across Oregon to pay legal fees. ${ }^{271}$ The committee then secured representation by Verne Dusenbery, who had published a report refuting antiJapanese arguments and claiming the Alien Land Law violated the $14^{\text {th }}$ amendment the previous year. ${ }^{272}$ The committee's civil rights approach was a strategy depending on legal redress. Considered as a movement, this legal campaign was virtually an allNikkei endeavor with little participation by the white community.

The joint Issei-Nisei CAC represents a lost opportunity for the Portland Nikkei community. The split that characterized the prewar Portland Nikkei community could have been avoided in the postwar period. The CAC had the unique opportunity to reunite the Nikkei community; including former draft resisters, Issei targeted by the FBI in 1942 for connections to the Japanese Consulate, and fervent supporters of the Nisei veterans. Although the CAC was concerned about the place of Japanese Americans in Portland, economic rights took precedence over civil rights. They were chiefly concerned with clearing the legal hurdles facing Issei farmers and businessmen. Overcoming these barriers spoke to the entire Japanese American community. Subsequently, the CAC was able to raise significant funding to combat the Oregon Alien Land Law. Portland Nisei, however, had their own vision for the postwar Nikkei community.

\section{Echoes of Camp Life}

The closure of WRA offices in Portland coincided with the reorganization of the Portland chapter of the JACL. Nisei who were members of the national JACL

\footnotetext{
${ }^{271}$ Oral History with Ted Hachiya, transcript, Oregon Nikkei Legacy Center Research Library.

${ }^{272}$ Verne Dusenbery, “The Japanese Problem in Oregon,” Oregon Law Review, 24 (1944-1945), pp. 208-219.
} 
sought a connection to political debates affecting Japanese American rights at the federal level through the reformation of the Portland chapter. Mary Minamoto spearheaded this campaign, becoming a strong advocate in Portland for ideological orientation surrounding the National legislative campaign. According to a letter sent to all associated members in April 1946, the National JACL had two goals in improving Japanese American civil rights: "compensation for losses sustained by the evacuees" and the removal of the racial bar to naturalization that would nullify anti-Japanese laws that depended on the phrase "ineligible to citizenship." The letter also asked members to urge friends to join the JACL and to support the continuing struggle for civil rights by paying dues of $\$ 5.00$ per year. Reflecting common justifications by the JACL, the letter referenced the efforts of the $442^{\text {nd }}$. "We believe these dues are not unreasonable - especially in light of the work that lies ahead. Considered in terms of the sacrifices which our Nisei soldiers made, they are insignificant." ${ }^{273}$ Efforts to reorganize the Portland JACL chapter maintained the story of $442^{\text {nd }}$ sacrifices as its central theme.

The Portland Chapter of the JACL was reactivated officially on 11 May 1946 when Hito Okada, former Portlander and National President of the JACL, paid a visit to Portland's associated JACL members. ${ }^{274}$ At the meeting, it was decided that a movie about the $442^{\text {nd }}$ should be shown to commemorate Memorial Day. However, none was available, so Minamoto wrote National headquarters to request a record of a speech by Ben Kuroki, often referred to by the JACL as the first Nisei war hero, along

\footnotetext{
${ }^{273}$ Letter to Associated Members, from National JACL President Hito Okada, 8 April 1946, Letters to Mary Minamoto 1946-1947, JACL PDX Collection.

274 “Portland Chapter JACL Activities," 1946-1948, PDX Minutes, PDX JACL Collection, p. 1.
} 
with receipt books to record memberships. ${ }^{275}$ Minamoto's desire to play a speech by Kuroki reveals her commitment to a narrative of redemption for Nisei brought about by military service, even though this would have alienated some Portland returnees. Mass incarceration between 1942 and 1945 not only erased the physical and cultural center of the Japanese American community in Portland that had been Japantown, it also led to political debates in WRA camps that fractured the Nisei of Portland. At both Minidoka and Heart Mountain WRA camps, Nisei groups found themselves at odds with the JACL after organizing their own civil rights-oriented groups. As mentioned in the previous chapter, the Civil Liberties League (CLL) formed in Minidoka in December 1942 to financially support Minoru Yasui’s unsuccessful challenge to military curfew orders targeting Japanese Americans. The Seattle JACL members at Minidoka argued against Yasui's case contending, in the words of the National JACL spokesman Mike Masaoka, "that to help Yasui would be un-American." ${ }^{, 276}$ The leader of the Seattle JACL, Jimmie Sakamoto, publicly denounced the mostly Portlander CLL leading the group to disband though they continued to raise money for Yasui's legal fund. ${ }^{277}$

The national JACL responded to the emergence of the CLL and other civil rights-oriented Nisei organizations in 1943 by intensifying their own organization efforts. A month later, JACL members at Minidoka merged the Portland, Seattle, and Puyallup chapters, forming a Minidoka chapter of the JACL. The meeting was

\footnotetext{
${ }^{275}$ Mary Minamoto, letter to National JACL Headquarters, 12 May 1946, Correspondence of Mary Minamoto, PDX JACL Collection.

${ }^{276}$ Deborah K. Lim, "Research Report Prepared for Presidential Select Committee on JACL Resolution \#7," 1990, No-Nos, Subject Files, Oregon Nikkei Legacy Center Research Library, p. 47.

${ }^{277}$ Lim, 48.
} 
finalized the same day that Mike Masaoka and Hito Okada visited the camp to speak in favor of Nisei unity. ${ }^{278}$ Presumably, this allowed the national JACL to influence the aims of the reforming chapter along the lines of accommodation to the war effort. The resulting Minidoka chapter was an almost immediate failure, reflecting the low standing of the JACL among at Minidoka. After only three months, the chapter held its final meeting in order to liquidate its assets. ${ }^{279}$ Although no record exists of the reactions of Portland Nisei to the takeover, Portland Nisei were almost certainly alienated by high-handed JACL policies.

A somewhat similar situation arose at the Heart Mountain internment camp. At the end of January 1943, WRA camp newspapers announced plans by Secretary of War Henry Stimson to create an all Nisei combat unit made up of Hawaiians and WRA camp Nisei. ${ }^{280}$ This news was accompanied by talk of the need for a loyalty questionnaire as well as a draft including incarcerated Nisei. As historian Arthur Hansen discussed elsewhere, Frank Emi of the Heart Mountain Fair Play Committee opposed both on constitutional grounds. The group's printed materials claimed, “if democracy and freedom is to exist in this country, then we must uphold the ideals and principles of the constitution and right the wrongs committed to a minority group."281

The Nisei of Heart Mountain found Emi's argument persuasive. Of the 2000

\footnotetext{
278 “Masaoka Voices Plea for Unity,” Minidoka Irrigator, 27 January 1943, p. 1.

279 “JACL Meeting Slated Wednesday,” Minidoka Irrigator, 15 May 1943, p. 2.

280 “War Department Plans Completed,” Minidoka Irrigator, 29 January 1943, p. 1.

${ }^{281}$ Fair Play Committee Bulletin, "We Should Know," in Gail M. Nomura, et, al, eds. Frontiers of Asian American Studies, (Washington State UP, 1989), 50.
} 
volunteers for military service the Army expected from Heart Mountain, only 38 enlisted. $^{282}$

In a public meeting at Heart Mountain in March 1944, JACL leader Nobu Kawai condemned the movement, claiming, "Let us remember that the majority can change the constitution and make this a dictatorship if they so desire." ${ }^{283}$ The implicit argument was that draft resisters not only opposed the war effort, but risked provoking white Americans into even harsher treatment of Japanese Americans. The speech only served to encourage more Nisei to oppose the draft. ${ }^{284}$ Kawai then asked Ben Kuroki to make a speech in favor of volunteering for the Army. Perhaps because he was from Nebraska and had never been interned, Kuroki's appearance only served to make him the public face of what resisters considered government collaborators. ${ }^{285}$ Later, 800 Nisei became so demoralized by the affair that they renounced their American citizenship. $^{286}$

Again, the specific impact of these events on Portland returnees is unclear. Family members of renunciants would certainly have had mixed feelings about a continuation of wartime narratives of the $442^{\text {nd }}$ securing freedom for all Nisei in the postwar period. The Portland JACL papers hold little on the issue of draft resisters or renunciants, other than mentioning it as a topic of discussion among members of the

\footnotetext{
${ }^{282}$ Arthur A. Hansen, “ Protest-Resistance and the Heart Mountain Experience: The Revitalization of a Robust Nikkei Tradition," in Mike Macky ed., A Matter of Conscience: Essays on the World War II Heart Mountain Draft Resistance Movement, (Western History Publications: Powell, Wyoming, 2002), p. 98 .

${ }^{283}$ Frank Chin, Born in the USA: A Story of Japanese America, 1891-1947, (Rowman and Littlefield Publishers: Oxford, 2002), 415.

${ }^{284}$ Chin, p. 415.

${ }^{285}$ Chin, 435.

${ }^{286}$ Hansen, 98 .
} 
Portland Citizen's Committee to Aid Relocation in mid-1946. ${ }^{287}$ Unlike the JACL, the Citizen's Committee had no qualms about aiding Japanese Americans trying to reverse orders of deportation. The issue would have weighed on the mind of any Japanese American in the area because Portland was the departure point for all Japanese Americans that had renounced their citizenship.

Starting in December 1945, groups of repatriates, both Issei and Nisei, began their journeys to Japan. These ships would have been impossible to miss in the Portland harbor. At 609 feet long, they were the largest ships ever to dock there. ${ }^{288}$ For those standing at docks watching their loved ones sail away to war-torn Japan, the redemptive story of the $442^{\text {nd }}$ would have rung hollow. Although few accounts of attitudes towards the draft resisters exist, the JACL used the concept of embittered Japanese Americans as a means of identifying themselves as patriotic Americans.

\section{An All-Nisei Group Emerges}

The reformation of the Portland Chapter of the JACL largely followed the ideological orientation that helped Japanese Americans find allies within the white liberal community. It must be recognized that the continuation of the $442^{\text {nd }}$ argument was itself a choice; it was their chosen strategy of acceptance. The first meeting of the Portland JACL took place at the Nichiren Buddhist church following a service organized by the CAC to honor eleven of Oregon's Nisei soldiers killed in combat. ${ }^{289}$

\footnotetext{
${ }^{287}$ Mary Minamoto, Letter to Eiji Tanabe at JACL Headquarters, Salt Lake City, 7 June 1946, PDX JACL Collection.

${ }^{288}$ Lawrence Barber, “Japanese Due to Ship Home,” Oregonian, 26 December 1945, p. 12.

${ }^{289}$ Kimi Tambara, "Special Memorial Day Rites Honor Oregon Dead," The Oregon News, May 31, 1946, p. 1.
} 
This memorial fit quite well within the wartime, pro-Nisei narrative by emphasizing the valor of the all-Japanese American $442^{\text {nd }}$ Combat Team that was adopted by the white reporters seeking to discredit anti-Japanese agitators. These reporters used the stories of individual Nisei soldiers to shame West Coast racists, whom they saw as a challenge to the principles of freedom and democracy that legitimized the war effort.

Frank Hachiya, who was honored at the Portland memorial, was a key figure in putting forward this argument. His story was one of distilled patriotism. The New York Times said of Hachiya, "Japanese treachery reacted upon Hachiya as upon other patriotic Americans. To be sure his eyes were slanted, his skin was yellow, his name different. But Hachiya was an American. He enlisted at once. ${ }^{290}$ The article then went on to describe how Hachiya, who had been serving as an interpreter for a unit in the Philippines, volunteered to scout a Japanese position after a firefight to gather information. While doing so, Hachiya was shot by a Japanese sniper. Despite his wounds, he crawled back to his unit and died shortly after reporting to his commander. This article transposed the image of Hachiya's actions with the actions of the Hood River American Legion, who removed his name from a public honor role a month before he died. ${ }^{291}$ The implicit argument was that it was absurd to argue Japanese Americans held a racial loyalty to the Emperor. The Nisei patriotism argument hoped to underline the distinction between Japanese subjects and Japanese Americans with the argument that blood was no bar to patriotic service.

\footnotetext{
290 "Private Hachiya, American," New York Times, 17 February 1945, p. 12.

${ }^{291}$ Ibid. A similar and more extensive account of Hachiya's life and death appeared in the Oregonian in a series of articles about the place of Japanese Americans in Oregon: "Frank Hachiya: He was American at Birth—and at Death," Oregonian, 20 May 1945.
} 
The memorial service was an attempt by the Issei and Nisei of the CAC to bring the Nisei patriotism argument into the postwar period. The memorial emphasized the $442^{\text {nd }}$ unit's sacrifices during the rescue of the "Lost Battalion" in Italy in November 1944 and Frank Hachiya's death in the Philippines. Consecration of the Portland Nikkei community's contribution to the war effort represented an effort not only to establish a connection to an emerging postwar civic nationalism, but also to reiterate claims of loyalty based on service that had been key to undermining antiJapanese organizing in Portland during 1945. Following the WRA line that attributed the "6061 decorations" earned by the $442^{\text {nd }}$ as the main reason for improved attitudes towards Japanese Americans, Portland JACL members made commemorating Nisei combat efforts the key goal of their organization. ${ }^{292}$ This event also served as the first public post-internment meeting of the Portland chapter of the JACL. At the meeting, group of about thirty Nisei pledged interest in joining a new Portland JACL chapter if it were to be formed.

\section{Organizational Challenges}

The reestablishment of the Portland chapter of the JACL was a difficult process for local Nisei due to financial hurdles and the National JACL's lack of support. After returning to Portland in early 1945, Nisei hotelier Ted Hachiya attempted to reactivate the local chapter of the Japanese American Citizens League. ${ }^{293}$ This process was not complete until May $1946 .{ }^{294}$ The chapter's records do not explain the reason for this delay, but an important factor must have been lack of funds.

${ }^{292}$ Ann Reed Burns, “Japanese Coast Return 'Better Than Expected'," Oregonian, 10 February 1946, p. 14.

293 Portland JACL Minutes, 7 May 1947, PDX Collection.

${ }^{294}$ Untitled document, Portland Japanese American Citizens League Minutes, 1946, PDX Collection. 
Due to the rapid disbanding of the Portland JACL in the Spring of 1942 and the fact that leaders like Hito Okada had joined the national JACL leaders in Salt Lake City, their treasury and other assets had either been donated to the national JACL or had gone missing. ${ }^{295}$

The lack of sufficient funds was a constant concern for the Portland JACL early on, and led to conflict with the National JACL. At a meeting of the Portland Citizen's Committee in early June 1946, an upcoming Purple Heart Convention was mentioned. ${ }^{296}$ The convention was held in August with the purpose of "acquaint[ing] the public with what every racial group contributed to Victory.. ${ }^{297}$ Participation in this event, which demonstrated the Nisei contributions to the war effort, became the nascent chapter's first major project. In the words of Minamoto, "since we have had to face evacuation and many Caucasians are very concerned about our attitude of the experiences we had to face, I feel that it would be advisable to have a [Nisei] representative. ${ }^{, 298}$ So as not to be upstaged by other racial groups, the Portland chapter sought a Distinguished Service Cross holder among the Nisei community. Their search led them to George Sakato of Glendale, Arizona, who was to attend the convention on behalf of the JACL and speak at an associated testimonial dinner to

\footnotetext{
${ }^{295}$ Portland Nisei Mary Minamoto and Toshi Kuge wrote a number of letters in 1946 to former members of the Portland JACL looking for these assets. For instance, Mary Minamoto, letter to Mamoru Wakasugi, 23 June 1946, PDX JACL Collection.

${ }^{296}$ Mary Minamoto, Letter to Eiji Tanabe at JACL Headquarters, Salt Lake City, 7 June 1946, PDX JACL Collection.

${ }^{297}$ Toshi Kuge, letter to Hito Okada, 9 July 1946, PDX JACL Collection.

${ }^{298}$ Mary Minamoto, letter to Joe G. Masaoka and Minoru Yasui, 3 July 1946, Purple Hearts Convention, PDX JACL Collection.
} 
honor veterans and gold star mothers. The chapter estimated the costs at around $\$ 500 . .^{299}$

Coincidentally, former Portland JACL member Howard Nomura held a bond belonging to the chapter worth $\$ 500$. Unfortunately, the bond was not discovered until October. ${ }^{300}$ Attempts at canvassing the Nikkei community met with little success because Hachiya's fund drive for the Alien Land Law committee was still in full swing. ${ }^{301}$ Because the chapter believed that the convention was a national-effort to aid Japanese Americans, they sent out requests for funding to other chapters, and an ultimatum to national headquarters. In their letter to the national organization, the chapter asked the national organization for a loan of $\$ 500$ until local funds could be found. Above all, the Portland JACL sought to become more than the mere social club it was before World War II. If the loan was not forthcoming, they suggested they would "not accept JACL for our title.",302

Responses to these solicitations indicate the relationship between the Portland JACL and national leadership. Money was to flow up not down. Most chapters solicited by the Portland chapter declined with varying levels of annoyance, though some donated small amounts. ${ }^{303}$ Hito Okada, JACL national president, responded with an ultimatum of his own:

\footnotetext{
${ }^{299}$ Mary Minamoto, letter to Hito Okada, 24 July 1946, PDX JACL Collection. A Gold Star Mother was a common way to refer to mothers who lost sons to combat in the World War II era.

${ }^{300}$ Howard Nomura, letter to Hito Okada, 7 October 1946, Personal Correspondence of Mary Minamoto, PDX JACL Collection.

${ }^{301}$ Mary Minamoto, Letter to Bessie Watanabe, Mid-Columbia JACL, 31 July 1946, PDX JACL Collection.

${ }^{302}$ Author uncertain, but likely Kenzo Nakagawa, Portland Chapter President, letter to Hito Okada, 20 July 1946, PDX JACL Collection.

${ }^{303}$ The Snake River JACL sent \$25, while other chapters disagreed with Portland JACL's contention that the undertaking was a national affair. See Mack Kaneko, Denver JACL, letter to Kenzo Nakagawa,
} 
I personally believe that $\$ 500.00$ can be easily raised by the Japanese people in Portland. I am sure if the Issei are approached on this particular matter and they are advised of the tremendous Public Relations agenda for them, that they would be willing to raise this money for the project. I personally do not think that enough energy has been expended in Portland to raise the money...I further believe that if the reactivation of the Portland chapter depends upon whether or not National will loan them $\$ 500.00$ at this time, the National Headquarters too will have to further consider the matter of whether or not we wish to continue with the reactivation of the Portland chapter. In other words National Headquarters will not be intimidated into accepting the Portland Chapter. ${ }^{304}$

Okada's message was clear. If you wish to contribute to our cause we welcome you, but local issues are your own affair. He also sent a memo to all chapters prohibiting chapters from soliciting money from each other "in order that chapter treasuries shall not be raided constantly by requests for contributions." ${ }^{305}$ Furthermore, Okada designated the Issei as the proper source of funding for JACL causes. This assertion contradicts previous narratives that nearly all Issei were demoralized and destitute upon their return to the Pacific Coast. ${ }^{306}$ Some Issei must have still had considerable resources, which the success of the Alien Land Law Test Case Committee, a drive designed specifically to aid Issei, also attests to.

Okada's letter also helped catalyze the dissolution of the CAC. Following Okada's terse reply, the Portland Chapter apologized and redoubled their canvassing,

31 July 1946 and Mary Minamoto, letter to Joe Saito, Snake River JACL, 11 December 1946, PDX JACL Collection.

${ }^{304}$ Hito Okada, Letter to Mary Minamoto, 22 July 1946, PDX JACL Collection.

${ }^{305}$ National Headquarters, JACL, "Solicitation of Funds From Other Chapters," 1946, Budget, PDX JACL Collection.

${ }^{306}$ In Portland, there were significant exceptions to my assertion. Store owner and community leader Umata Matsushima saw his store seized the day of Pearl Harbor, his merchandise sold off at ten cents to the dollar, and he spent the rest of the war in a Department of Justice prison camp. Though he attempted to repatriate to Japan several times, he eventually returned to Portland. He had to borrow $\$ 500$ to restart his business, which he kept in the name of Harue Ninomiya until 1956 because he lived in constant paranoia that the government would confiscate it again. See Oral History with Yoji Matsushima, Interviewed by Valerie Otani, 2009, Oregon Nikkei Legacy Center Research Library. 
this time with the aid of Hachiya’s group. ${ }^{307}$ They eventually raised $\$ 837.50$ for events surrounding the Purple Hearts Convention. ${ }^{308}$ With the receipts for dinner tickets and other methods of fundraising, their campaign was a financial success because they turned to Issei donors. Speaking to a donor, Minamoto called the campaign a success, claiming, "many Caucasian friends were made at the convention." ${ }^{309}$ Her sentiments reflect the belief among Portland JACL leaders that making friends among the white community was a sure rout to improving their social standing.

In the months following the convention, the Portland JACL solidified this funding relationship. Hachiya, along with fellow CAC member Kimi Tambara, gained a seat on the JACL board as co-chair of the political action committee. ${ }^{310}$ In January 1947, the chapter convinced Issei leaders in Portland, presumably Oyama, Takeoka, and Yasui, to form a koenkai (mutual support association). Despite reservations of a "lack of cooperation" exhibited by the JACL to the Japan Society in the prewar period, the Issei agreed that the two generations needed to work together. Subsequently the Issei of the CAC agreed to provide funds for a full-time secretary and office for the Portland JACL. ${ }^{311}$ By March 1947 , Hachiya reported that $\$ 1566.50$ had been raised by the Issei who by 1952 came to refer to themselves as the Nikkeijinkai (Japanese Ancestral Society). ${ }^{312}$

\footnotetext{
${ }^{307}$ Mary Minamoto, Letter to Hito Okada, 24 July 1946, Personal Correspondence of Mary Minamoto, PDX JACL Collection.

${ }^{308}$ Milton Maeda,"Financial Statement: Purple Heart Convention and Testimonial Banquet,"11 September 1946, PDX JACL Collection.

${ }^{309}$ Mary Minamoto, Letter to Joe Saito, Snake River JACL, 11 December 1946, PDX JACL Collection.

310 "Committeemen of the local JACL," PDX JACL Collection.

${ }^{311}$ Milton Maeda, Letter to Hito Okada, 28 January 1947, Correspondence of the Treasurer, PDX JACL Collection.

312 "Minutes of the JACL Board," 15 March 1947, PDX JACL Collection.
} 
Had the JACL at the time accepted Issei members, and had there not been such a language barrier between the Issei and Nisei, the political leadership of the Portland Nikkei community might have coalesced in the Portland JACL. Instead, the two groups, along with other myriad social and religious groups, became a coalition of leaders similar to what existed at the Portland Council of Churches. Rather than being separated by denomination, the Nikkei were divided by generation, among other factors.

The coalition of community leadership of Portland Nikkei and their relationship to the National JACL guided a very specific strategy of acceptance. Because the majority of funding came from Portland-area Issei, the Portland chapter had to tend issues important to the Issei such as the continuing ban in Portland on business licenses and ongoing instances of discrimination. To ensure continued funding, they would also need to match their previous advocacy for the $442^{\text {nd }}$ as the chief narrative of acceptance while also focusing on economic concerns that made the Alien Land Law fundraising campaign so successful. They would also have to find a way to participate in National's legislative campaign to gain naturalization. All of this would have to be done within the strict parameters of National JACL leadership's directives. As war-era experiences with rival Nisei groups and postwar conflicts over funding attest, the National JACL had a specific vision for the way Japanese Americans would establish themselves as full-fledged members of American society. They would tolerate no rivals. 
Chapter 5: Successes, Failures, and Regular Minority Status

For Japanese Americans, returning to Portland following internment meant integration into an environment of continuing discrimination. Unlike the more confrontational tactics of sit ins and public protests employed during the civil rights era, leaders of the Portland JACL almost always worked with white progressives as well as with the national JACL when trying to improve their social and economic standing. By working with "Caucasian advisory boards," the Portland JACL sought the influence and support of Oregon's elected officials. Such boards gave a white face to the cause of Japanese American civil rights. Through their support and through legal cases, the Nikkei community overcame codified discrimination at the local and state level only to face discrimination of a more shadowy variety in the form of employment, housing, and other forms of prejudice that targeted non-whites.

The choice by Portland's Nisei leaders to work with the national JACL had its advantages and disadvantages. Association with the national JACL provided Portland Nisei with a chance to participate in the national campaign for Issei citizenship, efforts to aid Issei mostly met with apathy from Portland Nisei, and Issei were largely uninterested in JACL events. ${ }^{313}$ Furthermore, the national organization was generally

\footnotetext{
${ }^{313}$ A problem arises here due to a dearth of sources as to who the Japanese American community in postwar Portland was. Because the various Nisei groups organized a council of community group heads called the Presidents Council in the lates 1930s, community leadership is easy to ascertain. It is perilous however to assume that the same groups always existed in the postwar. Certain groups attached to institutions unaffected by internment continued in the postwar. For instance, the Japanese Girls Reserve (a YWCA youth program for Nisei girls) and a group of former Girl Reserves members calling themselves the Girls Cultural Guild (calling themselves the Veleda Club in the postwar) reconstituted
} 
unsupportive of local social justice efforts unless they were first coordinated with national headquarters. The result was a chronic lack of participation. The Nisei of Portland did not help lead a mass movement for civil rights. Instead JACL efforts in Portland were confined to relatively few people, so few that these individuals often became burned out by the demands of their positions within the JACL. Conversely, the Portland Nikkei community could be quick to respond to local crises as shown by a well-organized relief effort to aid the 900 Nikkei made homeless by the flooding of the Vanport housing project in 1948.

\section{More Opposition by the Portland City Council}

The largest hurdle facing Portland's Japanese Americans at the local level was the Portland City Council's 1942ban on municipal business licenses for Issei. After Portland license inspector Joe Hutchinson informed the City Council that nearly 200 Issei held licenses with the city, the council voted to cancel those licenses based on the belief that Issei property would be sold off at a dramatic discount during or after internment. In the following weeks Mike Masaoka and a number of attorneys representing Issei businessmen argued that such bans deprived Nisei children of sustenance and violated Issei human rights. ${ }^{314}$

Despite Masaoka's protest of the license ban before the Nikkei incarceration, the national JACL urged Portland JACL leader Abe Oyamada to avoid picking a fight

\footnotetext{
themselves after internment. Otherwise, community organizations consisted of groups related to the Nitiren Buddhist Church and Oregon Buddhist Church, Epworth United Methodist Church (formerly called the Japanese Methodist Church), a variety of sports organizations, and of course the morepolitical JACL, Nisei Veterans Committee, and the largely Issei Japanese Ancestral Society. See Deena Kei Nakata, The Gift: The Oregon Nikkei Story...Retold, (Oregon: D.K. Nakata, 1995), p. 142. Portland JACL, "Clubs," 1940-1941, Clubs File, PDX JACL Collection.

${ }^{314}$ Minutes of the Portland City Council, 29 January 1942, Portland City Archives.
} 
with the Portland City Council. The Portland Council of Churches' Race Relations

Commission, sought to press the issue using the Nisei Patriotism argument. ${ }^{315}$ In late May, the commission sent representatives to petition Portland's City Council to rescind the Issei license ban, but they were denied a chance to plead their case. In response, the commission invited Abe Oyamada, board member of the Portland JACL, to a committee meeting to gain more information. Specifically, the commission wanted to know if it was true that the Minidoka incarceration camp had garnered the most military volunteers. Their plan was to provoke a public confrontation with the City Council over the license ban, which they thought unfairly targeted both Japanese nationals and "refugee Jewish emigrants" fleeing the holocaust ${ }^{316}$ The Race Relations Commission seemed interested in recreating the Citizen's Committee meetings held in rural areas the year before, which effectively used the Nisei Patriotism argument to counter the Japanese Exclusion League calls for permanent exclusion.

After consulting with Oyamada and Ted Hachiya of the Portland JACL, the Race Relations Commission decided to forgo their planned confrontational approach, concurring with the national JACL's assessment. Hito Okada wrote to Oyamada on the issue confirming that Minidoka had indeed had the highest number of Army volunteers. He also recommended a hands-off approach that would avoid negative

\footnotetext{
${ }^{315}$ This work represented an extension of earlier efforts to protect the rights of Nisei businessmen. George Rundquist, the executive secretary of the Federal Council of Churches, after he visited Portland in July 1945, joined local WRA officials in condemning the Portland City Council for their requirement that Nisei be fingerprinted before being issued a business license. "Officials Rap City On Nisei Policy," Oregonian, 21 July 1945, p. 4.

${ }^{316}$ Abe Oyamada, Letter to National Headquarters, JACL, 3 June 1946, Issei Business License, PDX JACL Collection.
} 
publicity for city commissioners in the months before the 1946 elections. ${ }^{317}$ The Race Relations Commission came to the same conclusion when they realized that pushing the City Council on the issue would likely result in a court case.

Despite widespread support for the campaign to overturn the Alien Land Law, Issei volunteers willing to press the issue in court were not forthcoming. At a meeting of the Citizen's Committee attended by George Thomas of the Race Relations Commission and members of the Japanese American community, Elizabeth Dusenberry, Portland YWCA board member, gave a presentation on the state of Japanese businesses in Portland. Following the presentation, Thomas asked Hachiya and the other Nisei present if any Issei would be willing to press the issue in court. Hachiya said he doubted it. Thereafter, the whole license ban issue was left to United States Department of Justice, which had been in contact with Dusenberry and had implied that they were ready to act on the matter. So the commission let the matter drop in the hopes that the City Council would secretly kill the license ban. ${ }^{318}$

Decisive action was apparently not immediately forthcoming from the Department of Justice. The Portland City Council did not reverse their position until January 1947. Special conditions within the City Council motion to grant Issei business licenses again reflect continuing animosity towards Japanese immigration. The City Council voted unanimously to rescind the ban, but only for aliens ineligible for citizenship that had been residents of the United States for ten years or more. ${ }^{319}$ Uncertain whether Japanese immigration would continue in the postwar, the Portland

\footnotetext{
${ }^{317}$ Hito Okada, Letter to Abe Oyamada, 8 June 1946, Issei Business License, PDX JACL Collection.

${ }^{318}$ George L. Thomas, Letter to Abe Oyamada, 12 June 1946, Issei Business License, PDX JACL Collection.

${ }^{319}$ Minutes of the Portland City Council, 9 January 1946 and 16 January 1946, Portland City Archives.
} 
City Council sought to placate the Department of Justice, while also retaining the right to prevent future unwanted Japanese competition in business. Japanese immigrants with less than ten years residence were required to appear before the City Council to receive a business license. ${ }^{320}$ Concurrent with the character of the ban removal, the City Council decision came with no public apology.

Afterwards, the Department of Justice contacted National JACL president Hito Okada to notify him that the City Council had "secretly or otherwise drafted another [anti-Japanese business ordinance]...which couched in high sounding words is much worse and more discriminatory than the resolutions they repealed."321 Although the new license ban never materialized, its rumored crafting is further evidence that striking the license ban was no act of contrition by the Portland City Council.

Many Portland Issei were understandably wary of the direction Portland officials would take in the future, so they did not rush to file new business licenses. According to 1947 Portland JACL president George Azumano, Issei were able to file new licenses, but only three applied for them in the first six weeks. ${ }^{322}$ Many evaded the municipal license system in much the same way Issei farmers had circumvented the Oregon Alien Land Law; they filed business licenses under the name of Nisei. For example, Umata Matsushima owned a thriving general store named Teikoku (Japanese for "Imperial") before the Pacific War. He lost everything in the days after the Pearl Harbor incident when Federal officials closed his store and forced him to sell off his

\footnotetext{
${ }^{320}$ Ibid.

${ }^{321}$ Hito Okada, Letter to Portland Chapter JACL, 15 January 1947, Correspondence of the President, PDX JACL Collection.

${ }^{322}$ George Azumano, Letter to Hito Okada, 11 March 1947, Issei Business License, PDX JACL Collection.
} 
entire inventory, which was much larger than normal in expectation of holiday sales, at pennies on the dollar. They then confiscated the money along with the contents of his bank accounts and he was whisked off to a Department of Justice prison camp for the majority of the war. ${ }^{323}$

Matsushima was so demoralized by the affair that he applied for repatriation to Japan beginning a series of reversals by Federal officials that left his family's fate in limbo until he returned to Portland in 1946. In August 1943, Matsushima and his family were scheduled for departure from Ellis Island, federal officials decided that he would not sail. He experienced a similar wait in December 1943 at the Army camp in Crystal City, Texas and again was not allowed to depart. His family's luggage, however, left without them, leaving the family with literally nothing but what they were wearing. He then decided to apply to reverse the repatriation request in December 1945, but was still scheduled to leave from the Portland along with renunciants from Tule Lake. ${ }^{324}$ After a hearing at Tule Lake in March 1946, Matsushima and his family were released. By June 1946, the Matushimas were living in the Vanport housing projects. Because his accounts were not returned to him until 1956, Matsushima borrowed $\$ 500$ dollars to restart his business, called Anzen

\footnotetext{
${ }^{323}$ Oral History with Yoji Matsushima, transcript, Interviewed by Valerie Otani, 2009, Oregon Nikkei Legacy Center Research Library, pp. 1-2.

${ }^{324}$ Within the WRA camp system Tule Lake was a "Segregation Center," meaning that Nikkei sent their refused to take an infamous loyalty questionnaire, answered the questionnaire in the negative on questions regarding loyalty to the Japanese Emperor and U.S. military service, or wanted to repatriate from Japan. For renunciants, Tule Lake was a midpoint in their journey from Department of Justice Camps and Japan, making Portland a logical departure point geographically for all renunciants. The overwhelming majority of renunciants came from the Tule Lake center in the first place, of 2,360 renunciants shipped to Justice Detention camps, only 125 were from camps other than Tule Lake. Tetsuden Kashima, Judgement Without Trial: Japanese American Imprisionment During World War II, (Seattle: University of Washington Press, 2003), p. 278. "Umata Matsushima," FBI Arrests, Subject Files, Oregon Nikkei Legacy Center Research Library.
} 
(Japanese for "safety"), which became perhaps the most important Japanese supermarket in Portland in the early postwar decades. When refounding his business, Matsushima placed the license under the name of a friend's daughter, Harue Ninomiya. Family members later related that he was paranoid that the government would someday return to take his store and thus likely harbored a deep and well-placed distrust for the City Council. ${ }^{325}$

\section{“First Papers"}

Members of the City Council were not the only local officials to express a continued belief that Issei were undesirable foreigners. In July 1946, the national JACL sent a memo to all its chapters suggesting a model for public meetings to push the naturalization campaign as a way to make laws targeting Japanese immigrants obsolete. One of the strategies of the program called for a young Issei to speak about his desire for citizenship, presenting their birth in Japan as a mere technicality. In the flyers words, "this person would point out that he represents several thousand such who would jump at the chance to become naturalized Americans. ${ }^{, 326}$ Following typical tactics of the postwar JACL, the program also called for the testimony of a Nisei veteran and "prominent Caucasian."

The white speaker had a particularly important role in placing the effort in a transnational context. That speaker was to convey the benefit in eliminating discriminatory naturalization laws for "America's place of leadership in the world" while pointing out the "irony of our teaching democracy to Japan, at the same time

\footnotetext{
${ }^{325}$ Matsushima Oral History, p. 2.

${ }^{326}$ Masao W. Satow, memo to all JACL chapters, "Suggested Program for Meeting on Naturalization," 9 July 1946, Immigration and Naturalization, PDX JACL Collection.
} 
denying Japanese nationals here in America the right to become citizens." ${ }^{, 327}$ To demonstrate this to the U.S. Congressional committees considering the naturalization legislation, the national JACL directed local chapters to urge Issei to file declaration of intent forms (Form A-2213) with the Immigration and Naturalization Service (INS) as proof of their desire for U.S. citizenship. By August 1946, national JACL leaders secured an agreement with Ugo Carusi, U. S. Commisioner of the INS, that Issei would be allowed to file their "first papers" without the interference of local officials. ${ }^{328}$ Although the Portland JACL did not hold a public naturalization meeting according to the national JACL model, they dispelled misinformation about the forms like the need to file them in order to gain entrance to public housing in Vanport and publicized the effort. ${ }^{329}$

Despite the national JACL's arrangement, Portland INS official Vernor W. Tomlinson challenged the legitimacy of "first papers" for people of Japanese descent. A number of Issei from Hood River went to the Portland INS offices in late 1946 to retrieve the necessary forms to file first papers, because the Hood River office did not have the necessary paper work. When Mrs. Max Moore, a member of the MidColumbia JACL's Caucasian advisory board, called Tomlinson to investigate the reason for these extra trips, he made his anti-Japanese stance clear. The following is a transcript of the conversation Moore sent to national JACL headquarters:

Clerk Tomlinson: "You know they cannot become citizens."

\footnotetext{
327 Satow, "Suggested Program for Meeting on Naturalization."

${ }^{328}$ National Headquarters JACL, memo to all chapters, "Filing of First Papers for Naturalization by Issei," 9 August 1946, Immigration and Naturalization, PDX JACL Collection.

329 "Applicants for Citizenship," 25 March 1947, Immigration and Naturalization, PDX JACL Collection. Mary Minamoto, "JACL Will Assist with Naturalization Papers," Portland Hi-Lites, 23 October 1946, "Hi-Lites” Portland 1948, PDX JACL Collection, p. 2.
} 
Mrs. Moore: "Yes, we know that and they have been so informed, but they want to make application for their first papers and they have been told that this does not mean that they may certainly become citizens."

Tomlinson: "They will never become citizens. They belong to a race that is ineligible to become citizens."

Mrs. Moore: "So did the Chinese and they are now eligible to citizenship and we believe these people have their rights the same as any of us. There is a bill now pending in Congress which will give them the right of citizenship and these people are preparing themselves for that eventuality."

Tomlinson: "I had a boy in the South Pacific and I hope they never become citizens."

Mrs Moore: "I had a nephew wounded at Pearl Harbor and a boy the Germans nearly killed but I still think these people have as much rights as any of the rest of us."

Tomlinson: "Well, I'll send the blanks up. How many are there? Do they know they are committing perjury when they swear they want to become citizens when they can't? And I hope they will never be allowed to do so."

Mrs. Moore: "There are about forty of them. And thank you very much.,"330

This conversation does not represent the opinion of the majority of INS officials, but rather one form of resistance to Issei citizenship. His resistance echoes 1945 battles over the return of Japanese Americans in that both used their relatives' military service as proxy-legitimacy for their stance on Issei citizenship. The real argument here swings on connection to the Allied victory in World War II, while Tomlinson's argument of Japanese racial unassimilbility merits barely a response from Moore.

The episode also demonstrates a lack of institutional interest in punishing such comments. Despite a strongly worded letter from national JACL secretary Masao Satow to Carusi complaining about Tomlinson's attitude towards the parents of Nisei veterans, the INS was unapologetic. Carusi's assistant described the affair as a merely a case of a short supply of forms and makes no apology for either Tomlinson's anti-

\footnotetext{
${ }^{330}$ Mrs. Max Moore, letter to Masao W. Satow, secretary of the national JACL, 24 January 1947, Immigration and Naturalization, PDX JACL Collection.
} 
Japanese sentiment or his misleading argument that Issei filing the forms would be committing perjury. ${ }^{331}$

\section{The Alien Land Law Test Case}

The Alien Land Law test case campaign is the best example of success achieved by members of the Japanese American community working with white civic leaders in the early postwar era. Perhaps at the instigation of his wife, who was a board member for the YWCA and Citizen's Committee, Portland lawyer Verne Dusenbery formed a committee within the Multnomah Bar Association to study challenges to the constitutional rights of Japanese Americans in Oregon. ${ }^{332}$ During their study, at the urging of Governor Earl Snell, Walter Pierce, and the Japaense Exclusion League, the Oregon Legislature updated the 1923 Alien Land Law so as to "bring about uniformity in such laws with the state of California." 333

The Japanese American rights committee study concluded that the 1945 Alien Land Law was the product of economically motivated, rural Anti-Japanese groups. Those groups manipulated the "patriotic fervor engendered by the war" to buy land from Japanese Americans at cut rates and that "paradoxically as it may seem, the men in the service form one of the strongest bulwarks supporting the constitutional rights of Americans of Japanese ancestry." Furthermore, the committee claimed that the Alien Land Laws of both 1923 and 1945 were unconstitutional because even resident

\footnotetext{
331 A. C. Devany, Acting Assistant Commissioner INS, letter to Masao W. Satow, 3 February 1947, Immigration and Naturalization, PDX JACL Collection.

332 “Jap Rights Win Defense," Oregonian, 28 February 1945, p. 5.

333 "Statement about Oregon Alien Land Law, February 1945," Box 3, Folder 3, Snell Papers.
} 
alien Japanese are entitled to protection under the $14^{\text {th }}$ Amendment of the US Constitution. $^{334}$

It remains unclear why, despite such strong conclusions in favor of defending Japanese rights, a case was not filed in the Multnomah County Court challenging the law until April 1947. Historian Amy K. Buck wrote that Dusenbery teamed up with Alan Hart to craft a case that would overturn both the 1923 and 1945 statutes. In early 1947, Kenji Namba, a Nisei veteran, his father Etsuo Namba, and Florence Donald volunteered to create a lease that would draw charges from the Multnomah County district attorney. ${ }^{335}$

Two factors might explain the delay. First, the Alien Land Law Test committee did not form until April 1946 and did not collect ample funds for a test case until July 1946. ${ }^{336}$ Second, conflict between the Portland chapter and the national JACL discouraged the pursuit of individual legal attempts that might hinder legal proceedings sponsored by the national organization. According to WRA accounts, discussion among JACL leaders in 1946 largely concluded that chapters should take care not ask too much from white Americans. Quoting a meeting in Colorado in 1946:

I think if we publicize the Nisei too much the Caucasian public is going to get tired of it, and will begin to hate us...I don't think we ought to play up all the little discriminations the Japanese are experiencing. Some of them think we can simply forget... Sure we can press some cases into court, but we ought not to do it only once or so. Make it a big court fight, put a lot of money in the case, but

\footnotetext{
${ }^{334}$ Verne Dusenbery, “The Japanese Problem in Oregon,” Oregon Law Review, 24 (1944-1945), pp. 208, 217-218.

335 Amy K. Buck, “Alien Land Laws,” Master's Thesis, Portland State University, 1999, p. 79. See Buck also for a more thorough explanation of the legal issues and precedents surrounding the Namba case, as well as for a more detailed explanation of the creation of both the 1923 and 1945 Alien Land Laws.

${ }^{336}$ Oral History with Ted Hachiya, transcript, Oregon Nikkei Legacy Center Research Library.
} 
once it is over we ought to forget it and not continue to press cases into court over and over again. ${ }^{337}$

By March 1945, the JACL had already begun to support that one big case. A. L. Wirin, the law partner of national JACL executive secretary Saburo Kido, sought to overturn of the California Alien Land Law after the state filed escheat proceedings against San Diego residents Kajiro and Fred Oyama. ${ }^{338}$ In California, county governments had begun to work with state officials to file escheat proceedings of Issei-owned land in a systematic process of removal that filled municipal coffers while "releasing" valuable farmland for white use. This was a process not present in Oregon. ${ }^{339}$

While the Oyama case was awaiting its hearing in the U.S. Supreme Court in April 1947, Wirin paid a visit to the Portland chapter as a part of a fund raising campaign that began in January $1947 .{ }^{340}$ Wirin was crestfallen when he learned that a case had already been filed in Multnomah County court, thus making use of the ample funds collected by the Alien Land Law Test Case Committee in 1946. He later wrote to the Portland chapter president that he thought the case was not advisable, but since it was filed already there was nothing to do but support it. ${ }^{341}$ Wirin's support was tacit approval, not legal and financial support. Given earlier conflicts with the national JACL and the fact the Portland JACL did not advertise the case as one of its

\footnotetext{
${ }^{337}$ Quoted in War Relocation Authority, People in Motion: The Postwar Adjustment of the Evacuated Japanese Americans, Vol 5, (New York: AMS Press, 1947), p. 212.

338 "California's Supreme Court Asked to Rule State's Alien Property Legislation Invalid," Pacific Citizen, 16 March 1945, p. 3.

${ }^{339}$ Larry Tajiri, "Reviving a Dead Letter," Pacific Citizen, 16 February 1946, p. 4.

${ }^{340}$ Hito Okada, "Statement," 9 January 1947, Bulletins, PDX JACL Collection.

${ }^{341}$ A. L. Wirin, letter to Toshi Kuge, 26 April 1947, Correspondence of the President, PDX JACL Collection. In addition to his role as legal aid closely associated to the national JACL, Wirin acted as fund raiser for test cases as early as 1944 when he offered legal aid to Japanese Americans seeking to evade the draft, charging one hundred dollars per person, which they often had to borrow from family. See Brian Masaru Hayashi, Democratizing the Enemy: The Japanese American Internment, (Princeton, NJ: Princeton UP, 2004), p. 184.
} 
achievements, it seems likely that they had little to do with the Namba case. ${ }^{342}$ Instead, the ten members of the Test Case Committee, including Takeoka and Hachiya, were left to organize the case by themselves, drawing out the process considerably. In 1949, the case was successful, overturning both the 1923 and 1945 Alien Land Laws.

\section{The Portland Anti-Discrimination Committee}

JACL efforts in Portland continued to follow the national model in the 1947 creation of the Portland Anti-Discrimination Committee (PDX-ADC). In December 1946, the Portland JACL sent George Azumano and Kimi Tambara to the West Coast Action conference in San Francisco. At the conference, Mike Masaoka answered concerns that the JACL would just be another social organization with a renewed national civil rights campaign. He wanted to make JACL a stronger organization so it could "be strong enough to be able to meet any crisis which might arise." He proposed the creation of a national network of Anti-Discrimination Committees with two purposes: local ADCs would allow Issei membership, creating a direct funding stream from Issei at the local level; and local ADCs would cultivate contacts among the white community and serve as a network mobilizing local Congressmen and government officials to support national legislative campaigns. The ADC was to be the direct action group, while the JACL would be a "fraternal and educational organization." Masaoka called on JACL chapters to collect $\$ 67,000$ to finance the project. ${ }^{343}$

\footnotetext{
${ }^{342}$ See "Portland Chapter JACL Activities," PDX Minutes, PDX JACL Collection.

${ }^{343}$ This funding scheme also required local JACL chapters to give up quite a bit of potential donations from Issei, who would have been more interested in the ADC program than the JACL. Part of the rational for creating two funding streams was valid though. Masaoka and others were worried that lobbying in Washington D.C. would brand the JACL as a political organization, thus endangering their tax-exempt status. "Report to the Northwest District Council JACL: West Coast Action Conference,
} 
Masaoka's funding campaign mirrored the relationship between the Portland JACL and the Issei members of the Koenkai, which established a direct funding link between the Portland Issei and Masaoka's lobbying efforts. Shifting funding to national projects was a challenge to Portland JACL's funding scheme, because Issei donations to the JACL dwarfed Nisei financial contributions in 1946 and 1947. For instance, the total membership dues in those two years amounted to $\$ 305$ and various other fund-raising events netted \$750. The Koenkai, on the other hand, donated \$2940. This donation did not include the $\$ 17000$ raised for the Alien Land Law Test Case Committee. Issei contributors followed through on their earlier pledge to support the Portland JACL financially by paying their operating costs, the $\$ 1000$ levy asked for by the national JACL, and left them with about $\$ 1000$ extra in their treasury. ${ }^{344}$ After Azumano founded the Portland ADC, concurrent with his election as Portland JACL president, in April 1947, there was little reason for Issei to continue donations to the $\mathrm{JACL}^{345}$

Masaoka planned to make up for losses in JACL revenue with a national membership drive. Besides the need for additional funds, membership was a chronic problem for the JACL in the immediate postwar years. According to a membership

San Francisco, CA, 7-8 December 1946," Pacific Northwest Council, PDX JACL Collection, p. 1. Hereafter called "San Francisco Report."

${ }^{344}$ These funds also paid for the Portland JACL to take care of projects that would later become the responsibility of the Japanese Ancestral Society. For instance, This Koenkai funds also paid for one of the largest concerns of the Issei, the Japanese cemetery. The Portland JACL budget included \$50 spent on security guard and \$7.22 for watering. Milton Maeda, "Profit and Loss Statement Ending November 30, 1947" (Includes all funding matters after refounding of chapter in May 1946)

345 "Minutes," PDX JACL Collection. It seems enough JACL chapters and Issei were confused about the distinction between membership in the JACL and membership in the ADC that the national JACL had to send a memo reiterating that Issei could not become "Associate members." Issei were only allowed to join the ADC. National JACL, "Memorandum \#17", 18 June 1947, Memos from National Headquarters, PDX JACL Collection. 
campaign guide produced by the national JACL, before World War II the national JACL had twenty thousand members. In early 1947, despite the fact that many more Nisei, having turned eighteen, were eligible for membership, national membership dropped to less than three thousand. ${ }^{346}$ In Portland there were only thirty-two members before the membership drive. ${ }^{347}$

Small membership in the JACL in 1946 and 1947 was also a problem of legitimacy for a group that often claimed they were the only group fighting for Japanese American constitutional rights. ${ }^{348}$ Both the national and Portland JACL worried that low membership would undermine the national legislative program. In a national JACL bulletin on the 1947 membership drive, leaders complained:

One of our major emphasis [sic] is to get some national legislation through Congress. 3000 people, or just a handful, have no business undertaking the job we are attempting to do. From the standpoint of congressmen, 3000 people aren't worth the time and effort. As Mike Masaoka contacts national organizations, and government agencies, he is asked, 'how many people do you represent?' There are those Nisei among us who resent the JACL representing them without their permission, so to be honest, Mike must say that he represents the actual numbers who are signed up as JACL-ers. You can imagine the kind of rejection this response gets and how sick at the stomach Mike feels. ${ }^{349}$

In 1947 Mike Masaoka spearheaded a lobbying campaign in Washington D. C. to pass legislation including HR 3149, Soldier Brides Amendment, HR 3555, naturalization

\footnotetext{
${ }^{346}$ National JACL, "Membership Campaign Must Be Organized," 3 January 1947, Correspondence of the Membership Chairman, PDX JACL Collection, p. 2. Here after called Membership Campaign

${ }^{347}$ Milton Maeda, "Portland JACL Membership," January 1947, Correspondence of the Treasurer, PDX JACL Collection.

${ }^{348}$ Other groups who supported Oregon Nikkei took exception to such statements. For instance, in November 1947 George Azumano invited Phil Dreyer of the American Veteran's Committee to a dinner in honor of Mike Masaoka in Portland. In the invitation, Azumano claimed the JACL was the only organization fighting for Japanese American civil rights, a claim Dreyer made the point of disputing in a response letter. There is some evidence, although not conclusive, that several returning Nisei had close ties with the Portland Council American Veterans Committee. Phil Dreyer, letter to George Azumano, 11 November 1947, PDX JACL Collection.

${ }^{349}$ Membership Campaign, p. 3.
} 
for Issei, HR 3566, removing race factors from deportation laws, and HR 3999, the evacuation claims bill. The JACL knew that sympathy for the wrongs of internment as juxtaposed with the Nisei Patriotism argument would only get these bills so far in the U.S. Congress. High membership rolls were needed to prove that Japanese Americans were an organized constituency in need of consideration. Later in the bulletin, JACL leaders linked the membership problem to the legislation campaign more explicitly:

IF JACL FAILS IN ITS EFFORTS THIS YEAR [1947] FOR THE NATIONAL LEGISLATION, IT WILL BE BECAUSE THE MAJORITY OF NISEI DON'T GIVE A DAMN... [all capitals in the original]...if the Japanese Americans show only lukewarm interest, what right have we to expect our friends to go to bat for us? What answer can we give to our fellow Americans of good will and the Issei who support us when they ask, "If your program is so vital and important, why don't the Nisei themselves support it?"350

Nisei seemed to see little benefit in supporting the JACL; that is not to say Nisei did not follow news of JACL efforts. In 1947, 1,600 JACL members had subscriptions to the national JACL newspaper Pacific Citizen. The Pacific Citizen's total circulation, however, was $6,500 .^{351}$

The Portland JACL's frustrations with the membership drive were also tied to their 1947 fundraising campaign in that both reflected a distinct lack of interest in supporting the JACL on the part of Portland Nisei. First of all, correspondence with other JACL chapters led to frustrating comparisons in terms of membership. For instance, the Milwaukee, Wisconsin, chapter claimed that seventy-five percent of

\footnotetext{
${ }^{350}$ National JACL, "Membership Campaign Must Be Organized," 3 January 1947, Correspondence of the Membership Chairman, PDX JACL Collection, p. 3. Here after called Membership Campaign.

${ }^{351}$ Membership Campaign, p. 2.
} 
Nisei in Milwaukee had become members. ${ }^{352}$ Although Portland membership more than tripled, growing to 115 in 1947, the representation was nowhere near Milwaukee's numbers. ${ }^{353}$ In the 1947 JACL fundraising drive, staffed mainly by Issei, Mary Minamoto, along with Azumano and Hachiya, often found themselves in an awkward position when asked by Issei leader Iwao Oyama why Nisei were not joining the JACL or canvassing for donations needed for local JACL operations and the national JACL legislation campaign. Minamoto complained bitterly about the problem in Portland Hi-Lites:

Surely if we are able to raise funds for athletics, etc., we must be able to raise funds for the national program too. "Isseis [sic] are benefiting from the nationals program" cries the Nisei but remember Niseis [sic] were not exempted from evacuation. Issei problems proved to be our problems and will remain to be one until we learn to combat them. ${ }^{354}$

In 1947, Portland Nisei reestablished the Nisei Bowling league, with local businesses sponsoring teams, but were apparently largely uninterested in the political activities of the JACL. ${ }^{355}$

Despite the JACL commitment to telling the story of the $442^{\text {nd }}$ Regimental Combat Team, the ranks of uninterested Portland Nisei included Nisei veterans. In a separate Portland Hi-Lites article, Minamoto castigated Nisei veterans for failing to attend the first annual convention of the Oregon and Southern Washington Council American Veterans Committee. She claimed that no Nisei veterans attended.

\footnotetext{
${ }^{352}$ M. Kaneko, Letter to Milton Maeda, 6 June 1946, Correspondence of the Treasurer, PDXJACL Collection.

353 "Northwest District Council Minutes," 8 June 1947, Pacific Northwest Council, PDX JACL Collection, p. 4.

${ }^{354}$ Mary Minamoto, “Help Thyself...," Portland Hi-Lites, 17 February 1947, p. 3.

${ }^{355}$ Nakata, p. 142.
} 
Furthermore, she revealed that no Nisei veterans, besides the veteran from Arizona they paid to come, attended the Purple Heart Convention in the fall 1946, which was the first postwar project of the Portland JACL. ${ }^{356}$ Part of the point of the 1946 convention was to encourage Nisei veterans to join other veterans organizations, like the American Legion and Veterans of Foreign Wars, thus allowing other American soldiers to meet Nisei veterans and cultivate more good will for all Nisei.

Faithful to this cause, Toshi Kuge, first president of the postwar Portland JACL, and fellow Nisei veteran and JACL member Jimmy Mizote, attempted to join the Portland American Legion Post \#1 in 1946. However, in a continuation of wartime anti-Japanese attitude, the post did not accept their membership and told them to start their own group. ${ }^{357}$ In 1947 , Toshi Kuge organized 25 Nisei veterans who met at the Japanese Methodist church to found their own organization, the Nisei Veteran's Committee. ${ }^{358}$ Afterwards, it seems, they were uninterested representing the Nikkei community to white audiences.

A lack of interest in JACL activities extended to JACL members as well. One of the greatest problems for individual JACL chapters in the early postwar years was that nominations to chapter offices, especially president, were constantly turned down. At the end of 1947, when the Portland chapter nominating committee tried to find candidates, a large number turned down nominations claiming to be either to busy or uninterested. Frustrated by the process, 1947 Portland JACLVice President Paul Oyamada wrote Mas Satow, JACL national secretary, asking for help in persuading

\footnotetext{
${ }^{356}$ Mary Minamoto, "Battle Not Won...," Portland Hi-Lites, 10 March 1947, p. 4.

${ }^{357}$ Nakata, p. 143.

${ }^{358}$ Toshi Kuge, "Veterans! Forward! March!," Portland Hi-Lites, 10 March 1947, p. 6.
} 
members to accept leadership. Satow replied that the problem was widespread, mentioning how the lone candidate in Los Angeles withdrew after he was elected. Furthermore, in Chicago five members turned down the presidency in $1946 .{ }^{359}$ Ironically, in 1948, Oyamada turned down a position as leader of the Political Action committee of the Portland JACL, although he agreed to maintain a role as speaker before other organizations and member of the deputation committee of the Portland JACL-ADC. ${ }^{360}$

Often in early postwar Portland, Nisei leaders like Azumano, Oyamada, and Hachiya embraced the JACL-ADC's letter-writing network and an opportunity to work with outside groups on broader social justice issues. The JACL-ADC followed the model laid out by national leaders in the Membership Campaign bulletin as follows:

1. Receive information emanating from Washington. (Here after Progress Reports will be sent to the Chairman of the Anti-Discrimination Committee instead of the Chapter President)

2. Keep local people informed of developments.

3. Plan and activate local action in cooperation with the National Legislative program.

4. Keep the Washington ADC office informed of local developments that may have bearing upon the priorities adopted by ADC as outlined in "Statement by Mike Masaoka, Director of JACL ADC January 7, 1947.”

5. Cooperate with the local Chapter Public Relations Committee in the cultivation of strategic contacts in the community.

6. Recruit additional memberships and solicit funds for the Anti-Discrimination Committee $^{361}$

\footnotetext{
${ }^{359}$ Mas Satow, Letter to Paul Oyamada, 8 December 1947, Nominating Committee, PDX JACL Collection.

${ }^{360}$ Paul Oyamada, Letter to Portland JACL President Toshi Kuge, 12 April 1948, Nominating Committee, PDX JACL Collection.

${ }^{361}$ The "statement of Policy" memo referred to here lays out two guidelines for the JACL. First, the JACL was to be a group for any U.S. citizens. Second, it directed JACL members to take on only social justice issues related to Japanese Americans when in their organizational roles. To avoid conflicts between Nisei on the rights of other minorities, JACL members were only to stand up for other
} 
These guidelines called for a direct information pipeline to Masaoka in Washington as well as an ideological commitment to his strategy in securing pro-Japanese legislation. In the days before crucial votes in U.S. Congress, such as the Evacuation Claims act in 1948 and versions of legislation designed to secure citizenship for Issei like the successful Walter-MacCarran Act of 1952, Masaoka would send a telegram to a local ADC office calling on white community leaders to write their congressional officials. Collectively, these leaders were often called the "Caucasian advisory board." 362 Later, Masaoka explained the role of these advisory boards more explicitly:

It is suggested that every chapter arrange to have a group of non-Japanese friends who know the congressmen personally to call upon them and urge them to support our legislative program. Such deputations should be followed up by a group of chapter members calling upon these same congressmen....Members of any deputation should be thoroughly grounded in the background and the reasons for this legislation. This is particularly true for our non-Japanese friends. No Nisei should be in these groups, in order that these non-Japanese citizens can call upon congressmen as constituents and friends.

They were also encouraged not to pressure congressmen. They were trying to encourage friendly interaction on the issue. ${ }^{363}$ In a sense the national ADC sought a grass roots movements of white advocates for civil rights, with local Nisei playing a supporting role.

minorities in an unofficial capacity. In an interesting closing, the memo also claimed that the JACL only served to end discrimination against Japanese Americans, until their situation was similar to other American groups, at which time they would disband. National JACL, "Memorandum \#4," 5 February 1947, Memos from National Headquarters, PDX JACL Collection. People in Motion, pp. 209-210. 362 "Northwest District Council Minutes," 8 June 1947, Pacific Northwest Council, PDX JACL Collection, p. 12.

${ }^{363}$ Japanese American Citizen's League Anti-Discrimination Committee Inc, "Interim Project," 25 August 1947, Memos from National Headquarters, PDX JACL Collection. 
In 1947 and 1948, Azumano, as head of the Portland-ADC, tasked a deputation team to write up a contact list for the Caucasian advisory board to be sent to the national offices. The effort was an attempt to ensure continued support of Portland Citizen's Committee Members, progressives like Gus Solomon and Monroe Sweetland, and Portland civic leaders like E. B. MacNaughton, who spoke out against the Japanese Exclusion League in 1945. The list also included former missionaries to Japan, like Alice Finley and Cora Oliver, local labor leader Irving Enna, and African American Edwin Berry of the Portland Urban League. ${ }^{364}$ Minamoto, who served on the deputation team, expressed some concern in sending their list to the national JACL because she knew they would be asked to "write, wire or telephone their Representatives or Senators when requested to do so by Washington, D. C. Office [ADC]." Minamoto knew they would be asking a lot of their Caucasian friends, so she proposed to ask every member on the list if they would be willing to help. ${ }^{365}$

Responses to these letters are telling of perceptions of Japanese American in the Portland community in 1948. For instance, Marshall N. Dana, editor of the Oregon Journal editorial page, responded:

I think there is a great deal of justice in the appeal for the grant of citizenship to those Japanese born in Japan who have demonstrated their loyalty to the United States and who are themselves parents of loyal American-born Nisei. I doubt, however, the desirability of pressing a measure of this kind until the effectuation of the peace treaty between Japan and the United States. ${ }^{366}$

\footnotetext{
364 "Untitled," Caucasian advisory board list, Movie "Challenge to Democracy," PDX JACL Collection.

${ }^{365}$ Mary Minamoto, Letter to Paul Oyamada, 20 February 1948, Anti-Discrimination Committee, PDX JACL Collection.

${ }^{366}$ Marshall N. Dana, Letter to Toshi Kuge, 26 April 1948, Anti-Discrimination Committee, PDX JACL Collection.
} 
Although Dana had spoken out in favor of Japanese American rights on his paper's editorial page and to audiences at a Portland JACL rally in February 1942, calling for tolerance for "Americans with Oriental faces," he was unwilling to advocate for Nikkei after the war. ${ }^{367}$ His refusal reveals the transnational position that he saw Japanese Americans occupying. He saw them as a bridge to Japan. Thus their fate could not be decided until the postwar relationship between the U.S. and Japan was again firmly established. Presumably, many former members of the 1945 pro-Japanese alignment, such as Governor Charles Sprague, felt the same way and opted not to join the Caucasian advisory board.

\section{“Other Groups"}

Occasionally, the Portland ADC used the Caucasian advisory board to help support broader legislative efforts. For instance, Azumano wrote members of the board in 1947 to support the Oregon Fair Employment Practices (FEP) Bill of 1947, HB 385. ${ }^{368}$ The successful bill set up a labor board to ensure equitable employment for women and minorities. Coincidentally, one of the first instances of public controversy over employers ignoring the bill involved a Japanese American as well. In 1951, disabled Nisei Veteran Sagie Nishioka scored the highest on a civil service exam of three candidates for a job with the state tax commission. The commission decided, however, not to hire Nishioka in the belief that the public would not want to deal with

\footnotetext{
${ }^{367}$ Portland JACL, “Summarized Report of the JACL Rally,"JACL Activities 1941-1942, PDX JACL Collection.

${ }^{368}$ George Azumano, Open letter to "Fellow Citizens," 20 March 1947, Veterans 1947, PDX JACL Collection.
} 
a Nisei clerk. After the Oregonian ran a series of articles about how the state tax commission violated the FEP law, the tax board was forced to offer him a job. ${ }^{369}$

Cooperation with the Portland African American community by Portland JACL and ADC members was small and on a personal basis. Azumano served as a Nisei representative to the Portland NAACP and used the letter-writing network to support Anti-Lynching legislation in the U.S. Congress in $1947 .{ }^{370}$ Paul Oyamada served on the Masaoka-sponsored Civic Unity Council, but the effort failed in Portland due to lack of local support by Portland Mayor Earl Riley. ${ }^{371}$ Oyamada instead served on the Speaker's Bureau for the Portland Council of Churches, along with Reverend Francis M. Hayashi, speaking to local churches and civic groups. ${ }^{372}$ This largely religious group functioned much like the Seattle Civic Unity Committee, providing education on issues of discrimination in Portland.

\section{A Minority Like Any Other}

The Portland JACL and Portland-ADC suffered a severe lack of participation and had a restrictive relationship with the national JACL, limiting their capacity to aid Portland Nikkei. However, Portland JACL leaders approached two cases of

\footnotetext{
369 "Nisei Accepts Job in Salem: Veteran to Become Junior Accountant," Oregonian, 3 April 1951, p. 11.

${ }^{370}$ Azumano became involved after George Thomas, of the Portland Council of Churches and the Portland NAACP, asked him to send out the word that Herbert Peet had planned a lecture on the subject. George L. Thomas, Portland Branch NAACP, Letter to George Azumano, 3 June 1947, Other Organizations, PDX JACL Collection.

${ }^{371}$ Seattle's mayor William F. Devin, on the other hand, responded to public concerns about interracial conflict by creating the Seattle Civic Unity Committee. The committee was designed to ease interracial tensions, disseminate information, and make recommendations to the mayor's office on race issues. See, Quintard Taylor, The Forging of a Black Community: Seattle's Central District from 1870 Through the Civil Rights Era, (Seattle: University of Washington Press, 1994), pp. 167-168. "Compiled Report, January-September 1945," Box 3, Folder 3, Snell Papers, p. 3. "Minutes," PDX Minutes, PDX JACL Collection.

${ }^{372}$ Division of Social Relations, Portland Council of Churches, "Social Action Program Guide," Speaker's Bureau, PDX JACL Collection.
} 
discrimination, similar to issues faced by the Portland African American community, with particular effectiveness: Nikkei blood segregation and aid to refugee Japanese Americans in the aftermath of the flooding of the Vanport housing projects in 1948.

One of the greatest indications that military service by African Americans and Japanese Americans did not ensure equality was the segregation of blood by race in World War II and after. For instance, blood sent by the Red Cross to the European front had to be segregated by race. By the beginning of World War II, scientists had definitively proved that race played no significant factor in blood type. Despite this, public conceptions about blood difference persisted, so the U.S. War department advised military authorities not to mix blood, even though they knew there was no basis for the segregation. Blood segregation by the Army and the Red Cross continued until December $1950 .{ }^{373}$

The blood supply in Portland was not only divided between black and white supplies, but Japanese as well. In August 1946, Dr. Robert Kinoshita discovered that the Portland blood bank was short of Japanese blood, so he contacted national JACL president Hito Okada to find out how to proceed. ${ }^{374}$ Soon after the Portland JACL encouraged members to give blood and join a blood-donors list as a way to fill the need without publicly challenging the absurdity of blood segregation in the short term, while working to solve the problem in the long term. Archival records do not reflect when Nikkei blood segregation ended, but by June 1947, Dr. Rieke at the Vanport hospital JACL member Juneus Oba began a campaign to found a blood donor service

\footnotetext{
${ }^{373}$ William H. Schneider, "Blood Transfusion Between the Wars," Journal of the History of Medicine and Allied Sciences, Vol. 50, Issue 2, pp. 220-222.

${ }^{374}$ Hito Okada, letter to Mary Minamoto, 21 August 1946, Purple Hearts Convention Testimonial Dinner, PDX JACL Collection.
} 
that ignored the color line. ${ }^{375}$ Mary Minamoto's column provides a window into

Portland JACL sentiment on the issue:

Obviously the above program is an adoption of existing Jim Crow practices as now exist in many Portland medical quarters but faced with the dilemma of aiding persons in distress under existing circumstances, it is felt that for the present, at least, a donor list for Japanese ancestry persons is a practical approach to the problem in that immediate results are obtained. However, such a setup should not be permanent as the pattern tends to become entrenched. So it has been gratifying to learn that a committee of the Mult. County Medical Society has been working on a community wide blood bank to be available to all Portland Community members irrespective of race, color and creed. ${ }^{376}$

Minamoto demonstrated a firm belief in Portland's turn toward civic nationalism.

Whereas Japanese Americans faced a broader type of Jim Crow style racism, she had faith that such discrimination was temporary.

Racial restrictions and discriminatory sales practices by Portland realtors prohibited African Americans and Japanese Americans alike from renting or purchasing homes in white neighborhoods. ${ }^{377}$ Housing was hard to come by for Japanese Americans because of a large wartime increase in Portland's population, as well as a restriction in the Portland Realty Board's code that barred realtors from selling to minorities on the grounds that it would lower home values. ${ }^{378}$ As a result, 900 Japanese Americans, the majority of the postwar Portland Nikkei population,

\footnotetext{
${ }^{375}$ Richard K. Stanton, Multnomah County Medical Society, Letter to Toshi Kuge, 2 October 1946, PDX JACL Collection. Abe Oyamada, Letter to George Azumano, 13 June 1947, Speaker's Bureau, PDX JACL Collection.

376 "Blood Donors List," Portland Hi-Lites, 14 November 1946.

${ }^{377}$ Rudy Pearson, "A Menace to the Neighborhood: Housing and African Americans in Portland, 19411945," Oregon Historical Quarterly, Vol 102, No. 2, p. 160.

${ }^{378}$ See Part III Article 34, "A realtor should never be instrumental in introducing into a neighborhood a character of property or occupancy, members of any race or nationality, or any individuals whose presence will clearly be detrimental to property values in the neighborhood." Portland Realty Board, "Constitution and By-Laws, Code of Ethics," 7 April 1948, Mss 1511 Portland Realty Board, Box 35 Folder 6, Oregon Historical Society Research Library, p. 28.
} 
lived in the Vanport Federal wartime housing development. ${ }^{379}$ Some realtors were willing to canvass neighborhoods to make sure white neighbors would not object to Nikkei moving in, reminding Japanese Americans that they were not welcome in a majority of Portland's neighborhoods. ${ }^{380}$ Subsequently, home ownership by Japanese Americans in Portland was only about two percent and Portland Nikkei tended to be segregated in the two former Portland Japan towns. ${ }^{381}$

Groups like the Urban League and Portland Council of Churches had long protested housing discrimination, but Mayor Riley and Chester Moores, his appointee to the Housing Authority of Portland (HAP) were uninterested in actions opposed by realtors. Because Moores believed industrial uses were much more profitable, and that the HAP's main purpose was to make money for Portland developers, they saw fair housing for minorities as a liability. Despite the lack of available housing, Moores even wanted to close Vanport so that its land could be sold to industrial developers. ${ }^{382}$ Riley hoped the nonwhite residents would just leave after the war, and had a plan in place to evict them from Vanport. ${ }^{383}$

An ugly public debate over the fate of Vanport was averted by catastrophe when the entire city of Vanport was destroyed by flood on 30 May 1948. Despite days of

\footnotetext{
${ }^{379}$ Although the majority of residents of Vanport were white, 12,600, Vanport was largely perceived by white Portlanders as an African American settlement, although they made up only 5,000 of residence. Portlanders thus understood Vanport as a threat in terms of future racial conflict in Portland. Disaster Committee Report, Portland-Multnomah County Chapter, American Red Cross, "Vanport City Flood," Series 6 Vanport City, Subseries 1 The Flood 30 May 1948, Vanport Records, 1946-1973, Portland State University Special Collections, p. 10. Heather Fryer, Perimeters of Democracy: Inverse Utopias and the Wartime Social Landscape in the American West, (Lincoln, NE: University of Nebraska Press, 2010), p. 65.

${ }^{380}$ Nakata, p. 135.

${ }^{381}$ George Azumano, Letter to Robert B. Pitts, Assistant Regional Economist, Federal Public Housing Authority, 19 June 1947, PDX JACL Collection.

${ }_{382}$ MacColl, p. 593-598.

${ }^{383}$ Pearson, p. 174, MacColl, p. 596.
} 
advance notice of severe flooding to the Red Cross and Portland leadership, Vanport was not evacuated ahead of the breach of a railroad dike. The HAP even distributed flyers to Vanport residents claiming that there was no immediate danger of flooding. ${ }^{384}$ In the aftermath of the flood the Portland JACL opened a relief station at the J. K. Kida electronics store with the aid of the Red Cross. Thankfully, the majority of Japanese Americans living in Vanport harbored enough distrust for Portland leadership to not trust HAP flyers. 550 of the 900 Nikkei Vanport residents left ahead of the flood, though many had only left for the day to attend Memorial Day services at the Rose City Japanese Cemetery. ${ }^{385}$ Alan Hart, lawyer for the Namba test case, was on his way to Vanport the morning of the flood to convince holdouts to leave before the dike broke. ${ }^{386}$ Nearly all Nikkei residents escaped harm. Photographer Sadao Mizuno and Izumi Oyama, Issei leader Iwao Oyama's wife, who was hard of hearing, were unfortunately among the few casualities of the flood. ${ }^{387}$

The Vanport disaster was also a good example of the way the JACL could facilitate cooperation with white civic groups. ${ }^{388}$ Close connections with the Red Cross by JACL members facilitated quick formation of a refugee shelter and aid center at J. K. Kida electronics store so that the mostly non-English speaking Issei would not have to go to Red Cross headquarters for aid and even provided the funds for Red

\footnotetext{
${ }^{384}$ Richard L. Neuberger, "Housing Dispute in Aftermath of the Vanport Disaster," New York Times, 11 July 1948.

${ }^{385}$ Toshi Kuge, Letter to Eiji Tanabe, 5 June 1948, PDX JACL Collection. Nakata, p. 145.

${ }^{386}$ Linda Lesowski, "Vanport Remembered," Oregonian, 21 May 1978, Northwest magazine Section, p. 10.

387 Oregon Nippo, 8 June 1948. Nakata, p. 145.

${ }^{388}$ Not only did the Red Cross have a strong presence in WRA camps, leading to general association with JACL leaders like Milton Maeda, Mary Minamoto, Portland JACL secretary worked for the Portland-Mutlnomah County Chapter Red Cross. Abe Oyamada, Letter to Mary Minamoto, 26 November 1951, PDX JACL Collection.
} 
Cross aid to homeless Issei. ${ }^{389}$ Members of the Japanese American community took in the majority of refugees, many of whom stayed at Epworth Methodist and Nitiren Buddhist Church, just as they did in the earliest days of the Japanese American return to Portland.

The nation-wide network of JACL and ADC chapters collected donations for refugees, netting $\$ 9,400$ after national JACL president Hito Okada sent out a bulletin seeking aid for Vanport flood victims. ${ }^{390}$ The funds went to refugees quickly. Within a week of the Vanport flood the Portland JACL had received almost $\$ 7,000$ in donations, and the Portland Issei-Nisei Vanport Relief Committee had already distributed \$5,200 of the funds. ${ }^{391}$ In the weeks after the flood the Portland JACL saw a surge in membership and community support due to the aid of JACL chapters from over the U.S. $^{392}$

\section{A Stronger Portland JACL?}

Surprisingly, after the upswell of support for the Portland JACL in June 1948, the chapter went inactive for three years. ${ }^{393}$ Two factors explain the chapter's dormancy. First, with the Portland-ADC framework of funding and letter writing in place, there were few local causes to rally behind. Masaoka saw the national

\footnotetext{
389 "Vanport City Flood," p. 31. For an account of a family that took in an elderly Vanport refugee, see Making Home From War: Stories of Japanese American Exile and Resettlement, Brian Komei Dempster Ed, (Berkeley: Heyday, 2011), pp. 31-56.

${ }^{390}$ The donation of $\$ 3,000$ from the Snake River JACL was particularly notable. "JACL Chapter Donations Received by Portland JACL for Nisei-Issei Vanport Flood Relief Committee," and Samuel Ishikawa, Letter to Toshi Kuge, 10 June 1948,Vanport Donations from JACL Chapters, PDX JACL Collection.

${ }^{391}$ I refer to this committee as a JACL venture because Portland JACL president Toshi Kuge chaired the committee and the large majority of donations came from other JACL chapters."Donations: Vanport Flood Relief Fund as of June 5, 1948," Vanport Flood: Thank You Letters, PDX JACL Collection. ${ }^{392}$ Toshi Kuge, Letter to A1 Tsukamoto, 16 June 1948, Vanport Donations from JACL Chapters, PDX JACL Collection.

${ }^{393}$ Dick Akagi, Letter to Mas Satow, 1 February 1951, PDX JACL Collection.
} 
legislative campaign, for Issei naturalization and the Evacuation claims Act as the main goal of these networks.

The national JACL and ADC, since the beginning of internment, had ignored or strongly discourage civil rights efforts, including Min Yasui's test case, the motion to overturn the Portland municipal business license ban, and the Alien Land Law Test Committee. While many other Issei and Nisei in Portland were interested in broader social justice issues, for all minorities, the Portland JACL encouraged participation in such efforts only on an individual basis. The demands on JACL leaders were particularly heavy, so when new leaders failed to volunteer for positions in 1948, Kuge, Azumano, and others chose to focus more on their careers and families. Other Portland JACL leaders, like Minamoto, continued their work on Nisei civil rights. Furthermore, she continued to aid local Nikkei filing claims under the Evacuation Claims Act of $1948 .{ }^{394}$

The second factor was financial. The ADC financial pipeline bypassed the Portland JACL. Therefore, when the chapter became inactive in 1948, national ADC leaders did not need to contact the Portland JACL, they merely wrote Issei leaders Daiichi Takeoka, Iwao Oyama, and Masuo Yasui. ${ }^{395}$ That is until the Issei funding pipeline started to run dry. National JACL leader Mas Satow told Azumano, "In this connection [the ADC debt], I understand that Portland does have some money on hand in its treasury, and I am wondering if the Portland Chapter can help us out."396 The

\footnotetext{
${ }^{394}$ Mas Horiuchi, Letter to Mary Minamoto, 15 December 1949, Circulars, PDX JACL Collection.

395 Toshi Kuge, Letter to Mike Masaoka, 17 May 1948, Anti-Discrimination Committee, PDX JACL Collection.

${ }^{396}$ Mas Satow, National Director JACL, Letter to George Azumano, 1 February 1951, loose material, PDX JACL Collection.
} 
Issei funding connection through the ADC, it seems, was starting to run dry. Therefore, the Portland chapter met again shortly after receiving the letter to elect leaders, though no one showed interest in taking on the presidency until March when Azumano “railroaded" Dr. Matthew Matsuoka, a Nisei with no prior experience with the JACL, into the position. ${ }^{397}$ Thereafter, the chapter was much more active, but funding continued to be a problem. Meanwhile local Japanese American businessmen focused on building up successful businesses, such as the Azumano Insurance and Travel Agencies, Umata Matsushima's Anzen store and importing, Ted Hachiya's Byron's Furniture, and Bill and Sam Naito's Norcrest China.

397 "Names and News Portland JACL," p. 2. 


\section{Chapter 6: Conclusion}

After laying out the social and political environment in postwar Portland, the reformation of the Portland JACL, and arguments made by the Japanese Americans for acceptance and social justice after World War II, several questions of significance remain. The return of Japanese Americans to Portland is more than a story of rebuilding community after an unjust incarceration. Debates over the return of Japanese Americans in 1945 highlight a schism between progressives, a shift to civic nationalism, and the strengths and limitations of minority groups' appeals to patriotism based on service to the armed forces in World War II.

Placing Japanese Americans at the center of a narrative of Oregon progressivism in the 1930s recovers figures such as Oregon Governor Walter M. Pierce from a historical narrative of paradox. Pierce's transnational, racially exclusive progressivism sought to protect Oregon's white producer class of farmers and workers from conservative Portland business interests such as the Portland Chamber of Commerce, and preventing Asian immigration that he believed posed a racial and economic threat. For Pierce advocacy for public power and Japanese exclusion both furthered the goal of protecting Oregon producers.

During the 1930s, support for the New Deal and public power brought Pierce and the Oregon State Grange into alliance with labor leaders and civil rights progressives, such as Gus J. Solomon and Monroe Sweetland in the Oregon Commonwealth Federation (OCF). Sweetland and Solomon failed to protest Japanese 
incarceration in 1942 after the failure of a series of key public power ballot initiatives in 1940, which proved to be the death knell for the OCF. Following the collapse of the OCF alliance in 1940, civil rights progressivism faltered in Oregon because of a lack of organization and the defection of Pierce and others who used the Pearl Harbor incident as a pretext to support the exclusion of Japanese Americans.

Between 1942 and 1945 a debate in public and in the press over the right of Japanese Americans to return to Oregon embodied a shift from racial nationalism to civic nationalism. Although the American Legion, the Portland City Council, Pierce, Oregon Legislator Thomas Mahoney, and the Japanese Exclusion League all argued that Japanese Americans held racial loyalty to the Japanese Empire and must not be allowed to return to Oregon, their calls were unsuccessful. Civic leaders, such as banker E. B. MacNaughton, religious groups like the Portland Council of Churches, the lawyer Solomon, the Portland Citizen's Committee to Aid Relocation, and returning white soldiers won the day by branding anti-Japanese organizers as fascists. The loudest proponents for one-hundred-percent-Americanism were the ones branded as un-American by summer 1945.

Portland's shift to civic nationalism excised Asian exclusion from the bounds of publicly acceptable progressivism while expanding the definition of Americanism to include Japanese Americans. Racial exclusion was no longer an acceptable public argument and Pierce became a rural, reactionary relic of an earlier age of intolerance. Solomon, who became the head of the Oregon ACLU in 1944, and other civil rights progressives, continued to support rural public power efforts, but more actively 
pursued civil rights reform in the postwar. ${ }^{398}$ For instance, in 1950 the Progressive Party of Oregon wholeheartedly supported an effort by Portland Mayor Dorothy McCollough Lee to remove the controversial "white trade only" signs from downtown hotels and restaurants. An article in the Oregonian reveals disdain for prejudice that progressives tolerated before World War II:

The social and economic justice for this ordinance [to remove "white trade only" signs] has its very roots in the fact that general welfare of the Portland community will be enhanced through the eradication of a festering sore that reveals "second-class" citizenship and "Jim Crow" in its naked ugly form. The extension of service by all public places licensed by the city is a necessary step in this direction. ${ }^{399}$

While many racially exclusive progressives saw Japanese Americans as the race problem, civil rights progressives saw white supremacy as the real race problem. Of course anti-Japanese discrimination in employment, housing, and vandalism of the Rose City Japanese Cemetery continued until 1948 and possibly after. ${ }^{400}$

Studying the return of Japanese Americans to Oregon, especially the JACL's embrace of the Nisei Patriotism argument, allows us to broaden the focus of Japanese American history beyond the civil rights approach. The main factor that brought Portland's white community and its Japanese American community together was the argument that Nisei military service proved the loyalty of Japanese Americans. The argument led church groups and civic leaders to marginalize race-based nationalism and served as a keystone for Mike Masaoka’s legislative campaign for Issei

\footnotetext{
${ }^{398}$ Gus Solomon continued membership in the Oregon Committee of the Public Power League of America throughout 1945 and after. He served on the executive board until at least the end of 1945 along with wartime anti-Japanese organizers, such as Morton Tompkins of the Oregon Grange, and one of Walter Pierce's close associates Vernon Bull. Carl D. Thompson, Letter to Walter M. Pierce, 8 January 1945, Box 16, Folder 8, Pierce Papers, University of Oregon Archives.

399 "Local Groups Support Ban on Discrimination," Oregonian, 10 July 1950, p. 4.

400 “Minutes," Minutes, PDX JACL Collection.
} 
naturalization and the Evacuation Claims Act. Furthermore, the focus on military service was at the heart of the Portland JACL's postwar revival. ${ }^{401}$

The JACL's Nisei Patriotism argument was not without is limitations. To begin with, many Nisei questioned JACL leadership because of the JACL's wartime collaboration with federal authorities and the JACL's obsession with becoming the chief representative of the Japanese American community. Many Portland Nisei refused to participate in chapter activities because they saw the JACL as mainly interested in aiding the Issei. Furthermore, the Nisei patriotism argument itself marginalized draft resisters, repatriates, and other Nikkei who were unwilling to fight for a government that had incarcerated them. Because the legitimacy of Japanese Americans claims to their constitutional rights depended upon a narrative of military service, those that stood up the most for their constitutional rights, such as the Heart Mountain draft resisters, were those that were the most marginalized in the postwar. Unfortunately, accounts of the intense bitterness experienced by Japanese Americans who resisted American authorities rarely survive into the present day, making inclusion of their struggles difficult. ${ }^{402}$

Efforts by the Portland Citizen's Committee to Aid Relocation and the Portland Council of Churches were also limited in that they raised the public status of Japanese Americans from possible wartime enemy, but only to the limit status of provisional, honorary Americans. In housing, employment, and blood segregation,

${ }^{401}$ In 1950, the Japanese American community collected funds for a marble obelisk that now serves as the dominating feature of the Rose City Japanese Cemetery. "Monument Dedicated to Memory of 15 Nisei Servicemen Killed in War," Oregonian, 30 October 1950, p. 9.

${ }^{402}$ One of the most famous accounts of that bitterness exists in a fictional story of the return of a Japanese American draft resister to Seattle. See, John Okada, No-No Boy, (Seattle: University of Washington Press, 1976). 
Portland Nikkei faced the same discrimination as African Americans. Japanese

Americans were just one group aided by a wide variety of civic and religious groups

interested in proving the fair-mindedness of Portland on issues of race.

That is not to say that Japanese Americans successfully shed their transnational identity. Even before World War II, members of the Portland JACL sought to publicly distance itself from its Japanese heritage after tensions mounted between Japan and the U.S. ${ }^{403}$ However, though a connection to the $442^{\text {nd }}$ Regimental Combat Team helped Japanese Americans argue for their constitutional rights during and after World War II, the white community still saw them as transnational figures. For Mayor Earl Riley and Pierce, Japanese Americans were still basically equal to citizens of the Japanese Empire who constituted a racial threat to Oregon.

Some white Portlanders supported Japanese Americans out of a desire to protect people of Japanese descent, not out of a need to protect the rights of all American citizens. In 1942 pro-Japanese missionaries, like Emma Azalia Peet, had spoken out for fair treatment of Japanese Americans because her extended experience with Japanese in Japan. ${ }^{404}$ Marshal Dana, editor of the Oregon Journal, who gave an impassioned speech for tolerance of Japanese Americans in 1942, declined to

\footnotetext{
${ }^{403}$ Much more could be said about relations between the Japanese Chamber of Commerce (which was really just another name for the prewar Japan Society) and the JACL and other Nisei community organizations, especially their frank public meetings over citizenship, and the degree to which Japanese Americans should embrace their Japanese identity. See "JACL Town Meeting-Feb. 14, 1941," Town Meeting Reports, PDX JACL Collection.

${ }^{404}$ As mentioned in Chapter 2, Peet was the only individual to protest interment at the Portland Tolan Hearings in 1942. She was also a Methodist missionary to Japan for 25 years and returned to Oregon just a month prior to work with Japanese Americans in Portland and later worked with the Farm Security Adminstration to help Japanese Americans on work leave from Minidoka. In her career, she aided Japanese in America and abroad equally, practically ignoring the line of American citizenship. Robert Shaffer, "Opposition to Internment: Defending Japanese American Rigths During World War II," The Historian, Vol. 61 (1999), p. 608.
} 
participate in Caucasian advisory board letter writing campaigns in 1947 because he did not want to upset peace treaty negotiations between Japan and the U.S. ${ }^{405}$ Unlike European immigrants, Japanese Americans could not truly assimilate into the white majority. Visible otherness prevented it. As Portland JACL leader Howard Nomura put it, "we have Japanese faces and nothing can be done about it."406

That is not to say that sentiment towards Japanese Americans did not change over time. By 1948, Portland's shift towards civic nationalism led to the election of Dorothy McCullough Lee as Portland mayor. The change in leadership marked a shift in the city's official attitude towards people of Japanese ancestry. In 1950, a group of Nisei veterans and other Japanese American community leaders calling themselves the Japanese American Memorial League collected funds to erect a monument to Frank Hachiya and the fourteen other Nisei soldiers who died during World War II. Over one hundred Portland Nikkei attended the ceremony, proclaiming, in the words of Oregon Nisei Veterans leader Dr. George Y. Marumoto, that "They have earned the right for their families and themselves to share in the American way of life." Speaking at the funeral, Mayor Lee also attested to the importance of the Nisei soldiers' military service:

The one thing that these men might want us to do would be to attempt to live our lives as citizens of this great country in a way that carries out the spiritual values for which they died. With all deference to this monument, there could be no memorial, which could do justice to the sacrifice of these young Americans. ${ }^{407}$

405 "Summarized Report of the JACL Rally," JACL Activities circa 1941-1942, PDX JACL Collection. Marshall N. Dana, Letter to Toshi Kuge, 26 April 1948, Anti-Discrimination Committee, PDX JACL Collection.

406 "Nisei Placed in a Tough Spot," Oregonian, 8 December 1941, p. 9.

407 "Monument Dedicated to Memory of 15 Nisei Servicemen Killed in War," Oregonian, 30 October 1950 , p. 9. 
Lee's acceptance of the Nisei, as full-fledged Americans was a marked difference compared to Riley's calls for exclusion.

Lee's public gestures of friendship were not limited to Japanese Americans. In 1952, Lee accepted from Consul Masayuki Harigai two thousand cherry seeds as a symbolic gift from the school children of Japan. Edgar Smith, president of the Portland Chamber of Commerce, was also present at the gift ceremony, signaling that good relations with Japan were once again a chief interest to Portland businessmen. ${ }^{408}$ Individual accounts of housing discrimination and Sagie Nishioka's rebuff by the Oregon tax commission attest to continuing anti-Japanese sentiment in Portland. However the shift towards public acceptance of Japanese American constitutional rights by Portland officials and community leaders discouraged further anti-Japanese acts. Although the leadership of the Portland JACL may not have accomplished a seamless integration into postwar American life, the Nisei patriotism argument served as a powerful and positive point of contact between the white and Japanese American communities in the postwar.

This work provides only a glimpse into the issues of identity and visions of the future negotiated in Portland surrounding the status of Japanese Americans before and after internment. Although it is important to recognize that for Japanese Americans the return period between 1945 and 1948 was a time of recovery from the ideological and economic trauma of internment, the return affected more than just them. The return of

\footnotetext{
${ }^{408}$ By 1952, trade between Oregon and Japan had fully resumed. On the same day as the ceremony at least six ships were scheduled to depart Portland harbor with grain and other goods bound for Japan. "Japanese Amity Token Gratefully Taken," Oregonian, 4 December 1952, p. 18. "Daily Calendar of Ship Movements," Oregonian, 4 December 1952, p. 18.
} 
Japanese Americans sparked a public reevaluation among Portlanders of the place of ethnic minorities in American society. Most importantly debates around the return refuted, in terms of publicly acceptable discourse, the vision of Oregon as a white man's haven endangered by Asian immigration. Thus, the story of Japanese Americans' return to Portland is more than just a chapter in the history of an American minority group's struggle for acceptance. The return story highlights origins of civil rights coalitions and early postwar attempts, through the challenge of racially discriminatory laws and public education, to ease interracial tensions in Oregon. 
References

\section{$\underline{\text { Archival Sources }}$}

Governor Charles Sprague Papers, Oregon State Archives. (Sprague Papers)

Governor Earl Snell Papers, Oregon State Archives. (Snell Papers)

Japanese American Citizens League History Collection, Japanese American National Library.

"Japanese in Oregon”, Correspondence from files of Oregon Governors, Oregon Historical Society, Portland, Oregon, Microfilm \#9, Reel 1.

Minidoka Irrigator and Pacific Citizen articles, Densho Online Archive, Densho: Japanese American Legacy Project, Densho.org

Mizuta Scrapbook, George Mizuta, Microfilm 154, Oregon Historical Society Research Library.

Oregon Nikkei Legacy Center Research Library, Portland, Oregon.

Portland City Council Minutes, City of Portland Archives, Portland, Oregon.

Portland Japanese American Citizen's League Collection, Portland State University Archives. (PDX JACL Collection)

Portland, Oregon Young Women's Christian Association (YWCA) Collection 19012001, Lewis and Clark College Special Collections.

Walter Marcus Pierce Collection, University of Oregon Archives. (Pierce Papers).

\section{$\underline{\text { Primary Sources }}$}

“A Statement on the Japanese," Hood River Post No. 22 American Legion, Department of Oregon. Charlie Davis Collection, Oregon Nikkei Legacy Center Archive, Box 1 Folder 41.

"Advertisement for a Civil Liberties League Meeting," Commission on Wartime Relocation and Internment of Civilians Collection, Microfilm A7378, Reel 7, Box 7, Frame 244, Item 7743, University of Washington Special Collections.

“Aid Requested On Cemetery,” Oregonian, 15 August 1943. 
“An Appeal to Courage,” Minidoka Irrigator, 24 March 1945, p. 4.

“Anti-Japanese Question in Legislature," Oregon Voter, 16 December 1944, pp. 5-10.

“Anti-Jap Measures SJMs 8,9,” Oregon Voter, 6 March 1943, 3.

Barber, Lawrence “Japanese Due to Ship Home," Oregonian, 26 December 1945, p. 12.

Biddle, Francis, "Civil Liberties and the War," Address by Biddle before the Junior Bar Conference, Philadelphia, PA, 10 September 1940.

“Blood Donors List,” Portland Hi-Lites, 14 November 1946.

Burns, Ann Reed, "Japanese Coast Return 'Better Than Expected'," Oregonian, 10 February 1946, p. 14.

"California's Supreme Court Asked to Rule State's Alien Property Legislation Invalid," Pacific Citizen, 16 March 1945, p. 3.

“Carson Urges Internment of Japanese," Oregon Legionnaire, March 1942, 3.

“Churches Rap Legion Act,” Oregonian, 4 Dec 1944, 1.

“Civil Liberties League," Civil Liberties League 1942, Box 1, Japanese American Citizens League History Collection, Japanese American National Library Archives.

Considine, Bob, "MacArthur the Magnificent: The Defense of Bataan Starts," The Deseret News, 16 April 1942, p. 2.

“Crush Japs, Urges Head of Legion,” Oregonian, 19 August 1943, 1.

“Defeat of Memorials Aim of Church,” Minidoka Irrigator, 20 March 1943, 3.

Department of Justice, Press Release, 11 Dec 1941, Pierce Papers, Collection 68, Box 29, Folder 1.

Disaster Committee Report, Portland-Multnomah County Chapter, American Red Cross, "Vanport City Flood," Series 6 Vanport City, Subseries 1 The Flood 30 May 1948, Vanport Records, 1946-1973, Portland State University Special Collections.

Evacuess to be Aided by Rose City Group," Minidoka Irrigator, 17 February 1945, 2. 
“Exclusion Act Repeal Urged By Portland Groups," Minidoka Irrigator, 31 July 1943, p. 2.

“Exclusion of Japanese Topic of Oregon Paper,” Minidoka Irrigator 24 March 1945, 1.

Fair Play Committee Bulletin, "We Should Know," in Gail M. Nomura, et, al, eds. Frontiers of Asian American Studies, (Washington State UP, 1989).

Fistere, Harold S., "Analysis of the Final Report," Northwest Area, WRA, 2 May 1946, Microfilm 9, Reel 2, Oregon Historical Society Research Library.

Forden, Eleanor N..“Stands by Local Japanese,” Oregon Journal, 12 March 1945.

"Former Governor of Oregon Urges Ousting of Aliens," Minidoka Irrigator, 1 May 1943, p. 2.

"Frank Hachiya: He was American at Birth—and at Death," Oregonian, 20 May 1945.

"From Camp to College: The Story of Japanese American Student Relocation," Philadelphia, PA: National Japanese American Student Relocation Council, 1945. Tambara Collection, 53/77 \#2002.26, Oregon Nikkei Legacy Center Archives.

"Front Line Soldiers Rap Hood River Legion Act," Oregonian, 29 January 1945, Section 2, p. 3.

“Gifford Head of K. K. K.," Oregon Voter, 25 March 1922, p. 6.

"Gresham Groups Organizes to Oppose Return of Japs," Oregon Journal, 28 November 1944.

“Group Organizing Against Japanese,” Oregonian, 28 November 1944.

Hachiya, Ted, Oral History, transcript, Oregon Nikkei Legacy Center Research Library.

Heard, Barttlet B., Letter to all YWCA Associations in the Western Defense Command, Personnel: Correspondence, Contracts, News Articles 1940-50, Box 7, Folder 28, Oregon YWCA Collection, Lewis and Clark College Special Collections.

“JACL Meeting Slated Wednesday,” Minidoka Irrigator, 15 May 1943, p. 2.

“JACL Town Meeting" 14 February 1941, Town Meeting Reports, PDXJACL Collection. 
“JACL Will Assist with Naturalization Papers," Portland Hi-Lites, 23 October 1946.

“Jap Rights Win Defense,” Oregonian, 28 February 1945, p. 5.

"Japanese Association of Oregon," Japanese Association of Oregon, Community Organization Files, Oregon Nikkei Legacy Center Research Library.

"Japanese Internees in Missoula from the Portland, OR Area," Japanese Association of Oregon, Community Organizations, Oregon Nikkei Legacy Center Research Library.

Kimmerling, Constance, "Report of the Welfare Section," 28 Feb 1945, Minidoka Relocation Center, Introduction, Section A, Japanese American Evacuation and Resettlement Records, 1930-1974. Bancroft Library MSS 67/14.

“Leaders Talk of Alien Peril; Oregon Dangers Discussed,"Oregonian, 27 February $1942,15$.

Lesowski, Linda, "Vanport Remembered," Oregonian, 21 May 1978, Northwest Magazine Section, p. 10.

Linville, Clyde W., “To all Relocatees,” 31 January 1946, PDX Collection

“Masaoka Voices Plea for Unity,” Minidoka Irrigator, 27 January 1943, p. 1.

Matsushima, Yoji, Oral History, transcript, Interviewed by Valerie Otani, 2009, Oregon Nikkei Legacy Center Research Library,

"Matsushima, Umata," FBI Arrests, Subject Files, Oregon Nikkei Legacy Center Research Library.

Minoru, Yasui, letter to the editor, Minidoka Irrigator, 1 May 1943, p. 4.

Minutes: Board of Director's Meeting, Young Women's Christian Association, Portland, OR, May 12, 1942, p 2. Box 9A, Folder 1, Lewis \& Clark College Special Collections and Archives.

"Minutes: Executive Committee," Portland Chamber of Commerce, June 3, 1943, Mss 686-2, Folder 6, Oregon Historical Society Research Library.

Minutes, Board of Directors YWCA 12 December 1944 and 16 January 1945, 9B-1, Oregon YWCA Collection. 
"Minutes of the Portland Chapter of the JACL, 1930-1939," Sakai Collection, Oregon Nikkei Legacy Center Research Library.

"Minutes of the Twenty-Fifth Department of Oregon American Legion Convention, Portland, OR, August 20-21, 1943" page 16, Mss 1511, Box 2, Folder 16, Oregon Historical Society Research Library.

Miyamoto, Frank, Oral History, Interview III, Segment 16, Densho: the Japanese American Legacy Project, online archive, ID\# denshovh-mfrank-03-0016, densho.org.

“Move To Deport Japanese Rapped by Salem Paper," Minidoka Irrigator, 20 March 1943, p. 3.

Neuberger, Richard L., "Housing Dispute in Aftermath of the Vanport Disaster," New York Times, 11 July 1948.

"Nisei Accepts Job in Salem: Veteran to Become Junior Accountant," Oregonian, 3 April 1951, p. 11.

"Nisei Choose Other Areas," The Oregonian, 9 March 1945, p. 7.

"Nisei Placed in a Tough Spot," Oregonian, 8 December 1941, p. 9.

"Nisei Praise WRA Activity: Aid in Evacution Days Recalled," Oregonian, 27 April 1946, p. 7.

“N. Y. Legion Will Accept 16 Soldiers,” Oregon Journal, 23 December 1944.

“Officials Rap City On Nisei Policy,” Oregonian, 21 July 1945, p. 4.

“Opposition of National JACL to All Test Cases Explained by Masaoka," Ikeda Collection, Densho Online Archive: denshopd-p72-00039.

Oregon Commonwealth Federation, pamphlet, "And Now - the Truth About the Oregon Commonwealth Federation," Pierce Collection, University of Oregon Archives, Collection 68, Box 20, Folder 1.

Oregon House and Senate Journal, 1945.

“Oregonians Eye Issue Debatably,” Oregonian, 18 December 1944, p. 1.

“Oregon's Citizens Rally at Japanese Challenge to America in Pacific," Oregonian, 8 Dec 1941, p. 6. 
“Our Japanese Problem,” Oregonian, 3 December 1944, p. 18.

“Papers Recalled for 'Race’ Group,” Oregonian, 11 January 1945, p. 7.

"Pierce Slaps at Japanese: Ex-Governor Says Race Doesn’t Fit," 10 February 1945, p. 4.

Pierce, Walter M. "Civilization Must Win Another Contest: The Japanese Onslaught," Congressional Record, November 19, 1942, 49893-283, p 6830-6836.

---“Some Wartime Problems," speech given in Albany, OR 9 February 1943. Walter M. Pierce Papers, Collection 68, University of Oregon Archives, Box 74, Folder 5.

--- speech, “The Power Fight” 1938, Pierce Papers, Box 10, Folder 14.

"Pertinent Facts About Relocation Centers and Americans of Japanese Ancestry," War Relocation Authority, 23 Nov 1944. Ikeda Family Collection, Densho Archives. Online denshopd-p72-00041.

"Portland Chapter JACL Activities," 1946-1948, PDX Minutes, PDX JACL

\section{Collection.}

Portland City Club Bulletin,1 Dec 1944.

Portland City Council Minutes, Portland City Archives.

“Portland Minister Threatened for Favoring Japanese," Minidoka Irrigator, 9 December 1944, p. 2.

Portland Realty Board, "Constitution and By-Laws, Code of Ethics," 7 April 1948, Mss 1511 Portland Realty Board, Box 35 Folder 6, Oregon Historical Society Research Library.

“Portlanders Here for Y-Tea,” Minidoka Irrigator, 10 October 1942, p. 3.

"Private Hachiya, American,” New York Times, 17 February 1945, p. 12.

"Protests Rise as Japanese Try to Regain Land," Oregonian, 30 December 1944.

“Race Feeling Under Attack," Oregonian, 4 December 1944, p. 11.

"Race Prejudice Expressed in Resolutions, Oregon Voter, 19 June 1943.

“Race Relations Clinic,” Box 3, Folder 3, Snell Papers, Oregon State Archives. 
“Racial Bias To Be Fought," Oregonian, 9 May 1943, Section 3, p. 8.

"Relocation Authorities Amazed By Splendid Reception Given Evacuees Returning to Oregon," Pacific Citizen, 16 February 1946, p. 2.

"Relocation Benefits Told," Oregonian, 15 January 1945, p. 5.

"Resettlement Bulletin: Northwest Area," Coll 15, 2009.15, Oregon Nikkei Legacy Archives.

"Return to Coast Opposed by $31 \%$ of Coast Residents, Gallup Pole Survey Reveals," Minidoka Irrigator, 6 January 1943, p. 4.

"Resolutions in the Senate," Oregon House and Senate Journal. 1943, pp. 378-379.

“Roger Baldwin Says Rights Not Seriously Infringed," Minidoka Irrigator, 2 Dec 1944, p. 1.

"Sailor's Union of the Pacific, Japanese and Korean Exclusion League," Minutes, 10 January 1910, Microfilm 59, Oregon Historical Society Research Library.

“Service Men Tolerant," Oregonian, undated March 1945, Mizuta Scrapbook, George Mizuta, Microfilm 154, Oregon Historical Society Research Library.

"Sheriff Heads Off Riot By Preventing Pacifists From Honoring Jap Dead," Oregonian, 15 August 1943, p. 17.

Snell, Earl, Statement to Legislature, undated, Box 2, Folder 4, Snell Papers, Oregon State Archives.

Snell, Earl, "Statement about Oregon Alien Land Law, February 1945," Snell Papers Box 3, Folder 3.

Solomon, Gus J, Oral History, Oregon Jewish Museum.

Tajiri, Larry, "Reviving a Dead Letter," Pacific Citizen, 16 February 1946, p. 4.

Takeoka, Tom, e-mail to Rebecca Patchett of Oregon Nikkei Legacy Center, Local Figure Files, Takeoka, Daiichi, Oregon Nikkei Legacy Center Research Library.

Tambara, Kimi “An Appeal to Courage,” Minidoka Irrigator, 24 March 1945, p. 4. 
Tambara, Kimi "Special Memorial Day Rites Honor Oregon Dead," The Oregon News, May 31, 1946, p. 1.

“The Challenge," Oregonian, 19 December 1944, p. 6.

“The Japanese Peril,” Postmaster's Gazette, February 1944, pp. 31, 33.

“Those Highly Sensitive Japs,” Oregonian, 6 February 1943.

"Two Given Indefinite Leaves for Work, First on Record," Minidoka Irrigator, 24 Oct 1942, p. 1.

The Urban League of Portland, "Second Annual Report—1946," Organizations: Other Womens Organizations, Pamphlets, Brochures, Newsletters, 1940s+, Box 7, Folder 16, Papers of the Young Women's Christian Association, 1901-2001, Lewis and Clark College Special Collections and Archives.

U.S. Congress. House. $77^{\text {th }}$ Congress, $2^{\text {nd }}$ Sess. "Findings and Recommendations on Evacuation of Enemy Aliens and Others from Prohibited Zones" Select Committee Investigating National Defense Migration, Fourth Interim Report, May 1942, House Report No 2124.

U.S. Congress. House. $77^{\text {th }}$ Congress, $2^{\text {nd }}$ Sess. "Preliminary Report and Recommendations on Problems of Evacuation of Citizens and Aliens from Military Areas" Select Committee Investigating National Defense Migration, March 19, 1942, House Report No 1911.

“War Department Plans Completed,” Minidoka Irrigator, 29 January 1943, p. 1.

War Relocation Authority, "Pearl Harbor and the Witch Hunt," Northwest Area Final Report of the Reports Officer, circa 1946, report number unknown, "Japanese in Oregon", Correspondence from files of Oregon Governors, Oregon Historical Society, Portland, Oregon, Microfilm \#9, Reel 2.

War Relocation Authority, Relocation Program, (Washington D. C., 1946).

"War Secretary and Other Legionnaires Condemn Blacklisting of Loyal Nisei," Oregonian, 15 December 1944, 1.

“Women Oppose Jap Deportation," Oregonian, 5 March 1943, p. 5.

Worden, William L. "The Hate That Failed," Saturday Evening Post, 4 May 1946.

Woods, Jim, “Jap Leader Here Paid By Tokyo,” Oregon Journal. 30 March 1942, p. 1. 
Yasui, Homer, "Santa Fe Internees," Internment Camps - Justice Dept., INS — Santa Fe NM, Subject Files, Oregon Nikkei Legacy Center Research Library.

\section{$\underline{\text { Secondary Sources }}$}

Azuma, Eiichiro, “A History of Oregon's Issei, 1880-1952,” Oregon Historical Quarterly, Winter 1993-1994, pp. 315-368.

---, Between Two Empires: Race, History, and Transnationalism in Japanese America, (Oxford: Oxford UP, 2005).

Bangarth, Stephanie, Voices Raised in Protest: Defending North American Citizens of Japanese Ancestry, 1942-1949, (Vancouver, UBC Press, 2008).

Bone, Arthur H., Oregon Cattleman/Governor, Congressman: Memoirs and Times of Walter M. Pierce, (Portland, OR: Oregon Historical Society Press, 1981).

Brooks, Charlotte, Alien Neighbors, Foreign Friends: Asian Americans, housing, and the Transformation of Urban California, (Chicago: University of Chicago Press, 2004).

Brooks, Cheryl A., "The Politics of Forgetting: How Oregon Forgot to Ratify the Fourteenth Amendment," Journal of Oregon Humanities Fall/Winter 2006, pp. 46-54.

Buck, Amy K., "Alien Land Laws: The Curtailing of Japanese Agricultural Pursuits in Oregon," Masters Thesis, Portland State University, 1999.

Chin, Frank, Born in the USA: A Story of Japanese America, 1891-1947, (Rowman and Littlefield Publishers: Oxford, 2002).

Chou, Chih-Chieh, "Critique on the Notion of Model Minority: An Alternative Racism to Asian American?" Asian Ethnicity, Vol. 9, No. 3, October 2008, p. 219-229.

Cox, Ted W., The Toledo Incident of 1925: Three Days That Made History in Toledo, Oregon, (Old World Publications: Corvallis, Oregon, 2005).

Dempster, Brian Komei Ed., Making Home From War: Stories of Japanese American Exile and Resettlement, (Berkeley: Heyday, 2011).

Dower, John W., War Without Mercy: Race and Power in the Pacific War, (New York: Pantheon, 1986). 
Dusenbery, Verne, "The Japanese Problem in Oregon," Oregon Law Review, 24 (1944-1945), pp. 208-219.

Eisenberg, Ellen, “'As Truly American as Your Son': Voicing Opposition to Internment in Three West Coast Cities," Oregon Historical Quarterly, Winter 2003, pp. 542-565.

Eisenberg, Ellen, The First to Cry Down Injustice?: Western Jews and Japanese Removal During World War II, (Lexington Books: Lanham, MD: Lexington Books, 2008).

Fryer, Heather, Perimeters of Democracy: Inverse Utopias and the Wartime Social Landscape in the American West, (Lincoln, NE: University of Nebraska Press, 2010).

Galiskey, Anne Francis, "Repressive Populsim and the Internment of Japanese Americans of the Pacific Northwest," Master's Thesis, Portland State University, 2003.

Gayne, Mary K., "Japanese Americans at the Portland YWCA,” Journal of Women's History 15, No 3, pp. 197-203.

Gerstle, Gary, American Crucible: Race and Nation in the Twentieth Century, (Princeton: Princeton UP, 2001).

Girdner, Audrie and Anne Loftis, The Great Betrayal: The Evacuation of the Japanese Americans During World War II, (London: MacMillan, 1969)

Hansen, Arthur A., " Protest-Resistance and the Heart Mountain Experience: The Revitalization of a Robust Nikkei Tradition," in Mike Macky ed., A Matter of Conscience: Essays on the World War II Heart Mountain Draft Resistance Movement, (Western History Publications: Powell, Wyoming, 2002).

Hayashi, Brian Masaru, Democratizing the Enemy: The Japanese American Internment, (Princeton, NJ: Princeton UP, 2004).

Horowitz, David A., Inside the Klavern: The Secret History of a Klu Klux Klan of the 1920s, (Carbondale, IL: Southern Illinois UP, 1999).

Jacobsen, Matthew, Whiteness of a Different Color: European Immigrants and the Alchemy of Race, (Cambridge: Harvard UP, 1998).

Johnson, David A., Founding the Far West: California, Oregon, and Nevada, 18401890, (Berkeley: University of California Press, 1992). 
Kashima, Tetsuden, "Japanese American Internees Return, 1945 to 1955:

Readjustment and Social Amnesia," Phylon, Vol 41, No. 2, (2 ${ }^{\text {nd }}$ Qtr., 1980), pp. 107-115.

Kashima, Tetsuden, Judgement Without Trial: Japanese American Imprisonment During World War II, (Seattle: University of Washington Press, 2003).

Kazuo Ito, Issei: A History of Japanese Immigrants in North America, Trans. Shinichiro Nakamura and Jean S. Gerard, (Japan: Japan Publishing, 1973).

Kessler, Lauren, Stubborn Twig: Three Generations in the Life of a Japanese American Family, (Corvallis, OR: Oregon State University Press, 2005).

Lake, Marylin and Henry Reynolds, Drawing the Global Colour Line: White Men's Countries and the International Challenge of Racial Equality, (Cambridge: Cambridge UP, 2008).

Lee, Erika, "The 'Yellow Peril' and Asian Exclusion in the Americas," The Pacific Historical Review Vol. 76, Issue 4, pp. 537-562.

Lim, Deborah K., "Research Report Prepared for Presidential Select Committee on JACL Resolution \#7,” 1990, No-Nos, Subject Files, Oregon Nikkei Legacy Center Research Library.

MacColl, E. Kimbark, The Growth of a City: Power and Politics in Portland, Oregon 1915 to 1950, (Portland, OR: The Georgian Press Co., 1979).

McCoy, Robert R., “The Paradox of Oregon's Progressive Politics: The Political Career of Walter Marcus Pierce," Oregon Historical Quarterly 110.3 (Fall 2009), pp. 390-416.

Murray, Alice Yang, Historical Memories of Japanese American Internment and the Struggle for Redress, (Stanford: Stanford UP, 2008).

Nakata, Deena Kei, The Gift: The Oregon Nikkei Story...Retold, (Oregon: D.K. Nakata, 1995).

Okihiro, Gary Y. Common Ground: Reimagining American History, (Princeton, NJ: Princeton UP, 2001).

Pearson, Rudy, "A Menace to the Neighborhood: Housing and African Americans in Portland, 1941-1945," Oregon Historical Quarterly, Vol. 102, No. 2, (Summer 2001), pp. 158-179.

Pfaelzer, Jean, Encyclopedia of U. S. Labor and Working-Class History, Vol. 1, Eric 
Arnesen Ed., (New York: Routledge, 2007).

Pursinger, Marvin Gavin, Oregon's Japanese in World War II: A History of Compulsory Relocation, Dissertation, University of Southern California, 1961.

Robbins, William G. “The Wartime Correspondence of Monroe Sweetland and Lillie Megrath Sweetland," Oregon Historical Review, Vol 110, No 1, (2010), pp. 64-82.

Robinson, Greg, A Tragedy of American Democracy: Japanese Confinement in North America, (New York: Columbia UP, 2009).

Rodgers, Daniel T., "In Search of Progressivism," Reviews in American History 10, (1982), pp. 113-132.

Roxworthy, Emily, The Spectacle of Japanese American Trauma: Racial Performivity and World War II, (Honolulu: University of Hawaii Press, 2008).

Saxton, Alexander, The Rise and Fall of the White Republic: Class Politics and Mass Culture in Nineteenth-Century America, (London: Verso, 1990).

--- The Indispensable Enemy: Labor and the Anti-Chinese Movement in California, (Berkeley: University of California Press, 1995).

Schneider, William H. "Blood Transfusion Between the Wars," Journal of the History of Medicine and Allied Sciences, Vol. 50, Issue 2, pp. 187-224.

Simpson, Caroline Chung, An Absent Presence: Japanese Americans in Postwar American Culture, 1945-1960, (Durham, NC: Duke UP, 2001).

Spickard, Paul R., “The Nisei Assume Power: The Japanese Citizens League 19411942," Pacific Historical Review 25, No 2 (May 1983), pp. 147-174.

Stein, Harry H., Gus J. Solomon: Liberal Politics, Jews, and the Federal Courts, (Portland, OR: Oregon Historical Society Press, 2006).

Stevens, Beatrice, Free and Equal: The Japanese Americans in Oregon, (Portland, OR, 1945).

Tamura, Linda, The Hood River Issei: An Oral History of Japanese Settlers in Oregon's Hood River Valley, (Urbana, IL: University of Illinois Press, 1993).

Tateishi, John, And Justice for All: An Oral History of the Japanese American Detention Camps. (Seattle, WA: University of Washington Press, 1999). 
Taylor, Quintard, The Forging of a Black Community: Seattle's Central District from 1870 Through the Civil Rights Era, (Seattle: University of Washington Press, 1994).

Thomas, Dorothy Swaine The Salvage: Japanese American Evacuation and Resettlement, (Berkeley: UC Berkeley Press, 1952).

War Agency Liquidation Unit, People in Motion: The Postwar Adjustment of the Evacuated Japanese Americans, (Washington D.C.: U.S. Government Printing Office, 1947).

Yasui, Barbara, “The Nikkei in Oregon, 1843-1940," Oregon Historical Quarterly 76 (September 1975), pp. 224-257. 